Marcia Cristina Castanhari Mandelli

\title{
Condições de trabalho e morbidade referida para distúrbios osteomusculares em catadores de materiais recicláveis
}

\author{
Dissertação apresentada à Faculdade de \\ Medicina da Universidade de São Paulo \\ para a obtenção do título de Mestre em \\ Ciências \\ Departamento de Medicina Preventiva \\ Orientador: Prof. Dr. Nelson da Cruz \\ Gouveia
}

(Versão corrigida. Resolução CoPGr 6018/11, de 1 de novembro de 2011. A versão original está disponível na Biblioteca da FMUSP)

São Paulo 
Marcia Cristina Castanhari Mandelli

\title{
Condições de trabalho e morbidade referida para distúrbios osteomusculares em catadores de materiais recicláveis
}

\author{
Dissertação apresentada à Faculdade de \\ Medicinada Universidade de São Paulo \\ para a obtenção do título de Mestre em \\ Ciências
}

Departamento de Medicina Preventiva Orientador: Prof. Dr. Nelson da Cruz Gouveia

(Versão corrigida. Resolução CoPGr 6018/11, de 1 de novembro de 2011. A versão original está disponível na Biblioteca da FMUSP)

São Paulo 


\section{Dados Internacionais de Catalogação na Publicação (CIP)}

Preparada pela Biblioteca da

Faculdade de Medicina da Universidade de São Paulo

Creprodução autorizada pelo autor

Mandelli, Marcia Cristina Castanhari Condições de trabalho e morbidade referida para distúrbios osteomusculares em catadores de materiais recicláveis / Marcia Cristina Castanhari Mandelli. -- São Paulo, 2017.

Dissertação(mestrado)--Faculdade de Medicina da Universidade de São Paulo.

Programa de Medicina Preventiva. Orientador: Nelson da Cruz Gouveia.

Descritores: 1.Catadores 2.Reciclagem 3.Fatores de risco 4.Condições de trabalho 5.Dor musculoesquelética 6.Distúrbios osteomusculares relacionados ao trabalho

USP/FM/DBD-094/17 


\section{DEDICATÓRIA}

Dedico esta dissertação aos catadores de materiais recicláveis, com os quais passei por momentos de aprendizados valiosos.

Ao meu querido esposo 


\section{AGRACEDIMENTOS}

Aos meus pais por mostrar os valores imprescindíveis para seguir meu caminho.

Ao meu esposo Luís Roberto de Souza que tanto me incentiva a estudar com veemência.

Ao meu orientador Prof. Nelson Gouveia, que me proporcionou inúmeros momentos de aprendizado e pela paciência comigo.

A Dra.Gisele Mussi que me conduziu em todos os momentos deste trabalho dos assuntos pertinentes ao seu conhecimento.

A Profa Dra. Sylmara-Dias que despertou as idéias para os encontros e reuniões com os catadores, que também me ensinou de forma agradável e colaborou com seus escritos para que eu entendesse melhor do assunto.

A todos do Departamento de Medicina Preventiva que se mostraram tão receptivos nas minhas solicitações. Em especial o Ivaldo, Mirian, Tiago e a Ruth do setor de informática que me proporcionaram a vivência dos ensinamentos e me atenderam com prontidão por inúmeros momentos, a Lilian e a Goreth da secretaria pela atenção, ao senhor Jóca da gráfica pelo bate-papo, demonstrando sabedoria de vida e aos docentes pelos vários diálogos científicos que foram abrindo as frestas da minha janela.

Aos alunos Mariana Maleronka que deu a idéia inicial de trabalhar com os catadores, aos que me socorreram com seus saberes, Felipe Nascimento, Cleiton Fiorio, Juliana Viscondi e Ana Loch, e que também dêmos muitas risadas. 
A Rita esposa do Felipe por toda sua atenção e correções, as bibliotecárias Valéria e Isabel.

Ao Mateus Mendonça, da empresa Giral, que fez um respeitável trabalho com os catadores, escancarou suas portas para nos receber e foi um grande parceiro para realização dos folders de orientações para os catadores, sem ele não seria possível a realização desse material.

Ao Movimento Nacional dos Catadores de Materiais Recicláveis, em especial o Roberval Prates, sem ele não daríamos os primeiros passos dessa pesquisa.

A Rede Catasampa, em especial a Sandra que nos ajudou a procurar o universo dos catadores de cooperativas em São Paulo.

Aos Catadores de Materiais Recicláveis que com seus braços abertos me receberam em todos os momentos, os quais compartilharam inúmeras vivências e trajetórias de vida.

E não iria deixar de agradecer a minha cachorra Brigithe de 18 anos, mostrouse companheira em todas as horas, deixo o meu eterno amor. 


\section{Normatização adotada}

Esta tese está de acordo com as seguintes normas, em vigor no momento desta publicação:

Referências: adaptado de International Committee of Medical Journals Editors (Vancouver).

Universidade de São Paulo. Faculdade de Medicina. Serviço de Biblioteca e Documentação. Guia de apresentação de dissertações, teses e monografias. Elaborado por Anneliese Carneiro da Cunha, Maria Julia de A. L. Freddi, Maria F. Crestana, Marinalva de Souza Aragão, Suely Campos Cardoso, Valéria Vilhena. 3a ed. São Paulo: Divisão de Biblioteca e Documentação; 2011.

Abreviaturas dos títulos dos periódicos de acordo com List of Journals Indexed in Index Medicus. 



\section{SUMÁRIO}

Listas

Resumo

Summary

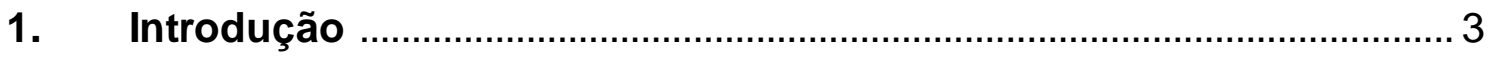

1.1 A reciclagem em seus aspectos socioambientais e a saúde dos catadores

1.2 Resíduos sólidos ......................................................................... 12

1.2.1Classificação dos resíduos sólidos........................................ 13

1.2.2 Geração dos Resíduos Sólidos ............................................ 14

1.2.3 Coleta seletiva de resíduos sólidos .........................................16

1.2.4 Disposição dos resíduos sólidos .......................................... 19

1.3 Cooperativas de materiais recicláveis ........................................... 21

1.3.1Aspectos da Organização ..................................................... 21

1.3.2 Galpão, Cooperativa ou Central de Triagem - Estrutura

Física e Seus Componentes ................................................. 24

1.4 Descrição dos catadores de materiais recicláveis.........................26

1.4.1 O reconhecimento do catador como profissão .....................26

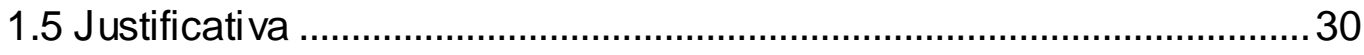

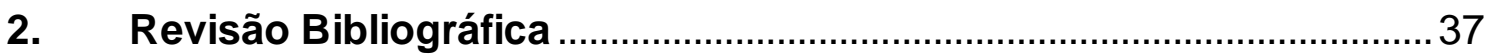

2.1 Diretrizes da Política Nacional em favor do catador .......................37

2.2 Saúde e Segurança em Cooperativas de Triagem.......................... 38

2.3. Os catadores e os riscos no ambiente de trabalho ........................43 43

2.4. Produção do catador como força de trabalho ................................46

2.5. Estudos de Morbidade Osteomuscular em Catadores de Materiais

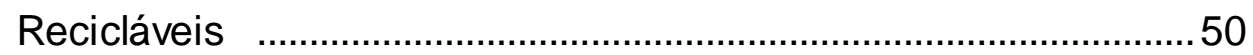

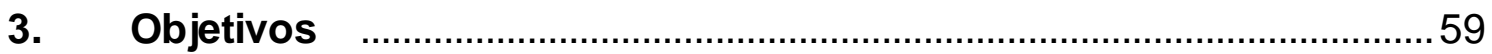

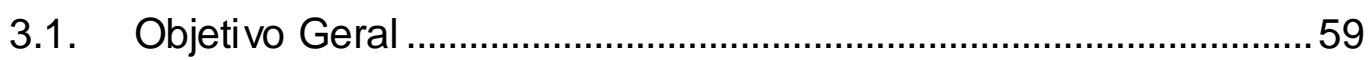

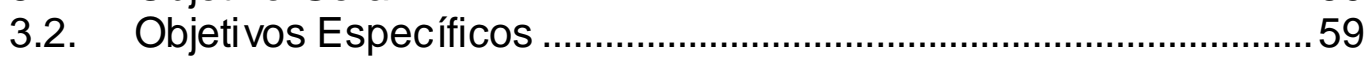

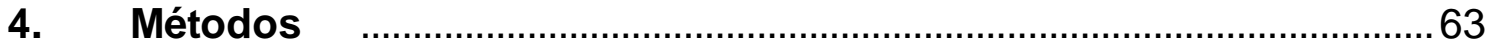

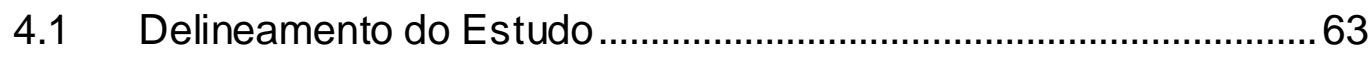

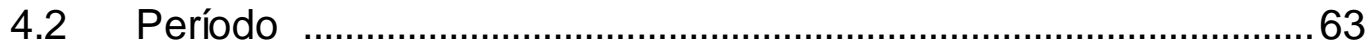

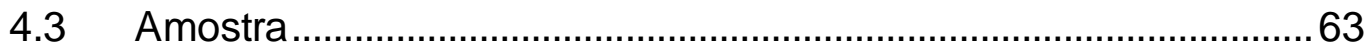

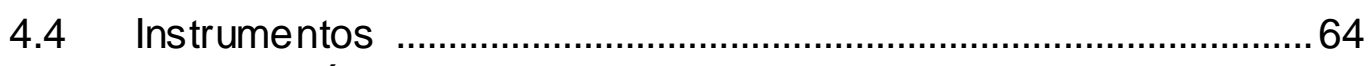

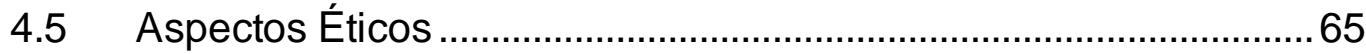




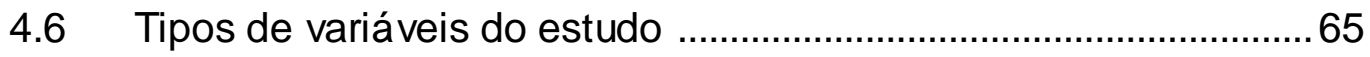

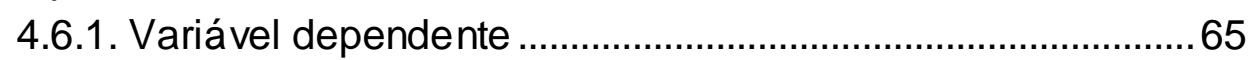

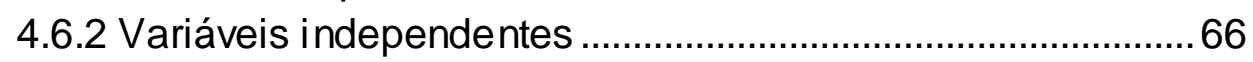

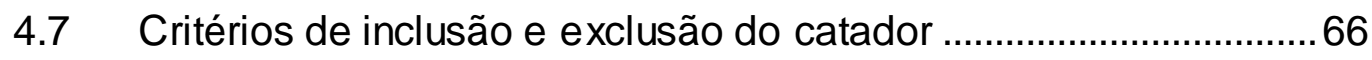

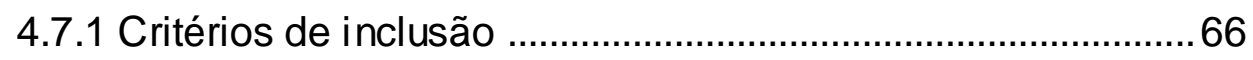

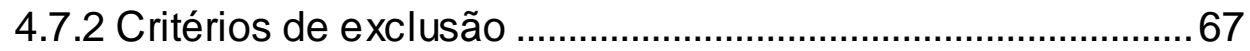

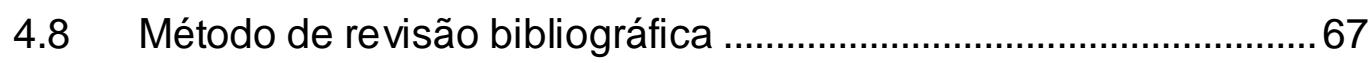

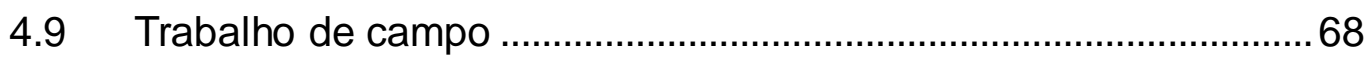

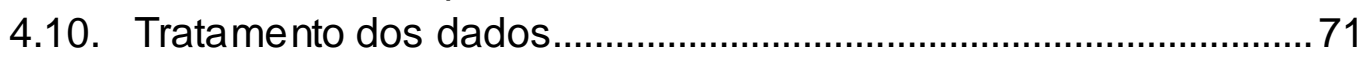

4.10.1 Consistência dos dados ......................................................71

4.10.2. Análise dos dados............................................................... 71

5. Resultados

5.1. Descrição da organização das Cooperativas estudadas................77

5.2 Descrições das características sociodemográficas ..........................84

5.3. Descrição das condições de trabalho ………………………........ 85

5.4. Descrições da organização e fator psicossocial do trabalho .........88

5.5. Descrição da dor/desconforto osteomuscular nos 12 meses que antecederam ao estudo em relação ao processo de trabalho 90

5.6. Análise Univariada ........................................................................93

5.7. Modelo de Análise Múltipla ................................................................99

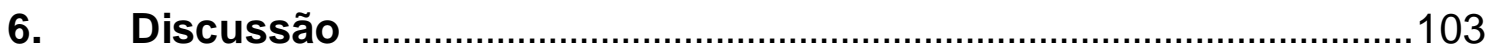

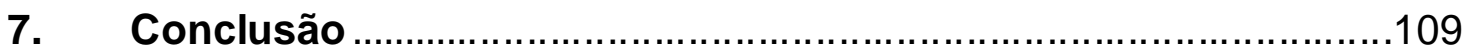

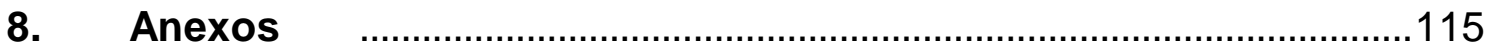

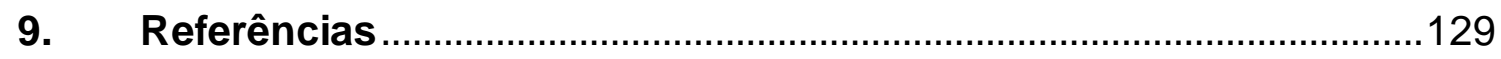




\section{LISTA DE ABREVIATURAS}

ABNT Associação Brasileira de Normas Técnicas

ABRELPE Associação Brasileira de Empresas de Limpeza Pública e Resíduos Especiais

AMLURB Autoridade Municipal de Limpeza Urbana

BNDES Banco Nacional de Desenvolvimento Economico e Social

CBO Classificação Brasileira de Ocupações

CEADEC Centro de Estudos ao Apoio ao Desenvolvimento Emprego e Cidadania

CETESB Companhia de Tecnologia Ambiental do Estado de São Paulo

CRAS Centro de Referência de Assistência Social

CT Cooperativa de Triagem

DORT Distúrbios Osteomusculares Relacionados ao Trabalho

EcoUrbis EcoUrbis Ambiental S. A.

EPIs Equipamentos de Proteção Individual

FUNASA Fundação Nacional de Saúde

IBGE Instituto Brasileiro de Geografia e Estatística

INSS Instituto Nacional de Seguridade Social

IPEA Instituto de Pesquisa Econômica Aplicada

Kg Kilograma

LER Lesões Esforços Repetitivos

LOGA Logística Ambiental de São Paulo S. A.

MMA Ministério do Meio Ambiente

MMII Membros inferiores

MMSS Membros superiores

MNCR Movimento Nacional dos Catadores de Materiais Recicláveis

MR Material reciclável

MRs Materiais recicláveis

MS Ministério da Saúde

MTE Ministério do Trabalho e Emprego 
$\mathrm{NIOSH}$ Instituto Nacional de Segurança e Saúde Ocupacional

NBR Norma Brasileira de Resíduos

NR Norma Regulamentadora

NS Resíduos sólidos

OMS Organização Mundial de Saúde

PAC Plano de Aceleração de Crescimento

PEV Pontos de Entrega Voluntária

PGIRS Plano de Gestão Integrada de Resíduos Sólidos

PMGIRS Plano Municipal de Gestão Integrada de Resíduos Sólidos

PNRS Política Nacional de Resíduos Sólidos

QNSO Questionário Nórdico de Sintomas Osteomusculares

REEE Resíduos de Equipamentos Eletro Eletronicos

RMSP Região Metropolitana de São Paulo

RS Resíduos Sólidos

RSS Resíduos Sólidos Secos

RSU Resíduos Sólidos Urbanos

SciELO Scientific Electronic Library Online

SENAES Secretaria Nacional de Economia Solidária

SESMT Serviços Especializados em Engenharia de Segurança e em Medicina do Trabalho

ST Saúde do trabalhador 


\section{LISTA DE QUADROS}

Quadro 1. Classificação Ocupacional e Funções dos Catadores de Materiais Recicláveis 27

Quadro 2. Variáveis independentes e dependentes e suas características de respostas 73

Quadro 3. Principais características das cooperativas de materiais

recicláveis da RMSP 81 


\section{LISTA DE TABELAS}

Tabela 1. Distribuição das variáveis sociodemográficas dos catadores estudados, 2015 .84

Tabela 2. Variáveis da história laboral e das informações sobre as atividades no trabalho, 2015 .85

Tabela 3. Percepção das condições de trabalho, 2015. .87

Tabela 4. Percepção da organização do trabalho e a satisfação em pertencer à categoria profissional, 2015. .89

Tabela 5. Distribuição de dor/desconforto osteomusculares, 2015. .91

Tabela 6. Dor/desconforto osteomusculares nos últimos 12 meses segundo características sociodemográficas e história laboral, 2015 .94

Tabela 7. Dor/desconforto osteomusculares nos últimos 12 meses segundo características das condições de trabalho, 2015. .96

Tabela 8. Dor/desconforto osteomusculares nos últimos 12 meses segundo características organização do trabalho e fator psicossocial, 2015 .98

Tabela 9. Variáveis que compõem o modelo final da regressão logística .99 


\section{RESUMO}

Mandelli MCC. Condições de trabalho e morbidade referida para distúrbios osteomusculares em catadores de materiais recicláveis [Dissertação]. São Paulo: Faculdade de Medicina, Universidade de São Paulo; 2017.

INTRODUÇÃO: A urbanização tem sido acompanhada por um crescente aumento no volume e na diversidade de resíduos sólidos produzidos. O reaproveitamento desses resíduos vem sendo feito desde o início do século XX, inicialmente pela figura do "velho garrafeiro", até que em 2003 ocorre o reconhecimento da profissão do "catador de materiais recicláveis" na Classificação Brasileira de Ocupações. O problema ambiental decorrente da geração e do descarte de resíduos fez com que fosse instituída a Política Nacional de Resíduos Sólidos, sendo que entre suas diretrizes há o estimulo à participação do catador na cadeia produtiva da reciclagem.

Não obstante a ocorrência de avanços nas condições de trabalho dos catadores persistem exposições penosas às cargas biomecânicas, tais como esforços físicos, posições viciosas e movimentos repetitivos. Adicionalmente, a organização do processo produtivo e o modo com que os catadores desenvolvem suas tarefas, são situações que predispõem a riscos e danos à saúde.

OBJETIVO: Identificar a ocorrência de dor/desconforto osteomusculares relacionados ao trabalho em catadores que atuam em cooperativas de triagem na Região Metropolitana de São Paulo.

MÉTODO: Estudo transversal, com amostra constituída por 250 catadores distribuídos em quatro cooperativas, com entrevista dirigida por um instrumento de coleta de dados padronizado.

RESULTADOS: Entre os catadores predominou o gênero feminino (62\%), a idade entre 41-59 anos (53\%), a raça negra/parda $(66,4 \%)$ e abaixa escolaridade ( $77 \%$ com menos de oito anos de estudo). A dor/desconforto osteomuscular foi referida por 163 (65\%) dos catadores, entre esses, a localização na coluna foi a mais frequente (50\%), seguida dos membros superiores (45\%) e membros inferiores (31\%). Os resultados encontrados na análise multivariada mostraram que dor/desconforto estava associado aos meios de produção da cooperativa $(p<0.000)$, ao fato de ter tido outra ocupação ( $p=0.007)$ e ter tido acidente de trabalho $(p=0.043)$.

CONCLUSÕES: As condições de trabalho observadas eram extremamente precárias e constituíam importante fator de risco para distúrbios osteomusculares. Catadores estão expostos à mesma posição de trabalho por longo período, posturas inadequadas, monotonia, esforço físico, repetitividade e manuseio de materiais cortantes. As condições em que desempenham suas tarefas são prováveis fatores a problemas osteomusculares.

Descritores: catadores; reciclagem; fatores de risco; condições de trabalho; dor musculoesquelética; distúrbios musculoesqueléticos relacionados ao trabalho. 


\section{ABSTRACT}

Mandelli MCC. Work conditions and reported morbidity for musculoskeletal disorders in recyclable material collectors [Dissertação]. São Paulo: "Faculdade de Medicina, Universidade de São Paulo"; 2017.

INTRODUCTION: Urbanization has been accompanied by a growing increase in the volume and diversity of solid waste produced. The practice of reusing these wastes has been carried out since the beginning of the $X X$ century, initially by the figure of the "bottle dealer", up to 2003 when we had the recognition of the profession of "recyclable materials collector" in the Brazilian Classification of Occupations. The environmental problem caused by the production and disposal of waste led to the establishment of the National Solid Waste Policy, and among its guidelines there is an stimulus to the participation of the waste collector in the recycling chain.

Despite the improvements in the working conditions of the waste collector, exposures to biomechanical loads, such as physical stresses, vicious positions and repetitive movements persist. In addition, the organization of the production process and the way in which the collectors perform their tasks are situations that predispose to risks and damages to health.

OBJECTIVE: To identify the occurrence of musculoskeletal pain / discomfort related to the work of recyclable materials collector working in sorting cooperatives in the Metropolitan Region of São Paulo.

METHOD: A cross-sectional study with a sample of 250 collectors distributed in four cooperatives, with an interview conducted by a standardized data collection instrument.

RESULTS: Among the recyclable materials collector, the majority were women (62\%), with age between 41-59 years (53\%), of black / brown race (66.4\%) and low education ( $77 \%$ with less than 8 years of schooling). Musculoskeletal pain / discomfort was reported by $163(65 \%)$ of the recyclable materials collector, among them, the location in the spine was the most frequent (50\%), followed by upper limbs (45\%) and lower limbs (31\%). The results found in the multivariate analysis showed that pain/discomfort was associated with the means of production of the cooperative $(p<0.000)$, having had another occupation $(p=0.007)$ and having had a work accident previously $(p=0.043)$.

CONCLUSIONS: The working conditions observed are extremely precarious and constitute an important risk factor for musculoskeletal disorders. Waste pickers are exposed to the same work position for long periods, inadequate postures, monotony, physical effort, repetitiveness and handling of sharp materials. The conditions under which they perform their tasks are likely factors to musculoskeletal problems.

Descriptors: solid waste segregators; recycling; risk factors; work conditions; musculoskeletal pain; work-related musculoskeletal disorders. 
1. Introdução 



\section{Introdução}

\subsection{A reciclagem em seus aspectos socioambientais e a saúde dos catadores}

A reciclagem de resíduos sólidos vem se desenvolvendo nas últimas décadas como atividade econômica, propiciando geração de renda, principalmente a trabalhadores sem acesso ao mercado formal de trabalho; o que concomitantemente abriu novos mercados empresariais para a indústria transformadora, com grande apelo para a sustentabilidade socioambiental.

Um marco fundamental da reciclagem de resíduos sólidos no Brasil foi à elaboração da Política Nacional de Resíduos Sólidos (PNRS), consubstanciada na Lei $n^{\circ} 12.305$, tendo tramitado 20 anos nos espaços legislativos, até a sua promulgação no ano de 2010. Esta Lei rege a atuação da União, Estados e Municípios na gestão de resíduos sólidos, definindo suas respectivas competências e estabelecendo uma vigência de prazo indeterminado, com atualização a cada quatro anos (Brasil, 2010c).

A Lei foi regulamentada pelo Decreto $n^{0} 7.404 / 10$ e institui normas e procedimentos para implantação da PNRS, assim como princípios, objetivos, instrumentos, diretrizes, gestão integrada, obrigações dos geradores de resíduos sólidos e do Poder Público e as responsabilidades que devem caber à sociedade. 
Segundo a citada Lei, cada ente federado necessita apresentar um plano consistente de gestão de resíduos sólidos, dentro das competências político- territoriais que lhes cabem, para que haja repasse de recursos da União, aos Planos dos Estados, Distrito Federal e Municípios.

A Lei $n^{0} 12.305$ desencadeou a necessidade de que para o limite político-administrativo dos estados fosse criada uma Política Estadual de Resíduos Sólidos (PERS), objetivando uma gestão de resíduos sólidos (RS) mais eficiente, na qual o estado passa a ocupar o papel de apoiador e fomentador de recursos para a execução de ações destinadas ao manejo dos RS, que devem estar sob a responsabilidade dos municípios. Até 2012, quatorze dos vinte e seis Estados brasileiros e o Distrito Federal já tinham implantado suas respectivas PERS, contemplando especificidades locais (Campos, 2013). No Estado de São Paulo, a PERS foi instituída pelo decreto no $57.817 / 2012$.

Como obrigatoriedade legal, todo município deve apresentar seu Plano Municipal de Gestão Integrada de Resíduos Sólidos (PMGIRS), respeitando os princípios da PNRS. No momento presente, os municípios que declararam possuir um PMGIRS somam 2.325 ou 42\% dos municípios brasileiros, no que corresponde a uma população de 107 milhões de habitantes (52\%). Os municípios que ainda não têm PMGIRS somam 3.245 (58\%) e totalizam 97 milhões de habitantes, ou 48\% da população brasileira (Brasil. MMA, SINIR, 2016).

Atualmente, as principais metas definidas na PNRS são, entre outras: (1) extinção dos lixões a céu aberto até 2018; (2) redução de 70\% da massa de resíduos recicláveis ou reutilizáveis dispostos em aterros; (3) redução na 
geração de lixo de 1,1 Kg/hab./dia; e (4) inserção de 600 mil catadores (Brasil. MMA, SINIR, 2016).

Em relação aos catadores de materiais recicláveis, um dos aspectos relevantes da PNRS é o apoio à inclusão produtiva em organizações cooperadas. As cooperativas de catadores utilizam o descarte de RS, principalmente aqueles coletados nos centros urbanos. O Brasil possui hoje $85 \%$ de sua população vivendo em regiões urbanas (IBGE, 2013b). A oferta de infraestrutura urbana parece não acompanhar o crescimento populacional, pelo menos em proporção compatível à preservação adequada de condições mínimas da qualidade de vida, provocando problemas ambientais e sanitários de diversas ordens, um dos mais emergentes é o acúmulo desordenado e o desperdício de resíduos sólidos urbanos ${ }^{1}$ (RSU), o que coloca a gestão dos resíduos como tema pungente no cenário político contemporâneo.

Um detalhamento sobre o que tem sido denominado de RS aponta uma complexidade dos tipos de RS que variam conforme sua natureza, origem e composição. Os resíduos reaproveitáveis são denominados tecnicamente de resíduos sólidos secos (RSS), reconhecidos como todo material, substância, objeto ou bem descartado, que seja resultante de atividades humanas em sociedade e cuja destinação final é passível de recuperação em matéria-prima e disponibilização de um novo produto e os resíduos sólidos orgânicos constituídos por restos de animais e vegetais também são passíveis de aproveitamento(Brasil, 2010c).

\footnotetext{
${ }^{1}$ Materiais decorrentes das atividades humanas em sociedade, em domicílio, no comércio em empresas e em estabelecimentos públicos (Brasil, 2010c, art. $3^{\circ}, \mathrm{XVI}$ ).
} 
De acordo com Gouveia (2012), os resíduos sólidos advêm de diversos tipos de materiais, os quais geralmente são compostos de elementos sintéticos, sendo alguns, inclusive, perigosos aos ecossistemas e à saúde humana. Estes resíduos, quando descartados de maneira incorreta, podem ocasionar danos ao meio ambiente, prejuízos à saúde coletiva, onerar os órgãos públicos responsáveis pela limpeza urbana, aumentar o passivo ambiental da sociedade, e, ainda, provocar grande perda de oportunidade de obtenção de renda para os catadores e ganhos ao setor empresarial. O descarte adequado destes resíduos exige um concatenado sistema de produção e gestão, que compreende uma densa rede de coleta, destinação, armazenamento, reutilização e reciclagem, a serem executados de forma segura, eficiente e oportuna.

Uns dos objetivos da PNRS são diminuir o acúmulo dos RS, proteger a população e favorecer a sustentabilidade ambiental. Neste sentido foi instituída a obrigatoriedade da implantação de uma hierarquia para a gestão de resíduos sólidos urbanos (RSU), com as seguintes ações funcionais: (1) não geração; (2) redução; (3) reutilização; (4) reciclagem; (5) processamento e recuperação; e (6) disposição final de forma adequada (Brasil. MMA, ICLEI, 2012).

O município de São Paulo abriga 5,9\% da população do país, com um total de 11.252.473 habitantes, sendo a sexta cidade mais populosa do mundo (IBGE, 2013a) e responsável pela geração aproximada de 21 mil toneladas/dia de RSU, dos quais 10,5 mil toneladas correspondem aos resíduos de origem domiciliar (São Paulo (Cidade), [2016]). Plano de Gestão Integrada de Resíduos Sólidos da Cidade de São Paulo (PGIRS) publicado em 2014 estabelece as seguintes metas de governo: (1) ampliação da coleta seletiva de 
resíduos secos de 2\% para 10\%; (2) universalização da coleta seletiva, abrangendo todos os 96 distritos; (3) construção de quatro centrais de triagem mecanizadas; e (4) instalação de 84 novos Ecopontos (São Paulo (Cidade), [2016]).

A limpeza urbana da cidade é coordenada pela Autoridade Municipal de Limpeza Urbana (AMLURB), que possui a função de gerir a implantação da política governamental para o sistema de limpeza urbana. A coleta de resíduos domiciliares, de saúde e materiais recicláveis é realizada por duas empresas concessionárias: a Logística Ambiental de São Paulo S.A. (Loga), responsável pelos serviços na região Noroeste (Central, Norte e Oeste) e a EcoUrbis Ambiental S. A. (Ecourbis), responsável pela região Leste e Sul.

Atualmente, o Programa de Coleta Seletiva ${ }^{2}$ Solidária implantado no município de São Paulo apoiado em uma rede de 20 Centrais de Triagem semi mecanizada, possibilita a inclusão social de cerca de 1.100 catadores de material reciclável. Existem ainda, uma Central de Triagem de Resíduos de Equipamentos Eletroeletrônicos (REEE) credenciada e duas Centrais de Triagem Mecanizadas (São Paulo (Cidade), [2016]).

O reconhecimento do catador como profissional e sua inserção na coleta seletiva possibilita valorizar sua atividade produtiva, dada a utilidade pública de seu labor para a sociedade, uma vez que em seu trabalho participa da limpeza, preservação e recuperação do meio ambiente, ao mesmo tempo em que é favorecido por aprendizados sobre o sistema de reciclagem, especialmente quanto à diversidade dos produtos envolvidos.

\footnotetext{
${ }^{2}$ Coleta seletiva - recolhimento de resíduos sólidos separados na fonte geradora conforme sua constituição ou composição (Brasil, 2010c, art. 3º)
} 
As Cooperativas de Triagem (CT) estão organizadas de maneira autogestionária, prioritariamente constituídas por catadores que trabalham na recuperação de materiais recicláveis e na sua comercialização. As CT estão baseadas em práticas de economia solidária, nas quais a renumeração é realizada exclusivamente pela cooperativa e ocorre por sistema de rateio dos ganhos entre os cooperados (Gonçalves-Dias, 2009).

O trabalho convencional em uma cooperativa pode ser dividido entre as seguintes tarefas: coleta, triagem, transporte, prensagem, armazenamento e comercialização de materiais recicláveis. No trabalho realizado dentro de uma CT, o catador é impelido a armazenar o maior número possível de resíduos, para que a cooperativa atinja determinada competitividade de mercado ao ponto de tornar seus produtos comercializáveis em quantidade e qualidade, junto às indústrias de reciclagem, dada a oferta concorrente dos chamados grupos de sucateiros, atravessadores e similares.

Este processo produtivo, o pautado ganho em espécie (dinheiro), em função da produtividade do trabalho, pode provocar prejuízos à saúde do trabalhador, constituindo-se em fator de adoecimento.

O estado de saúde do trabalhador não é independente da sua atividade profissional. Guérin et al. (2006) destacam três aspectos importantes a serem observados no processo de trabalho para compreender os múltiplos fatores determinantes desta relação: (1) as condições de trabalho, que podem ser interpretadas quanto às condições físicas como ruído, temperatura e luminosidade;e condições organizativas do trabalho, o que inclui aspectos como turno, pausa, rodízio e produtividade; (2) os meios de trabalho para desenvolver a tarefa dizem respeito à disponibilidade de equipamentos, 
ferramentas e mobiliário e suas respectivas situações de funcionamento, manutenção e instalação; e, (3) a atividade de trabalho propriamente dita, que refere-se à percepção do trabalhador quanto a sua experiência na tarefa, tal que se pode classificá-la como penosa ou cansativa, dentre outras.

Os fatores de exposição a riscos presentes no processo de trabalho podem ser classificados de acordo com as suas características física, química, biológica, ergonômica e psicológica (Lavoie e Guertin, 2001).

As relações entre a saúde e atividade de trabalho ${ }^{3}$ podem ser estudadas cruzando-se informações sobre as condições nas quais atarefa ${ }^{4} e ́$ realizada em cada setor, a organização e condições físicas do local de trabalho e as características biológicas dos indivíduos (Guérin et al., 2006).

O estado de saúde de um trabalhador não é independente da sua atividade profissional. Porém, as relações entre o trabalho e a saúde são complexas, sendo múltiplos os fatores a estudar (Guérin et al., 2006).

Ramazzini, em 1700, na Itália,realizou uma descrição que se tornou clássica sobre doenças que costumavam ocorrer entre determinados ofícios, que foi consolidada na obra De morbis Artificum Diatriba (Fundacentro, 2004). Ramazzini dirigia aos seus pacientes a pergunta "Que arte tu exerces?", a partir da qual construía sua interpretação sobre as doenças que comumente aconteciam em uma profissão em particular.

\footnotetext{
${ }^{3}$ Atividade de trabalho é a mobilização das funções fisiológicas e psicológicas, o modo como o trabalhador realiza sua tarefa (Guérin et al., 2006). Deve ser observado in loco, por exemplo: na tarefa de triar, a catadora olha o RS à sua frente, faz os movimentos musculares para captar e depositar esse RS. Conjuntamente, desencadeia o processo cognitivo psicoprodutivo do andamento dessa ação.

${ }^{4}$ É o que o trabalhador deve realizar, é um objetivo a ser atingido (Guérin et al., 2006).

Por exemplo: no setor de triagem, a triadora tem como tarefa separar o RS.
} 
No Brasil, a produção de conhecimento na área da Saúde do Trabalhador se desenvolveu, principalmente a partir de 1988, com a sua inclusão na Constituição Federal, como resultado do movimento da Reforma Sanitária no Brasil (Rego et al., 2005).

É importante destacar que os catadores estão expostos a possíveis agentes contaminantes presentes nos resíduos durante a manipulação dos materiais recicláveis, além dos riscos gerais à sua integridade física no processo de trabalho (Ferreira e Anjos, 2001). A exposição a riscos relacionados a fatores biomecânicos presentes no ambiente de trabalho podem levar o catador a adquirir afecções musculoesqueléticas e originar queixas dolorosas crônicas.

Assim, transtornos funcionais mecânicos constituem um dos principais comprometimentos à saúde dos trabalhadores de reciclagem. Tais lesões acometem o sistema musculoesquelético e frequentemente resultam em estados dolorosos, fadiga, queda da produtividade e incapacidade temporária, passíveis de evoluírem para Distúrbios Osteomusculares Relacionados ao Trabalho (DORT) e outras síndromes dolorosas de caráter crônico (Couto et al., 2007).

Silva et al. (2007) revisaram a bibliografia publicada entre 1990-2006 sobre sintomas musculoesqueléticos relacionados à saúde do trabalhador, os respectivos instrumentos utilizados para a coleta de dados; demonstrando que em diversos países despontam as afecções crônico-degenerativas musculoesqueléticas, principalmente as lombalgias e algias dos membros superiores, entre os primeiros lugares no perfil de morbidade dos trabalhadores. 
Na perspectiva de agregar e sintetizar informações sobre a saúde do trabalhador e suas condições de trabalho, vem sendo propostos instrumentos que auxiliam a compreensão e fundamentação teórica das relações entre trabalhar e adoecer (Dejours, 1988).

Um instrumento de coleta de dados que pode atender à investigação dor/desconforto osteomuscular é o "Questionário Nórdico de Sintomas Osteomusculares" (QNSO) (Anexo I), que foi traduzido e validado no Brasil (Pinheiro et al., 2002), utilizando-se amostra de trabalhadores de uma Instituição Bancária Estatal em Brasîlia. A versão original chamada Nordic Musculoskeletal Questionnaire (NMQ) propõe padronizar a mensuração de relatos de sintomas osteomusculares (apud Pinheiro et al., 2002), o que facilita o levantamento de informações e comparações de diferentes pesquisas sobre doenças de origem ocupacional. Outro instrumento é o Questionário utilizado no levantamento de Sintomas Osteomusculares e Condições de Trabalho em Cabeleireiras (Mussi, 2005).

São raros os estudos relacionando as condições de trabalho de catadores de materiais recicláveis e a ocorrência de sintomas osteomusculares apenas em cooperativas. A literatura disponível aponta somente seis estudos com amostra de catadores de cooperativas entre os anos de 2007 e 2014, alguns desses estudos foram compostos por amostra mista de catadores cooperativados e autônomos. Destes, dois estudos (Maccarini e Hernández, 2007; Alencar et al., 2009) abrangem relatos da rotina de trabalho de catadores de cooperativas e autônomos, mas sem o propósito de estudar a relação entre condições de trabalho e sintomas osteomusculares. Porém, os sintomas musculares se destacaram entre os incômodos de saúde gerados no trabalho. 
Silva et al. (2007) tiveram como propósito específico o levantamento de dores no joelho entre catadores cooperados, catadores autônomos e garis; e identificaram relatos que associavam a ocorrência de sintomatologia osteomuscular às condições de trabalho. Os outros três estudos (Jesus et al., 2012; Bazo et al., 2011; Castilhos Junior et al., 2013) foram realizados com coletores de rua, catadores autônomos e cooperados, evidenciando-se sintomas osteomusculares, devido ao tipo de trabalho executado.

Pressupõe-se que a escassez de estudos sobre as condições de trabalho e sintomas osteomusculares em catadores de resíduos sólidos em cooperativa decorra de dois fatores: (1) a definição desse trabalho como atividade profissional ocorre apenas em 2002, quando incluída na Classificação Brasileira de Ocupações (CBO) pelo Código 5192 (Brasil. MTE, 2010, p. 807); (2) importância da reciclagem e de seus trabalhadores se destaca a partir da divulgação da PNRS somente em 2010, o que favoreceu a continuidade das cooperativas de materiais recicláveis por meio de apoio governamental e o estabelecimento da profissão de catador.

Este estudo teve como objetivos descrever as condições físicas e organizacionais do trabalho e a ocorrência de dor/desconforto osteomusculares em catadores de materiais recicláveis de cooperativas de triagem, utilizando a estratégia autorreferida para obtenção dos dados.

\subsection{Resíduos Sólidos}

O aumento observado na geração e descarte de resíduos sólidos tem sido acompanhado de uma ampla variação dos materiais nos quais são 
constituídos. Com a finalidade de mitigar as consequencias danosas do acúmulo de RS no meio ambiente, o conhecimento a respeito do tema tem avançado por meio de diversos estudos sobre sua classificação, geração, coleta e disposição final.

\subsubsection{Classificação dos resíduos sólidos}

A palavra lixo tem origem no latim lix, que significa cinza, associada às cinzas dos fogões a lenha (Mucelin e Bellini, 2008). A Associação Brasileira de Normas Técnicas (ABNT) define lixo como os "restos das atividades humanas, considerados pelos geradores como inúteis, indesejáveis ou descartáveis, podendo apresentar se no estado sólido, semi-sólido ou líquido, desde que não seja passível de tratamento convencional" (ABNT, 2004).

Por sua vez, resíduo sólido é o material, substância, objeto ou bem descartado resultante de atividades humanas em sociedade, cuja destinação final se propõe à utilização na recuperação tecnológica disponível (Brasil, 2010c, art.3ํ, XVI).

Pela Norma Brasileira de Resíduos (NBR) no 10.004, a ABNT (2004) define RS de diversas formas, podendo ser pela natureza física (secos ou molhados ${ }^{5}$ ), composição química (orgânico ou inorgânico ${ }^{6}$ ) e origem do resíduo (domiciliar, comercial, público, serviço de saúde e hospitalar, portos, aeroportos, terminais rodoviários e ferroviários, industrial, agrosilvopastoril e resíduos de construção civil) (Brasil, 2010c, capítulo I, art. 13).

\footnotetext{
${ }^{5}$ Os resíduos secos são constituídos por embalagens plásticas, vidros, papéis, metais diversos e longa vida; os resíduos molhados são constituídos por restos de alimento, como folha, casca, sementes e resto de produtos industrializados (ABNT, 2010; Brasil, 2010c, capítulo I, art. 9²) ${ }^{6}$ Os resíduos orgânicos são resíduos úmidos que se decompõem em pouco tempo, enquanto que os inorgânicos são resíduos secos que demoram muitos anos para se decompor (Brasil, 2010c, capítulo I, art.9; Brasil. MMA, ICLEI, 2012)
} 
Cada tipo de RSS tem sua separação e armazenamento diferenciado em uma cooperativa de triagem. Por sua vez, podemos encontrar diversos subtipos de um mesmo tipo de material reciclável, para o quais existe mercado específico para a comercialização com vista a suprir a demanda da indústria de transformação. Os RSS que são separados por subtipos são os papéis, plásticos, metais, alumínio, vidros, isopor e produtos eletrônicos e seus componentes. A maior quantidade de resíduos sólidos encontrados e armazenados nas cooperativas são os plásticos e os papéis (Abrelpe, 2013).

A parte contaminada dos resíduos sólidos é denominada de rejeito, que são aqueles resíduos que não podem ser aproveitados, por não terem sido separados corretamente ou de alguma forma terem sofrido deterioração, ou ainda, podem ser constituídos de resíduos provenientes de atividade de higiene pessoal, ou aqueles resíduos que não são passíveis de tratamento e recuperação, mediante as técnicas disponíveis atualmente (Brasil, 2010c, capítulo II, art.3).

Porém, parte dos rejeitos é muitas vezes RSS que poderiam ser reaproveitáveis, quando visto como um objeto útil, seja na reutilização ou reciclagem.

\subsubsection{Geração dos Resíduos Sólidos}

A geração dos resíduos sólidos é influenciada principalmente pelo desenvolvimento econômico, nível de industrialização, perfil de produção e hábitos de consumo. É reconhecido que, quanto maior o desenvolvimento econômico e o nível de urbanização, maior tem sido a quantidade de RSU gerada; sendo que, o padrão de renda e a urbanização estão altamente 
correlacionados. Países com alta renda per capita produzem mais RS comparados aos de menor renda. A composição dos resíduos também é influenciada pelas mesmas condições que geram os RS. Em países de maior renda, a composição dos RS constitui-se em papéis (31\%), orgânicos (28\%), outros (17\%), plásticos (11\%), vidros (7\%) e metais (6\%). Nos países de menor renda, a proporção de resíduos orgânicos é maior em relação a dos países de maior renda (Hoornweg e Bhada-Tata, 2012a).

Em 2012, o Banco Mundial elaborou o relatório What a Waste: A Global Review of Solid Waste Management. Nele, informou que atualmente a geração de RSU globais é de cerca de 1,3 bilhões de toneladas/ano. Neste caso, cada habitante do planeta geraria em torno de $1,2 \mathrm{Kg} / \mathrm{dia}$, sendo estimado um aumento de cerca de 2,2 milhões de toneladas/ano até 2025 e geração de 1,42 $\mathrm{Kg}$ de RSU por pessoa/dia. Isso representa um aumento significativo das taxas de geração de resíduos percapita nos próximos quinze anos. No entanto, as médias globais são amplas, variando consideravelmente por região,país, e até mesmo entre cidades(Hoornweg e Bhada-Tata, 2012b).

No Brasil, pesquisa realizada em alguns municípios pela Associação Brasileira de Empresas de Limpeza Pública e Resíduos Especiais (Abrelpe) no ano de 2014 a geração total de RSU foi de aproximadamente 78.6 milhões de toneladas/ano (Abrelpe, 2014).

Em relação ao índice per capita de coleta de RSU, o Brasil apresentou uma média de 0,963 Kg/hab/dia. A Região que mostrou um índice maior foi a Sudeste, com 1,205 Kg/hab/dia, sendo o menor na Região Norte, com 0,722 Kg/hab/dia (Abrelpe, 2014). O Estado de São Paulo apresentou 1,346 $\mathrm{Kg} / \mathrm{hab} / \mathrm{dia}$ e a cidade de São Paulo 1,221 Kg/hab/dia, mas há variação dos 
resíduos gerados nas subprefeituras, na Cidade Tiradentes é respectivamente 0,63Kg/hab/dia e 1,73 Kg/hab/dia em Pinheiros (São Paulo (Cidade), [2016]).Estima-se que o Município de São Paulo gere em torno de 1,4 kg/dia de resíduos domiciliares por pessoa (IPEA, 2012; São Paulo (Cidade), [2016]).

Embora a geração de RS esteja diretamente relacionada ao tamanho populacional, uma adequada política e gestão de RS, tal como a implantação da coleta seletiva com alta cobertura de serviço, pode diminuir a quantidade de rejeito. Outro dado importante é que a quantidade de cooperativas de triagem e de catadores influencia diretamente no volume coletado.

Nota-se que os catadores possuem um excesso de trabalho, tendo em vista os volumes de RSU gerados na Região Metropolitana de São Paulo (RMSP) e o fato de que o Programa de Coleta Seletiva é realizado por apenas 20 Cooperativas de Triagem. No total, estas cooperativas contam com aproximadamente 1.100 catadores no trabalho de beneficiamento dos RS (São Paulo (Cidade), [2016]),ou seja, há uma média de 50 catadores por cooperativa.

\subsubsection{Coleta seletiva de resíduos sólidos}

A Coleta seletiva é um sistema de recolhimento diferenciado de resíduos pré-selecionados na fonte geradora, em domicîios, indústrias, estabelecimentos comerciais, escolas etc. Pressupõe que ocorra a separação dos resíduos recicláveis nessas fontes produtoras tais como papéis, vidros, plásticos, metais ou, até mesmo, resíduos orgânicos (Brasil, 2010c, capítulo II, art. $3^{\circ}$ ). Ocorre porta a porta, em pontos de entrega voluntária (PEV) e em 
operações programadas, conhecidas como "Operação cata bagulho". Neste caso, são resíduos acondicionados em volumes grandes, e geralmente a coleta ocorre nos finais de semana (Brasil. MMA, ICLEI, 2012).

As cooperativas de triagem também retiram os resíduos em locais específicos, quando ocorre o pedido de retirada por parte do cidadão. Esse tipo de coleta ocorre geralmente quando se dispõe de maior quantidade de materiais que o rotineiro, sendo em situações de mudança de moradia, falecimento e separação conjugal.

A quantidade de Cooperativas e Associações de triagem na região metropolitana de São Paulo encontra-se em torno de 49 (Besen et al., 2014).

Na cidade de São Paulo, o roteiro da coleta seletiva é planejado pela Amlurb e empresas concessionárias. Os veículos utilizados na coleta seletiva dos RSU são do tipo caminhões compactadores ou com caminhões com carrocerias do tipo gaiolas (São Paulo (Cidade), [2016]).

No ano de 2011 a coleta da RMSP correspondia cerca de 10\% do coletado no país, e o município de São Paulo foi responsável pela geração de mais de $62,5 \%$ desses resíduos (Jacobi e Besen, 2011). Estima-se que, no ano de 2013 , tenham sido coletadas mais de 21.000 toneladas diárias de resíduos sólidos urbanos na RMSP, dos quais 60,9\% somente no município de São Paulo (Cetesb, 2013).

O sistema de coleta seletiva é estruturado em itinerários regulares dentro de uma região, bairros e ruas, com frequência semanal e horários específicos. Diversas estratégias são propostas com a finalidade de avaliar a produtividade da coleta. Uma delas, e a mais comum, é o cálculo da quantidade de resíduos coletado e a quantidade de resíduos comercializados a 
partir deste montante a diferença entre tais quantitativos corresponde a rejeitos, que posteriormente são destinados aos aterros.

No Brasil, conforme amostragem de alguns municípios que tiveram interesse em ser estudado, o índice de abrangência da coleta de RSU é de aproximadamente $90,68 \%$, no Sudeste abrange aproximadamente $97,29 \%$, no Sul $94,26 \%$, no Centro-Oeste $93,38 \%$, no Norte, $80,83 \%$, e no Nordeste, 78,53\% (Abrelpe, 2014).

Porém, outro levantamento que diz respeito à coleta seletiva apresentou outra situação dos municípios brasileiros, os que possuem coleta seletiva são $1.320(23,7 \%)$, os que não possuem são $2.445(43,9 \%)$ e os municípios sem informações declaradas a respeito do serviço de coleta seletiva foram 1.805 (32,4\%). Dos resíduos coletados nesses municípios apenas 2\% são destinados para a reciclagem (Brasil. MMA, SINIR, 2016).

Provavelmente isso se deve à implantação do PGIRS, a quantidade de pontos de entrega voluntária, associações/cooperativas de catadores e catadores autônomos.

Considera-se que o envolvimento da população seja condição necessária para a obtenção de maior quantidade de resíduos reaproveitados. Porém, mudanças de hábitos demoram a ser incorporadas no dia a dia.

Todos os tipos de coleta, quando realizados de forma adequada na fonte geradora, ou seja, quando a separação e a disposição dos resíduos para a coleta seletiva contribuem para aumentar a quantidade e qualidade desses resíduos, refletem no aumento do seu valor comercial, favorecendo as cooperativas de triagem, maior aproveitamento de RS para indústrias 
transformadoras, e favorecimento da preservação do meio ambiente, ao extrair menor quantidade de matéria-prima.

\subsubsection{Disposição dos resíduos sólidos}

A PNRS considera a disposição final ambientalmente adequado dos rejeitos em aterros sanitários, pelo fato do solo ser impermeabilizado, evitando o escoamento do chorume na superfície de modo a resguardar danos ou riscos à saúde e à segurança pública e minimizar os impactos desfavoráveis ao meio ambiente. Os aterros controlados são considerados uma maneira de disposição final imprópria, o solo não é impermeabilizado; o depósito dos resíduos é feito no solo recoberto por uma camada de material inerte; não há controle dos subprodutos da decomposição, tais como chorume e gases; não contam com sistema de tratamento ou recirculação, e o lixão, onde ocorre à descarga dos resíduos diretamente no solo e a céu aberto sem qualquer tipo de controle ambiental ou técnica apropriada, também possui um ciclo de poluição ascendente e descendente (ABNT, 1985, 1992; Brasil, 2010c, capítulo II, art. $3^{\circ}$ ). Desde 2014, a PNRS permite aterrar apenas os rejeitos dos diversos tipos de tratamento, ou seja, os resíduos que não podem ser reaproveitados e reciclados (Brasil, 2010c).

No Brasil, das 78,6 milhões de toneladas de resíduos sólidos geradas em 2014, uma quantidade significativa de 29,6 milhões de toneladas foi disposta em lixões e aterros controlados. Esses dados apontam que mais de 78 milhões de brasileiros - o equivalente a 38,5\% da população total do País não têm acesso a serviços de tratamento e destinação adequada de resíduos. 
Esses dados referem-se à amostragem dos municípios estudados pela Abrelpe e os respectivos gerenciamentos dos RS quanto à coleta e as disposições finais (Abrelpe, 2014).

Ainda neste mesmo contexto do cenário brasileiro, os municípios do Brasil que dispõem os resíduos sólidos em aterros sanitários são 2.215 municípios (40\%), estes municípios representam 129 (63\%) milhões de habitantes e os municípios que dispõem seus resíduos sólidos em aterros controlados ou lixões é de 3.355 (60\%), representa 74,7 milhões de habitantes (37\%) (Brasil. MMA, SINIR, 2016).

Nos países de renda média alta, as destinações finais dos RS mostraram disposição em aterros (59\%), lixões (33\%), outros (6\%), compostagem (1\%) e reciclagem (1\%) (Hoornweg e Bhada-Tata, 2012a).

O prazo final estabelecido pela PNRS para o fechamento dos lixões nas capitais e nos municípios da Região Metropolitana foi estendido para ano de 2018. Mantêm-se os propósitos de redução do volume de resíduos gerados, de ampliação da reciclagem, de coleta seletiva com inclusão de catadores, de destinação final adequada para os rejeitos, com implantação de aterros sanitários onde apenas serão recebidos dejetos de última instância, por não poderem ser aproveitados (Brasil. Senado Federal, 2015).

É importante destacar que significativa quantidade dos RSU produzidos atualmente no Brasil não possuem destinação sanitária adequada. 


\subsection{Cooperativas de Materiais Recicláveis}

A organização dos catadores em associações e cooperativas no Brasil é recente. A primeira formação foi a Associação de Carroceiros no município de Canoas em 1985 (Bosi, 2008), em São Paulo a primeira organização conhecida foi em 1986 e institui-se como cooperativa em 1989, Cooperativa de Catadores Autônomos de Papel, Aparas e Materiais recicláveis - COOPAMARE -(Ribeiro e Besen, 2007). Essa organização de catadores em cooperativas e associações tem demonstrado um alto potencial inclusivo e vem sendo estimulada pela adoção de políticas públicas de geração de renda, que ao mesmo tempo têm contribuído para a conscientização e valorização dos trabalhadores envolvidos (Grimberg, 2007). Para compreensão dessa organização este tópico apresenta a sistematização e a composição da sua estrutura física e seus componentes.

\subsubsection{Aspectos da Organização}

Uma cooperativa de trabalho é uma sociedade constituída por trabalhadores para o exercício de suas atividades profissionais, com aproveitamento comum dos meios de produção, autonomia e autogestão, visa obter melhor qualificação, renda, situação socioeconômica e condições gerais de trabalho (Brasil, 2012, art. $2^{\circ}$ ).

De acordo com a legislação brasileira, as cooperativas são classificadas conforme "o objeto ou pela natureza das atividades desenvolvidas por elas ou por seus associados" (Brasil, 1971, art. 10). As cooperativas de catadores de 
materiais recicláveis são classificadas como associações de produção, sendo constituídas por sócios que contribuem com o trabalho para a produção em comum de bens (Brasil, 2012).

Os princípios que regem as cooperativas são: adesão livre e voluntária; gestão democrática; participação econômica dos membros; autonomia e independência; educação, formação e informação; intercooperação; interesse pela comunidade; preservação dos direitos sociais e do valor social do trabalho; não precarização do trabalho; respeito às decisões de assembleia; participação na gestão em todos os níveis de decisão, de acordo com o previsto pela lei e pelo seu estatuto social (Brasil, 2012).

Do ponto de vista econômico, os cooperados têm como direito retiradas não inferiores ao piso da categoria profissional e, na ausência deste, não inferiores ao salário mínimo; duração do trabalho normal não superior a 8 (oito) horas diárias e 44 (quarenta e quatro) horas semanais; repouso semanal remunerado, preferencialmente aos domingos; repouso anual remunerado; retirada para o trabalho noturno superior à do diurno; adicional sobre a retirada para atividades insalubres ou perigosas; seguro contra acidente de trabalho(Brasil, 2012). Porém, as cooperativas de triagem ainda não conseguem dispor por completo da maior parte dessas condições.

São realizadas assembleias gerais, ordinárias e extraordinárias para cada tipo de assunto pertinente ao trabalho realizado. Uma vez ao ano ocorre uma assembleia geral especial para tratar da gestão, aspectos disciplinares, direitos e deveres dos sócios, organização do trabalho, regras, planejamento de projetos e resultados econômicos (Brasil, 2012). A coordenação das atividades desenvolvidas por cada cooperado é definida nas assembleias 
gerais e no próprio contrato associativo. Qualquer sugestão, reclamação ou exigência que o cooperado, o líder ou o presidente tenha a fazer, sempre será feita por meio da coordenação. A eleição para coordenador é feita em assembleia (OCB, 2012).

O número de Cooperativas de Triagem no Brasil é uma informação que vem sendo coletada pelo Movimento Nacional dos Catadores de Materiais Recicláveis (MNCR) e pelo Ministério do Meio Ambiente (MMA). De acordo com a fonte desta informação, os dados divergem com relação à quantidade de cooperativas; isto em parte poderia ser melhorado, se o sistema fosse atualizado periodicamente e a alimentação dos dados partisse de um cadastro único informatizado das cooperativas de triagem. O Ministério do Meio Ambiente divulga que existem ao menos 1.175 organizações coletivas de catadores em funcionamento em todo o país, distribuídas em 684 municípios (Brasil. MMA, [2012]) e cerca de 60\% das organizações coletivas de catadores encontram-se em níveis mais baixo de eficiência (Ministério do Desenvolvimento Social e Combate à Fome. MNCR, 2006, PNRS, 2012).

As cooperativas de reciclagem têm uma função social fundamental para os catadores ao inseri-los no mercado de trabalho, criando uma rotina diária de responsabilidades, favorecendo a convivência entre eles e também inclusão social, elevando-os à categoria de pessoas com condições de adquirir bens. Para o meio ambiente, as cooperativas colaboram com a limpeza, sustentabilidade e preservação de recursos naturais. 


\subsubsection{Galpão, Cooperativa ou Central de Triagem - Estrutura Física e Seus Componentes}

No Brasil, as denominações mais comuns de organizações de catadores de materiais recicláveis são: Galpão, Associação, Cooperativa ou Central de Triagem (Campos, 2013). A localização das organizações de catadores é valorizada de acordo com sua proximidade de acesso ao transporte público e para a retirada dos materiais que serão comercializados, cujo encargo é das empresas transformadoras.

O tamanho dos galpões costuma variar de acordo com as necessidades do fluxo de recebimento, triagem, processamento, estocagem dos materiais recicláveis e área física destinadas à administrativa, treinamento, reuniões, cozinha, vestiários, banheiros e estacionamento (Lajolo, 2003a). Segundo o Plano de Aceleração de Crescimento (PAC), o tamanho do galpão de triagem

pode ser classificado em: pequeno $\left(300 \mathrm{~m}^{2}\right)$, médio $\left(600 \mathrm{~m}^{2}\right)$ e grande $(1.200$ $\mathrm{m}^{2}$ ) (Brasil. MMA, Ministério das Cidades, 2008).

Dentro da infraestrutura do galpão, a pavimentação e o sistema de drenagem de águas, o tratamento de esgoto e o fornecimento de água constituem itens indispensáveis a serem verificados, além do fornecimento de energia e a distribuição elétrica, que devem se adequar às especificações técnicas dos equipamentos e dos sistemas de ventilação e iluminação (Lajolo, 2003b).

A organização do espaço físico nas cooperativas deve ocorrer de modo a facilitar a chegada dos materiais, o despejo do volume coletado no silo, a 
triagem na mesa/esteira dos subtipos de resíduos, o deslocamento desses materiais recicláveis (MR) para as baias da balança e da prensa; locais de fácil acesso para colocação e retirada das caçambas de metais e vidros; estocagem e retirada de fardos conforme a venda, e a disposição dos big-bags de rejeitos, de modo geral ficam em local externo ao galpão (Lajolo, 2003; Brasil. MMA, Ministério das Cidades, 2008).

Os equipamentos mínimos necessários para a realização do trabalho são: a prensa, a balança, a esteira/mesa de triagem, a empilhadeira, o carrinho plataforma, os contêineres plásticos e metálicos, e as big-bags (Lajolo, 2003).

A prensa é um equipamento primordial nas cooperativas, tem a finalidade de compactar os MR, deixando em formato de fardo, facilitando o transporte desses materiais prensados e diminuindo a ocupação do espaço físico. A balança é um equipamento utilizado para aferir o fluxo de entrada e saída dos MR, podendo também ser utilizada para medir a produção dos cooperados e fazer estimativa gravimétrica dos MR e dos rejeitos de uma cooperativa. A esteira é um equipamento mecanizado e a mesa é um objeto não mecanizado, onde são dispostos os subtipos de MR para o processo de triagem.

A empilhadeira é um transporte mecanizado utilizado para o deslocamento interno de fardos, facilitando o armazenamento vertical. O carrinho plataforma é um transporte manual utilizado para deslocamento interno de big-bags e alguns fardos de MR.

Também são necessárias as sacolas de ráfia (big-bags), objeto utilizado para armazenamento. São sacos com capacidade volumétrica de $3 \mathrm{~m}^{3}$, resistentes a $40 \mathrm{~kg}$. Estes sacos são utilizados na coleta, na triagem e na 
movimentação internados MR, sendo utilizados principalmente para resíduos de papéis e plásticos. Os contêineres plásticos ou de papelão possuem em média capacidade para 120 litros. Têm o mesmo uso dos big-bags, só que os materiais recicláveis armazenados neles são os metais, vidros e demais materiais perfuro cortantes. Outros tipos de recipiente destinado ao acondicionamento, como caçamba metálica, geralmente são disponibilizadas pelas empresas que compram os materiais recicláveis.

\subsection{Descrição dos Catadores de Materiais Recicláveis}

Os catadores integram o panorama brasileiro urbano há muitos anos (IPEA, 2013) e vem aumentando a sua participação numérica, principalmente a partir da década de 1980 (Bosi, 2008); entretanto, ainda não é possível obterse um número exato desses profissionais atuantes, dadas as características próprias do trabalho, com informalidade e alta rotatividade (IPEA, 2013) e um dinamismo acentuado na estruturação do processo de trabalho.

\subsubsection{O reconhecimento do catador como profissão}

O catador tem marcado presença na gama de profissões urbanas pelo menos desde $\mathrm{o}$ início do século $\mathrm{XX}$, embora o imaginário coletivo costumeiramente tenha retratado o catador por meio da figura do "velho garrafeiro" (Pinhel, 2013), percorria trechos da cidade em busca de jornais e garrafas, que eram os materiais comercializados na época; a oficialização da profissão de catador de materiais recicláveis é recente. 
Em meados de 1999, ocorreu no Brasil a formação do Movimento Nacional dos Catadores de Materiais Recicláveis (MNCR), durante o I Encontro Nacional de Catadores de Papel em Brasilia. O evento reuniu cerca de 1.700 catadores. Os representantes do MNCR atuaram com a finalidade de ser reconhecidos por políticas públicas de inclusão profissional e pelo incentivo à organização em cooperativas/associações, nas quais todos são responsáveis pelo seu processo de produção, tendo decisão de todos para a execução dos planejamentos e mudanças.

A profissão de catador de materiais recicláveis foi formalizada na Classificação Brasileira de Ocupações (CBO) em 2001, de acordo com o Ministério do Trabalho e Emprego, sob o código $n^{0}$ 5192-05 MTE/SENAES, 2003. O acesso ao trabalho é livre, sem exigência de escolaridade ou formação profissional. Tem como recursos de trabalho ferramentas manuais, carrinho de mão, esteira/mesa de triagem, balança, prensa, empilhadeira, utilização de uniformes e equipamentos de proteção individual (Brasil. MTE, 2010).

Em 2011, ocorreu a subdivisão da atividade profissional e suas funções pelo Ministério do Trabalho e Emprego (MTE) (Quadro 01), sendo elaborada pelos próprios catadores.

Quadro 01. Classificação Ocupacional e Funções dos Catadores de Materiais Recicláveis

\begin{tabular}{|c|l|}
\hline TíTULOS & \multicolumn{1}{|c|}{ FUNÇÃO } \\
\hline $\begin{array}{c}5192-05 \text { - Catador de material } \\
\text { reciclável }\end{array}$ & $\begin{array}{l}\text { Catador de ferro-velho, Catador de papel e papelão, } \\
\text { Catador de sucata, Catador de vasilhame, Enfardador } \\
\text { de sucata (cooperativa) }\end{array}$ \\
\hline $\begin{array}{c}5192-10 \text { - Selecionador de } \\
\text { material reciclável }\end{array}$ & $\begin{array}{l}\text { Separador de material reciclável, Separador de } \\
\text { sucata, Triador de material reciclável, Triador de } \\
\text { sucata }\end{array}$ \\
\hline $\begin{array}{c}5192-15 \text { - Operador de prensa } \\
\text { de material } \\
\text { reciclável }\end{array}$ & $\begin{array}{l}\text { Enfardador de material de sucata (cooperativa), } \\
\text { Prenseiro, Prensista }\end{array}$ \\
\hline
\end{tabular}

FONTE: Brasil, MTE, CBO, 2011. 
Pela PNRS (Brasil, 2010c), as associações e cooperativas foram definidas como agentes prioritários para a realização da coleta seletiva no Brasil. Antes disso, em 2003, o Governo Federal criou o Comitê Interministerial de Inclusão Social dos Catadores, viabilizando políticas que considerassem liberação de recursos financeiros para estudos, pesquisas, capacitação e formação profissional; compra de veículos coletores e equipamentos para pesagem, prensagem e construção de edificações. O Decreto nº 5940/06 em repartições públicas federais elegeu os catadores como beneficiários dos materiais da coleta seletiva, passando a ser obrigatório aos estados e municípios brasileiros que todos os materiais provenientes das coletas seletivas fossem destinados aos catadores, como forma de tirarem seus ganhos (Brasil, 2003, 2006, 2010c).

Como outras formas de apoio à profissão existem investimentos do Governo Federal realizados em benefícios da formação profissional e condições de trabalho, como Secretaria Nacional de Economia Solidária (SENAES) - Ministério do Trabalho e Emprego (MTE) - Fortalecimento do Associativismo e Cooperativismo dos Catadores de Materiais Recicláveis (CATAFORTE) -Fundação Nacional de Saúde(FUNASA) - Petróleo Brasileiro SIA (PETROBRAS)-Banco Nacional de Desenvolvimento Econômico e Social (BNDES) e o Banco do Brasil, com o objetivo de promover a organização de catadores autônomos, oferecerem assessoria, incubação, capacitação, equipamentos, galpões, caminhões e outros veículos, planos de negócios sustentáveis em redes solidárias e linhas de créditos (Brasil, 2010b).

Desde 2003, os catadores da cidade de São Paulo são contemplados por programas que visam integrar e articular as ações do Governo Federal 
voltadas ao apoio e ao incentivo à organização produtiva dos catadores de materiais recicláveis e reutilizáveis. O Decreto Municipal 42.290/2002 que instituiu o "Programa Socioambiental Cooperativas de Catadores de Materiais Recicláveis" foi revogado pelo Decreto Municipal 48.799/2007 que the conferiu nova normatização com o "Programa Socioambiental de Coleta Seletiva de Resíduos Recicláveis" (São Paulo (Cidade), 2002, 2007). No âmbito federal o decreto n. 7.405/2010 visa melhorar as condições de trabalho; ampliar as oportunidades de inclusão social e econômica; e, expandir a coleta seletiva de resíduos sólidos, reutilizando e reciclando por meio deste segmento (Brasil, 2010b).

Este programa possibilitou a instalação de centrais de triagem, as chamadas cooperativas de catadores, em áreas públicas municipais e/ou galpões designados pela municipalidade, com responsabilidade operacional e administrativa a cargo dessas cooperativas conveniadas com a Prefeitura (São Paulo (Cidade), 2014).

Em 2013, o censo realizado pelo IBGE registrou o número de 387.910 pessoas autodeclaradas catadoras (IPEA, 2013). Não é possível estabelecer objetivamente o número absoluto de catadores e sua distribuição nas regiões geográficas brasileiras, pois muitos trabalham na informalidade, com rotatividade elevada, e muitas cooperativas estão em processo de formalização.

Gonçalves-Dias (2009) enfatiza o papel dos catadores de materiais recicláveis como profissionais fundamentais para a cadeia produtiva e para a indústria de reciclagem. Os catadores aparecem como um elo frágil do campo do trabalho, vive em um processo de exclusão/inclusão social em situação 
caracterizada por zonas de vulnerabilidade, fragilidade e precariedade. São submetidos a precárias condições de trabalho e baixa renumeração. A autora também observa que esses trabalhadores sofrem um segundo tipo de exclusão pelas indústrias transformadoras ao necessitar demonstrar eficiência na qualidade e quantidade de MR, e ao aceitar preços impostos por elas para que tenham sua atividade profissional garantida. Além disso, dependem da coleta seletiva por meio da colaboração da população na separação correta, e da infraestrutura disponível à cooperativa para cumprir com a demanda dessas indústrias.

Em estudo sobre a estruturação das indústrias de reciclagem, Burgos (2009) observou que os catadores de materiais recicláveis realizam suas atividades na base da indústria da reciclagem sem, no entanto, tornarem-se propriamente empregados da indústria. São consumidos produtivamente em sua força de trabalho por participarem do processo de recuperação da mercadoria e contribuir para o aumento do lucro da indústria de reciclagem por meio da produção de matéria-prima barata. Isso leva ao desgaste de suas condições físicas, psíquicas e emocionais, pelas condições precárias de trabalho e pela exploração dos agentes do mercado de transformação.

\subsection{Justificativa}

A questão dos resíduos sólidos, as desigualdades sociais e a preservação do meio ambiente são alguns dos problemas mundiais mais alarmantes, as complexidades destas demandas envolvem buscar soluções 
para a recuperação do descarte dos resíduos sólidos e propiciar a geração de renda.

A cultura de consumismo apregoada nas últimas décadas tem como um dos princípios o conceito de obsolescência programada, que pré-determina tecnologicamente o tempo de vida útil das mercadorias, induzindo os consumidores à crença de que seus objetos se encontram ultrapassados e necessitam ser descartados (Conceição et al., 2014).

Paralelamente, tem ocorrido um aumento da produção de bens de consumo acompanhada de um crescimento da produção de embalagens, atendendo à praticidade da vida moderna, mas gerando grande quantidade de descartáveis tais como vidros, papéis, metais e plásticos (Fabris et al., 2006). A recuperação destes descartáveis ocorre por meio da coleta seletiva, onde a organização de catadores de materiais recicláveis mostra-se como um aspecto relevante neste processo produtivo.

Uma vez implantada a coleta seletiva, o volume gerado de recicláveis que podem ser destinados à comercialização, depende da quantidade de resíduos sólidos em condições de aproveitamento, assim como da quantidade de catadores e de equipamentos disponível na cooperativa, das condições de trabalho e da eficiência na execução de cada tarefa.

O desenvolvimento das cooperativas de triagem constituídas por catadores tem sido estimulado mediante a instituição de leis ordenadoras do descarte e reciclagem de resíduos; o que tem propiciado uma perspectiva promissora de trabalho e sustento para inúmeras famílias. Atualmente, o processo de reciclagem é a melhor forma de destinação dos resíduos após o consumo, sendo o principal meio de recuperação de materiais, de prolongar a 
vida útil dos aterros sanitários e contribuir para tornar sustentável a exploração de matérias-primas naturais.

Os catadores geralmente encontram-se expostos a precárias condições de trabalho, desde a mais visível, tal como espaços de trabalho penosos e perigosos, até condições não percebidas ou ignoradas. Quanto ao seu convívio com os demais catadores, também podem enfrentar violência verbal e a intolerância de diversas ordens, quase invariavelmente levando a situações conflitantes, até algumas vezes inconciliáveis, afetando a sua saúde emocional em longo prazo.

Destaca-se que os catadores estão expostos a possíveis agentes biológicos e químicos presentes nos resíduos e no ambiente de trabalho; aos agentes físicos e mecânicos, envolvidos nas condições e organização do trabalho (Ferreira e Anjos, 2001). Os riscos biomecânicos constituem um dos principais comprometimentos aos catadores, devido seu trabalho ser executados quase que prioritariamente de modo manual, podendo predispor a lesões musculoesqueléticas que frequentemente resultam em estados dolorosos, evoluindo a fadiga e incapacidade temporária (Couto et al., 2007).

A observação das condições físicas (ruído, luminosidade e temperatura) e das condições de organização constitui uma maneira que visa compreender como se estruturam os riscos de exposição no ambiente laboral, tornando possível propor medidas eficazes para prevenir agravos relacionados ao trabalho.

Existem poucas pesquisas pontuando a associação entre o perfil de saúde do catador e as condições de trabalho nas cooperativas de triagem. Os estudos encontrados são na sua maioria do tipo descritivo, enfatizando a 
quantidade de resíduos sólidos coletados e comercializados, frente a características sociodemográficas (Velloso et al., 1997).

A escassez de estudos sobre as condições de trabalho e sintomas osteomusculares referidos por catadores de materiais recicláveis, dificulta a comparação dos resultados com os achados de outros pesquisadores e valoriza investigações sobre o tema.

A Região Metropolitana de São Paulo é a mais populosa do país, havendo a circulação de um número expressivo de pessoas e um imenso volume gerado diariamente de resíduos sólidos, bastante diversificados, o que torna este recorte, um território estimulante para aplicação desta pesquisa. 

2. Revisão Bibliográfica 



\section{Revisão Bibiográfica}

O descarte e a recuperação representam ações importantes a serem contempladas por qualquer política pública de RS. APNRS apoia a participação do catador na implementação da Responsabilidade Compartilhada e da Logística Reversa, favorecendo sua inclusão socioeconômica, ao reconhecê-lo como agente ativo na instituição desta políica. A segurança e a saúde dos catadores são desafios a serem enfrentados na gestão das cooperativas e um passo importante nesta direção pode ser dado mediante iniciativas que compatibilizem as condições do ambiente de trabalho às normas regulamentadoras. São esses aspectos que serão tratados na presente revisão.

\subsection{Diretrizes da Política Nacional em favor do catador}

A resolução ou minimização do descarte de RS vem sendo frequentemente discutida por órgãos públicos, organizações de catadores, instituições privadas, organizações sociais e indústrias de transformação.

Umas das diretrizes mais importantes da PNRS é a responsabilidade compartilhada $^{7}$, abrangendo os geradores, importadores, fabricantes, distribuidores, comerciantes, o Estado e o cidadão. Por meio dela é

\footnotetext{
${ }^{7}$ Responsabilidade compartilhada pelo ciclo de vida dos produtos como conjunto de atribuições envolvendo os fabricantes, importadores, distribuidores, comerciantes, consumidores, serviço público de limpeza urbana e manejo dos resíduos sólidos pela minimização do volume de resíduos sólidos e rejeito gerados (Brasil, 2010c).
} 
considerado o ciclo de vida do produto, buscando minimizar o impacto dos resíduos sólidos no ambiente e na saúde humana (Brasil, 2010c).

Outra importante diretriz instituída pela PNRS é o conceito de Logística Reversa $^{8}$, segundo a qual se estabelece um acordo com o setor empresarial com o propósito de incentivar a reutilização e reciclagem, gerando novos produtos, e uma destinação final mais adequada (Brasil, 2010c).

Os duas diretrizes instituídas pela Lei - a responsabilidade compartilhada e a logística reversa - são estratégicas para a implantação de um consumo sustentável e um modelo de produção que possa trazer benefícios ao meio ambiente; apesar disso, eles ainda não foram implantados definitivamente, não sendo possível avaliar o seu impacto.

\subsection{Saúde e Segurança em Cooperativas de Triagem}

A proteção à saúde do trabalhador foi estabelecida na Constituição Federal de 1988, fundamenta a regulamentação da divisão do meio ambiente, segurança e saúde do trabalhador, com a finalidade de reduzir os riscos inerentes ao trabalho por intermédio de normas de saúde, higiene e segurança (Brasil, 1988, art. $7^{\circ}$, inciso XXII). Na Constituição Brasileira, as Normas Regulamentadoras (NR) tratam dos requisitos e procedimentos relativos à saúde, higiene e segurança no trabalho (Brasil, 1988, art. 155, Inciso I).

A atenção integrada em Saúde do Trabalhador (ST) inclui ações envolvendo assistência, promoção, vigilância e prevenção dos agravos

\footnotetext{
${ }^{8}$ A logística reversa é um instrumento de desenvolvimento econômico e social caracterizado por um conjunto de ações, procedimentos e meios destinados a viabilizar a coleta e a restituição dos resíduos sólidos ao setor empresarial, para reaproveitamento, em seu ciclo ou em outros ciclos produtivos, ou outra destinação (Brasil, 2010c).
} 
relacionados ao trabalho. O campo da ST constitui-se como espaço interdisciplinar e pluri-institucional, devido aos diversos tipos de profissionais e locais de atendimento, que agem coletivamente, procurando compreender o trabalho e suas condições como um dos principais determinantes sociais da saúde. No entanto, acidentes e doenças originadas nos processos de trabalho persistem (Costa et al., 2013).

A Consolidação das Leis do Trabalho (CLT) identifica em seu artigo 189 as áreas de atividade econômica e a atividade do trabalhador no que diz respeito à insalubridade e à periculosidade, as quais, por sua natureza, condições ou meios de trabalho, expõem os trabalhadores a agentes nocivos, acima dos limites de tolerância fixados em razão da natureza, da intensidade do agente e do tempo de exposição aos seus efeitos (Moura, 2010).

A magnitude de exposição aos riscos ocupacionais em cooperativas de triagem ainda não foi reconhecida por políticas públicas, apenas são identificados os diversos riscos a que estão expostos os catadores durante o manuseio, acondicionamento e armazenamento dos RS, por meio de visitas in loco em trabalhos academicos.

A literatura aponta que os catadores estão inseridos em uma comunidade de risco (Calderoni, 1999). Uma profissão semelhante à dos catadores é a dos coletores de lixo, conhecidos como garis. A coleta de lixo urbano é considerada insalubre em grau máximo, envolvendo agentes biológicos conforme a Norma Regulamentadora $n^{0} 15$. Os catadores são vulneráveis a problemas de saúde do mesmo modo que os garis (Moura, 2010), entretanto cada tarefa em uma cooperativa possui riscos diferentes, específicos para cada tarefa, dependendo do processo produtivo ocupacional. 
Quanto aos trabalhadores de cooperativas, um marco importante foi o I Encontro das Cooperativas de Trabalho das Américas, realizado no Brasil em 28 e 29 de novembro de 1998, que contemplou a saúde e segurança no trabalho dos cooperados, propondo que os sócios de uma cooperativa devem considerar as normas trabalhistas de ordem pública no que tange ao exercício de suas atividades: dignidade, segurança, saúde e medicina do trabalho (OIT, 2001).

No caso das cooperativas de trabalho, a identificação das obrigações a seguir depende da análise da legislação específica sobre segurança e saúde no trabalho (Normas Regulamentadoras (NR), portarias, dentre outras), combinadas às peculiaridades das atividades desempenhadas por cada cooperado. Recomenda-se que a cooperativa busque orientação com profissionais especializados, como engenheiros, técnicos de segurança do trabalho, entre outros, acerca de quais normas devem ser seguidas de acordo com a atividade desenvolvida (Brasil, 2012). Até o momento não há consenso sobre as normas regulamentadoras a que as cooperativas de triagem devem se enquadrar.

Revisando as NR do trabalho vigentes no Brasil a fim de identificar quais podem ser adaptadas às cooperativas de triagem para contribuir com a integridade da saúde dos catadores, mencionou-se a NR n 9, que diz respeito aos agentes físicos, biológicos e químicos; a NR $n^{0} 11$, que diz respeito a normas de segurança de transporte, movimentação, armazenagem e manuseio de materiais, e a NR $n^{\circ} 17$, que diz respeito ao posto de trabalho e ao modo de executar a tarefa (Souza, 2014). 
A NR n 9 trata do Programa de Prevenção de Riscos Ambientais (PPRA), por meio de antecipação, reconhecimento, avaliação e controle da ocorrência de riscos ambientais existentes no ambiente de trabalho. Consideram-se como fatores de risco os "agentes físicos, químicos e biológicos" existentes nos ambientes de trabalho, os quais, em função de sua natureza, concentração ou intensidade e tempo de exposição, são capazes de causar danos à saúde do trabalhador (Brasil, 2006). Ela não define um ramo de atividade, mas deixa claro que é obrigação de todos os empregadores e instituições que admitam trabalhadores como empregados. A última atualização da NR no 9 ocorreu no ano de 1994.

Nas cooperativas de triagem estão os agentes físicos como ruído, iluminação e temperatura. Os agentes químicos são poeira, lâmpadas, chapa de RX, pilhas, baterias e resíduos químicos. Os agentes biológicos são bactérias, fungos, vírus, parasitas e protozoários, entre outros. O contato com os agentes químicos e biológicos ocorre em geral por meio de resíduos descartados de maneira imprópria pela população e pela armazenagem com os resíduos sólidos secos.

A Norma Regulamentadora $n^{\circ} 11$ diz respeito aos equipamentos utilizados na movimentação de materiais, tais como carrinhos de mão e empilhadeiras, entre outros. As normas de segurança para operação dos carrinhos de mão orienta sobre proteção nas mãos e correto deslocamento da carga. Orienta sobre carga máxima suportada pela empilhadeira e sinalização de advertencia sonora quando engata a ré. Em relação ao armazenamento do material, indica que deve ser disposto de forma a permitir a visualização do 
trânsito, da iluminação e do acesso à saída de emergência (Brasil. Ministério do Trabalho e Emprego, 2004).

A Norma Regulamentadora $n^{0} 17$ diz respeito à ergonomia (Brasil. Ministério do Trabalho e Previdência Social, 2002) e menciona diretrizes sobre condições para execução do processo de trabalho. Não define especificamente um ramo de atividade de trabalho, mas condições de trabalho, incluindo aspectos relacionados ao levantamento, transporte e descarga de materiais; mobiliário; aos equipamentos e às condições ambientais do posto de trabalho, e à própria organização do trabalho a ser compreendida de acordo com cada posto de trabalho, deixando claro que essa NR pode ser seguida por qualquer atividade profissional.

No presente estudo, será usada a Norma Regulamentadora nº 17 como referencia para demandar as condições e a organização que estão inseridas no processo de trabalho. Nesta NR, a organização do trabalho diz respeito ao modo de produção; ao modo operatório; à exigência de tempo; ao ritmo de trabalho; ao conteúdo das tarefas, que se referem às exigências de carga estática (parada) ou dinâmica (movimento) dos músculos durante a atividade desenvolvida, e em quais partes do corpo essas exigências ocorrem, tais como pescoço, ombros, dorso e membros superiores e inferiores. Também salienta observar todo e qualquer sistema de avaliação de desempenho para efeito de remuneração e vantagens de qualquer espécie, devendo levar em consideração as repercussões sobre a saúde dos trabalhadores, e orientar a inclusão de pausas para descanso.

Considerando todas as NR citadas anteriormente, é possível propor orientações adaptadas às tarefas desenvolvidas nas cooperativas de triagem. 


\subsection{Os catadores e os riscos no ambiente de trabalho}

Os catadores, considerados agentes fundamentais no processo da logística reversa, participam da coleta seletiva, contribuindo assim para a redução dos custos com a coleta e para a disposição adequada desses resíduos, postergando o tempo de vida útil dos aterros sanitários, ao mesmo tempo buscam suprir a produção industrial manufatureira, com repercussão na preservação de matérias-primas. No entanto, sua inclusão social e econômica na PNRS não tem promovido condições dignas de trabalho e renumeração. Eles ainda trabalham em condições precárias, com equipamentos muitas vezes inadequados, espaço físico insalubre, contato com os resíduos sólidos contaminados por resíduos orgânicos ou produtos químicos, além de manejo que envolve risco à saúde.

Consideram-se riscos ambientais os agentes físicos a que os catadores estão expostos em seu ambiente de trabalho, como o ruído excessivo de alguns equipamentos, temperatura e luminosidade, além da exposição a intempéries (Velloso et al., 1997).

Os agentes químicos podem ser encontrados em uma variedade de resíduos químicos, dentre os quais merecem destaque (pela presença mais constante): pilhas e baterias; óleos e graxas; pesticidas/herbicidas, solventes; tintas; produtos de limpeza; cosméticos; remédios; aerossóis e lâmpadas (Ferreira e Anjos, 2001). Uma significativa parcela desses resíduos é classificada como perigosa por apresentar metais pesados, como chumbo, cádmio e mercúrio, os quais podem ter efeitos deletérios à saúde humana 
quando incorporados à cadeia biológica. Os efeitos cumulativos desses produtos podem provocar diversas doenças, como saturnismo e distúrbios do sistema nervoso, entre outras (Ferreira e Anjos, 2001)

Já os agentes biológicos presentes nos resíduos sólidos podem ser responsáveis pela transmissão de doenças. Os microrganismos patogênicos ocorrem nos resíduos sólidos mediante a presença de lenços de papel, curativos, fraldas descartáveis, papel higiênico, absorventes, agulhas e seringas descartáveis e preservativos (Collins e Kennedy, 1992; Ferreira, 1997), expondo os catadores a objetos perfuro cortantes e contaminação biológica. A poeira depositada entre os resíduos pode levar a problemas respiratórios e pulmonares (Carranza et al., 2002; Ferreira e Anjos, 2001). Mordidas de animais (cães, ratos) e picadas de formigas também podem ocasionar enfermidades de tipo infeccioso, parasitário ou alérgico (Ferreira, 1997).

Os fatores de riscos biomecânicos, como as cargas físicas, que tem exigência de esforço físico, movimentos repetitivos, levantamento de peso, postura inadequada e postura estática, quando presentes no ambiente de trabalho, podem originar afecções musculoesqueléticas e levando a queixas dolorosas em um determinado tempo (NIOSH, 1997; Anjos e Ferreira, 2000).

Danos osteomusculares têm gerado altos encargos trabalhistas e previdenciários ao Instituto Nacional de Seguro Social (INSS) e ao setor produtivo. Fazendo surgir vários estudos sobre as causas de adoecimento, investigando a biomecânica do movimento e a exposição a fatores de risco do trabalho. Hoje já é possível conceber um contexto geral de ocorrência dos fatores de exposição mais frequentes nas tarefas desenvolvidas em diversos 
ramos de atividade, o que tem possibilitado a adoção de medidas preventivas em nível nacional (Ministério da Saúde, 2012).

No Brasil, uma medida fundamentada pelo Ministério do Trabalho e da Previdência Social instituída pela Portaria n. o 3751/90, foi o estabelecimento da Norma Regulamentadora $n^{\circ}$ 17, que tem como princípio "estabelecer parâmetros que permitam a adaptação do trabalho às condições e características psicofisiológicas dos trabalhadores, de modo a proporcionar um máximo de conforto, segurança e desempenho eficiente" (Brasil. Ministério do Trabalho e Previdência Social, 2002, p. 4)

Verifica-se que a maior parte dos estudos sobre catadores tem abordagens sociais e psicossociais das questões sociopolíticas (gênero, movimento social, organização e reconhecimento social dos catadores) e análises técnicas dos sistemas integrados de gestão em resíduos sólidos urbanos, visando ao domínio ambiental e sanitário (Oliveira, 2010).

Em vários estudos com catadores (autônomos), catadores de rua (gari) que trabalham em algum órgão público e os poucos com catadores (cooperados) eles consideram seu trabalho pesado, realizado com posturas incômodas, repetitivos e referem algum tipo de dor/desconforto osteomuscular, sendo a região das costas e os membros superiores os mais referidos na maioria desses estudos (Ferreira et al., 2001; Porto et al., 2004; Madruga, 2002; Silva et al., 2007; Maccarini e Hernández, 2007; Alencar et al. (2009); Alexandrino et al., 2009; Jesus et al., 2012; Bazo et al., 2011; Castilhos Junior et al., 2013, Parra et al., 2015). E reconhecem seus fatores de risco no trabalho (Velloso et al., 1998; Ferreira e Anjos,2001; Silva et al., 2004; Dall'Agnol e Fernandes (2007); Gutberlet et al., 2016; Hoefel et al., 2013). 
Portanto, o trabalho que envolve a manipulação dos RS apresentou riscos ocupacionais em diversos estudos devido às condições de trabalho e aos fatores de exposição que estão presentes.

\subsection{Produção do catador como força de trabalho}

Existem diversas maneiras de medir a produção do catador. Seja por hora, por dia, por mês ou por peso de MR, essa produção também pode ser avaliada individualmente ou coletivamente. A maneira de medir a produção depende do sistema que cada cooperativa estabelece, levando em consideração o tipo de tarefa. Em relação aos materiais rejeitados eles não são incluídos ao se medir a produção, mesmo o catador tento despendido tempo e força de trabalho com esses materiais.

Vale ressaltar que a produtividade dos catadores não depende exclusivamente deles, mas de toda a cadeia produtiva, desde a produção de bens, consumo, descarte de RS adequados, localidade do roteiro da coleta, sazonalidade, tipo de coleta e estrutura da cooperativa. O faturamento das cooperativas depende exclusivamente da comercialização dos materiais, que muitas vezes dependendo da situação, em conseguir um maior ou menor valor reflete diretamente na renda dos catadores, levando a desmotivação e a conflitos internos quando os preços de venda estão reduzidos.

Geralmente os catadores se adaptam às condições de trabalho e adquirem mecanismos próprios a partir dos conhecimentos, experiências e habilidades que possuem e os conduzem à realização da sua tarefa. De 
alguma maneira eles realizam a tarefa estabelecida e garantem sua produtividade.

Condições multifatoriais (biomecânicas e organizacionais), aspectos fisiopatológicos, interações psicológicas e sociais contribuem para a ocorrência de dor, sendo muitas vezes entendida de forma subjetiva (Teixeira et al., 2001). É fundamental que os catadores percebam e avaliem as situações às quais estão expostos durante a atividade profissional e que tais situações podem resultar em algum tipo de morbidade osteomuscular.

A produção diária nas cooperativas acontece na tarefa de coleta porta a porta, na tarefa de triar e prensar. A produtividade dos catadores é avaliada em três momentos distintos: primeiramente quando os materiais coletados chegam à cooperativa, após serem triados e finalmente quando ele é prensado.

Na coleta porta a porta, a produção é medida pelo peso que o catador coletou durante o roteiro. Ele necessita acondicionar os sacos em um único local em cada rua que o veículo passa para facilitar o lançamento dos mesmos. Porém, muitas vezes o descarte dos RS está impróprio, sacos com excesso de peso, sacos abertos e RS no chão. Ainda, são circunstâncias que interferem na produtividade do coletor como: modo de separação na fonte geradora, cachorros soltos, tipo de trânsito e intempéries.

A triagem envolve uma separação fragmentada de subtipos de resíduos sólidos, ou seja, são separados por cor, espessura, tamanho, tipo de composição e peso. Esses resíduos vão sendo armazenados um a um nos bigbags (sacolas de ráfia) ou barricas. A produção de um catador pode variar de 500 kg/dia a 700 Kg/dia, com uma jornada de oito horas (São Paulo (Estado), 2005). 
Na prensa, a produtividade do catador é calculada pelo peso do fardo de cada subtipo de material e pela quantidade de fardos que ele consegue produzir no dia. A prioridade na prensagem acompanha a quantidade de materiais já comercializados ou que está a mais tempo acumulado, ou RS volumosos que ocupam espaço físico maior, como é o caso dos papelões.

Nas demais tarefas não ocorrem a contagem de produção, como a tarefa de apoio no galpão, administrativa, desmontagem de REEE, liderança e limpeza.

Os catadores têm consciência sobre o benefício coletivo em aproveitar o maior número possível de materiais, uma vez que toda a cooperativa é favorecida com essa iniciativa, por dispor de maior quantidade e qualidade de materiais (Brasil, 2008).

Em estudo do Ministério do Desenvolvimento Social e Combate à Fome e MNCR (2006), realizado em 20 cooperativas, foi observada uma produtividade de $37 \mathrm{~kg} / \mathrm{catador} / \mathrm{dia}$ em nove cooperativas, consideradas cooperativas de baixa eficiência; 58 kg/catador/dia em oito cooperativas, consideradas cooperativas de média eficiência, e 84 kg/catador/dia em três cooperativas, consideradas cooperativas de alta eficiência. A média ponderada encontrada foi de $53 \mathrm{~kg} / \mathrm{catador} / \mathrm{dia}$.

O Manual - Plano de Gestão de Resíduos Sólidos "Indicadores de produtividade para catadores em galpão "apresenta outros resultados de produtividade, com quantidade coletada de $160 \mathrm{~kg} / \mathrm{dia}$, triada de $200 \mathrm{~kg} / \mathrm{dia}$ e prensada de 600 kg/dia (BRASIL. MMA, ICLEI, 2012, p.101). A quantidade triada e prensada de resíduos ultrapassa a coletada. 
As condições de comercialização dos materiais para as indústrias de transformação têm sido consideradas um fator negativo na atividade das cooperativas. A dependência de intermediários foi apontada na literatura como o maior entrave para a ascensão dos catadores na cadeia de valor da reciclagem, ou seja, a venda direta das cooperativas para as indústrias. As cooperativas muitas vezes necessitam agrupar sua produção com outras cooperativas ou em rede para obter melhor preço dos materiais e não se tornarem refém dos intermediários (empresas de compra e venda dos MR)(CEADEC, 2017).

Outra condição que influencia no preço MR é o estado que chegam esses materiais, quanto à contaminação, a composição dos fardos por um único tipo de MR e a integridade dos fardos armazenados, podendo aumentar ou reduzir os preços.

Um fator agravante vivenciado rotineiramente pelos catadores é o grande volume de materiais rejeitados que chegam à cooperativa, esses materiais são coletados impreterivelmente nos dias da coleta seletiva, por estarem misturados com os RSU. Acaba fazendo parte de todo o processo produtivo, são descarregados, separados, armazenados em big-bag no final da esteira e transportados até o pátio externo da cooperativa, tornando dispendioso para os catadores e sem nenhum ganho adicional sobre este trabalho, por não possuírem valor de comercialização. Os materiais rejeitados são coletados uma vez por semana pela Prefeitura e destinados a aterros. 


\subsection{Estudos de Morbidade Osteomuscular em Catadores de Materiais Recicláveis}

O trabalho é elemento integrante da vida do indivíduo, possibilitando a construção de uma identidade não apenas profissional como pessoal, além de ser meio de reconhecimento e de valorização social. A profissão de um indivíduo caracteriza o seu modo de vida (Medeiros e Macedo, 2007), contudo, reflete sobre sua saúde.

A revisão bibliográfica sobre o tema proporcionou conhecimento sobre as morbidades que afetam os catadores de materiais recicláveis em cooperativas de triagem e que autorreferiram dor/desconforto osteomusculares.

Como mencionado anteriormente, estudos que abordam a organização do trabalho, perfil de morbidade e relatos de sintomas osteomusculares em trabalhadores abrangem diversas categorias profissionais, mas estudos com catadores de materiais recicláveis que trabalham em cooperativas foram escassos, sendo apenas seis que discutiram sintomas osteomusculares autorreferidos (Silva et al., 2007; Maccarini e Hernández, 2007; Alencar et al., 2009; Jesus et al., 2012; Bazo et al., 2011; e Castilhos Junior et al., 2013); esses estudos foram compostos por amostras com catadores autônomos e/ou cooperativados e/ou garis, mesmo compostos por amostras diversificadas de alguma forma envolveram o foco desse estudo, a presença de dor osteomuscular relacionada às condições de trabalho.

Silva et al. (2007) realizam pesquisa com 455 catadores autônomos ou de cooperativas sobre sintoma de dor no joelho e a relação do sintoma com as 
condições de trabalho. O instrumento de coleta de dados foi formulado pelos autores, contendo perguntas estruturadas e semiestruturadas. Esses catadores relataram gonalgia, em torno de $20 \%$ (91), e foi constatado um risco ocupacional para afecções nos joelhos de $50 \%$ (45) entre os que referem dor.

Maccarini e Hernández (2007), fizeram um estudo como propósito de analisar a quantidade armazenada e o preço dos resíduos e, quais os locais de beneficiamento do material coletado, como central de triagem ou sucateiros. Os dados coletados abrangiam questões sobre a organização do processo de reciclagem e as condições de trabalho. Observaram também que os catadores trabalhavam em condições precárias, levando ao acúmulo de materiais recicláveis a ser triados. Os catadores relataram a tarefa cansativa e a presença de dor na coluna foi apontada por todos os catadores. A quantidade de catadores não foi mencionada.

Em 2009, Alencar et al., fez um trabalho com 22 catadores cooperativados sobre sinais e sintomas autorreferidos relativos aos trinta dias que antecederam a investigação, encontram prevalência de dor musculoesquelética em 90,9\% ( $n=20)$, a região mais afetada foi a coluna lombar. Também aparecem relatos de cansaço físico em 95,5\% ( $n=21)$, dor de cabeça em 81,8\% ( $n=18$ ), erupções cutâneas em 27,3\% ( $n=6)$, indigestão em 45,5\% ( $n=10)$, gastrite em 36,4\% ( $n=8)$, insônia em 27,3\% ( $n=6)$, dificuldade de concentração em 45,5\% (n=10), e oscilação de humor em 63,6\% ( $n=14)$.

Em 2011, Bazo et al. investigaram as condições de trabalho, a postura e o perfil sociodemográfico e a incidência de dor em 18 catadores em uma cooperativa do Paraná. Para a incidência de dor, foi utilizado uma figura do corpo humano dividida em coluna cervical, membros superiores, coluna dorsal 
e lombar e membros inferiores. Esses catadores apresentam prevalência de dor na coluna cervical e membros superiores na proporção de 50\% (9); na coluna dorsal, 65\% (12); na coluna lombar e membros inferiores, 60\% (11), sendo essas as regiões do corpo que mais incomodavam tais trabalhadores.

Em 2012, Jesus et al., realizaram um estudo com uma amostra de 96 catadores que trabalham nas ruas ou em cooperativas com o objetivo de avaliar sua qualidade de vida. O estudo utilizou o questionário WHOQOL-100, é um instrumento composto de 100 questões que avalia a qualidade de vida, dividido em seis domínios: físico, psicológico, nível de independência, relações sociais, ambiente e espiritualidade e/ou crenças pessoais. Constataram dores corporais, problemas osteoarticulares, hipertensão e nervosismo nos domínios físico e psicológico, não havendo diferenças significativas quando comparados com a população de controle.

Castilhos Junior et al. (2013) investigam 29 cooperativas para analisar a infraestrutura e as condições de trabalho de 236 catadores de materiais recicláveis, abrangendo as regiões Sul, Sudeste e Nordeste do Brasil. O questionário da entrevista semiestruturada aplicado aos catadores é composto de 30 perguntas, algumas baseadas em trabalhos anteriores e outras elaboradas pelos próprios pesquisadores. Os dados apresentam maior incidência de sintomas osteomusculares na região das costas, com proporção de $38,5 \%$. Dos catadores participantes, 97 foram entrevistados in loco pelo próprio pesquisador e 139 participantes responderam a um questionário enviado por correspondência e tiveram a entrevista realizada pelo dirigente da cooperativa. 
Os efeitos cumulativos de exposição aos riscos ergonômicos no sistema osteomuscular em trabalhadores favorecem a lesões. Com a finalidade de facilitar o entendimento e a avaliação dessas lesões se deu o nome de Lesões por Esforços Repetitivos (LER) e Distúrbios Osteomusculares Relacionados ao Trabalho (DORT). Devido à quantidade de afastamentos de trabalhadores por relatos de desconforto osteomuscular em 2012, a Secretaria de Vigilância em Saúde Ambiental e do Trabalhador realizou mais uma revisão da Instrução Normativa INSS/DC $n^{\circ} 98$ que diz respeito aos sintomas dos Distúrbios Osteomusculares Relacionados ao Trabalho, pelo Ministério da Saúde. No intuito de atender as necessidades de trabalhadores com suspeita de agravos à saúde relacionados ao trabalho foram elaborando instrumentos para generalizar as afecções, os sintomas e as possíveis causas e associá-las a profissão do trabalhador (Ministério da Saúde, 2012).

DORT é uma síndrome relacionada ao trabalho, caracterizada pela ocorrência de um conjunto de sintomas concomitantes ou não, tais como dor, parestesia, sensação de peso, fadiga, de aparecimento insidioso, geralmente nos membros superiores, mas podendo acometer membros inferiores (Ministério da Saúde, 2012).

A dor é um dos sintomas incluídos nos distúrbios e afecções musculoesqueléticas, definida como uma experiência sensorial e subjetiva, podendo ser isolada ou associada a outras condições patológicas, tende a levar a incapacidade quanto maior for à perda das capacidades funcionais em sua atividade laboral e das atividades de vida diária. No sistema musculoesquelético tende ao enfraquecimento, hipertrofias, contraturas 
viciosas levando a má postura, ao longo do tempo degenerações articulares e em casos mais agravantes a osteoporose (Calia e Vieira, 2001).

Os riscos osteomusculares de exposição ocupacional são difíceis de caracterizar e quantificar em função da diversidade das variáveis envolvidas na tarefa do trabalho, muitas das quais possuem natureza subjetiva. Compreendem de modo geral tarefas que combinam movimento repetitivo, ritmo intenso e postura inadequada que contribuem para o surgimento desse tipo de agravo (Egri, 1999).

Segundo Maciel (1998), os fatores de risco para o surgimento de doenças osteomusculares predominam nas tarefas manuais que exigem movimentos rápidos e em curtos períodos de tempo, potencializados pelo movimento repetitivo, intensificação do ritmo imposto pela produtividade e mediante escassez na diversificação das tarefas; além de outros fatores de ordem organizacional e psicossocial, quando a conjugação de estresse e conflitos interpessoais podem estar presentes.

Por meio do relato de sintomas e análise ergonômica do trabalho, em um estudo com cabelereiras, Mussi (2005) reforçou as conclusões descritas em outros estudos sobre riscos profissionais, em que fatores de risco ocupacionais associados ao desenvolvimento de LER/DORT são identificados como biomecânicos, organizacionais e psicossociais, fazendo parte do contexto de predisposição a doenças ocupacionais.

Os fatores de risco não são independentes, interagem entre si e devem ser sempre analisados de forma integrada. Envolvem aspectos biomecânicos, cognitivos, sensoriais, afetivos e de organização do trabalho. Na maioria das 
vezes os fatores são identificados por meio de observações empíricas e confirmados com estudos epidemiológicos (Kuorinka e Forcier, 1995).

Exigências da tarefa, às vezes impostas de maneira descontrolada e desprovida de apoio organizacional, desencadeiam soluções poucos eficazes e improvisações de caráter emergencial (Cordeiro et al., 2008), o que acaba, em muitos casos, constituindo uma fonte de riscos ocupacionais. 

3. Objetivos 



\section{Objetivos}

\subsection{Objetivo Geral}

Constitui objetivo geral deste estudo identificação das características das cooperativas de triagem, das condições sociodemográficas, do ambiente de trabalho e da morbidade referida para distúrbios osteomusculares em catadores de materiais recicláveis em cooperativas da Região Metropolitana de São Paulo.

\subsection{Objetivos Específicos}

- Apresentar a história laboral;

- Apresentar as percepções dos catadores sobre as condições físicas e organizacionais da cooperativa de triagem;

- Estimar a prevalência de dor/desconforto osteomuscular relacionados ao trabalho nos 12 meses que antecederam a realização da pesquisa;

- Caracterizar as regiões anatômicas mais acometidas;

- Identificar os riscos biomecânicos. 

4. Métodos 



\section{Métodos}

\subsection{Delineamento do Estudo}

Este é um estudo transversal (Rothman et al., 2009), com coleta de dados sobre morbidade osteomuscular autorreferida, realizada concomitantemente ao levantamento sobre a presença de fatores de exposição à morbidade nas condições de trabalho.

\subsection{Período}

Este estudo ocorreu entre os meses de agosto e dezembro de 2015. Foi realizado em parceria com o Movimento Nacional dos Catadores de Materiais Recicláveis (MNCR), como parte do projeto Catadores de Materiais Recicláveis: Saúde, Trabalho e Meio Ambiente.

\subsection{Amostra}

Este estudo foi realizado por amostragem de conveniência não probabilística, considerando-se que não existem dados precisos acerca do número de cooperativas e de catadores na Região Metropolitana de São Paulo (Levy e Lemeshow, 1980) e as cooperativas selecionadas apresentaram facilidade de acesso regional. 
O estudo foi realizado em quatro Cooperativas de Materiais Recicláveis da Região Metropolitana de São Paulo com 250 catadores, com participação de todos que estavam presentes no dia da coleta de dados. Todas as cooperativas pesquisadas são cadastradas no MNCR e têm parceria com a Prefeitura de São Paulo e Prefeitura Municipal de Guarulhos para coleta seletiva. Essas cooperativas são parte da amostra da tese de doutorado de Souza (2015), intitulado Avaliação ambiental nas cooperativas de materiais recicláveis e na tese de doutorado de Ferron (2015), com o título Saúde, trabalho e meio ambiente: exposição a metais em catadores de materiais recicláveis.

\subsection{Instrumentos}

Foi utilizado o Questionário Nórdico de Sintomas Osteomusculares (Pinheiro et al., 2002) (Anexo I), o qual apresenta um questionário padronizado sobre sintomas osteomusculares autorreferidos, com pelo menos um episódio, nos últimos 12 meses anteriores a investigação. Tem o objetivo de padronizar informações sobre a região anatômica acometida e os tipos de sintomas; mensurar o tempo do início do problema, a frequência do sintoma e uma escala de desconforto conforme a percepção do trabalhador (Anexo I).

As perguntas referentes às condições de trabalho foram coletadas conforme questionário utilizado em estudo de Mussi (2005) e adaptadas aos catadores. 


\subsection{Aspectos Éticos}

Projeto aprovado pela Comissão de Ética para Análise de Projetos de Pesquisa - CAPPesq, da Diretoria Clínica do Hospital das Clínicas e da Faculdade de Medicina da Universidade de São Paulo (Anexo III) com o título: Condições de Trabalho e Morbidade Referida para Distúrbios Osteomusculares em Catadores de Materiais Recicláveis.

Foi apresentado o Termo de Consentimento Livre e Esclarecido para todos os trabalhadores em situação anterior ao início da coleta de dados e foram esclarecidos os objetivos do estudo. Cada catador ratificou de forma voluntária a sua anuência em participar. Todos assinaram o termo em momento anterior ao início da coleta de dados. A condição da pesquisa, como confidencialidade dos dados e colaboração no estudo, não levaria os catadores a ter acesso aos ambulatórios de especialidades ortopédica ou neurológica do Hospital das Clínicas. Tudo foi explicado verbalmente. Foi salientado que eles poderiam retirar seu consentimento a qualquer momento e deixar de participar da pesquisa.

\subsection{Tipos de variáveis do estudo}

\subsubsection{Variável dependente}

A variável dependente deste estudo foi à ocorrência de dor/desconforto osteomuscular relacionados ao trabalho nos 12 meses que antecederam o estudo, conforme a questão E1 do questionário (não/sim) (Anexo I). 


\subsubsection{Variáveis independentes}

Foram coletadas as características sociodemográficas como sexo, idade, raça, procedência, escolaridade e contribuição para o INSS.

Quanto às características da história laboral, foi investigado se o catador trabalhou em outra ocupação anteriormente e o tempo de trabalho como catador.

Em relação às atividades profissionais e às condições de trabalho foi considerada a percepção dos catadores em relação à exposição de repetitividade, sobrecarga, postura de trabalho, monotonia, rodízio, pausas, contagem de produção, condições de luminosidade, de ruído e térmica, ocorrência de acidente de trabalho; satisfação e realização no trabalho. Estas variáveis são consideradas como principais fatores de risco para distúrbios osteomusculares (Brasil. Ministério do Trabalho e Previdência Social, NR. $n^{\circ}$ 17, 2002; NIOSH, 1997). As demais variáveis (C1, C2, C5, C7, C8, C11, C12, C14 e C15) sobre organização do trabalho e fatores psicossociais não foram analisadas, por serem semelhantes às variáveis estudas.

\subsection{Critérios de inclusão e exclusão do catador}

\subsubsection{Critérios de inclusão}

Os critérios considerados para incluir um trabalhador no estudo foram (a) concordar e assinar o Termo de Consentimento Livre e Esclarecido (Anexo II); (b) estar atuando unicamente na atividade laboral de catador na cooperativa; (c) possuir idade maior de 18anos e (d) não referir antecedente de morbidade 
diagnosticada e/ou submissão a cirurgia ortopédica ou neurológica de membros superiores, coluna e membros inferiores.

\subsubsection{Critérios de exclusão}

Foi considerada cláusula de exclusão a detecção por parte do entrevistador, ou menção pelo catador, de distúrbio físico-cognitivo com potencial para prejudicar o juízo na decisão de colaborar com a pesquisa ou responder adequadamente o questionário.

\subsection{Método de revisão bibliográfica}

O levantamento de estudos sobre a morbidade osteomuscular autorreferida em catadores de cooperativas de reciclagem foi realizado nas bases de dados Medline e Lilacs. Medline é a principal base de dados da Biblioteca Nacional de Medicina dos Estados Unidos e inclui todas as referências do Index Medicus. A Lilacs é uma base de dados de alcance latinoamericano.

Inicialmente, a busca ocorreu por descritores mais genéricos relacionados à temática em estudo, como ragpickers, street-sweepper, garbage, wastecollectors. A seguir, foram identificados termos correlatos e sinônimos: recyclable, collective, refuse e waste. Foram investigados descritores específicos como musculoskeletal, muscular system disorders, symptoms musculoskeletal e injuries, nas diferentes bases de dados e nos mais variados periódicos. Em todas as buscas, os descritores foram conciliados 
a partir de combinadores lógicos (and, or, not) com o objetivo de delimitar e aperfeiçoar a bibliografia selecionada.

Foram rastreadas as páginas da rede eletrônica de internet que versavam sobre o trabalho do catador, páginas de vigilância em saúde do trabalhador, do Movimento Nacional dos Catadores de Materiais Recicláveis, a página da Previdência Social e a página do Nacional Institute for Occupational Safety and Health (NIOSH), a política nacional de resíduos sólidos e seus instrumentos, publicações difundidas por associações e organizações não governamentais (ONGs), por conterem informações relevantes sobre o tema e disponibilizar publicações censitárias.

Conjuntamente, foram reunidas publicações da Região Metropolitana de São Paulo de circulação dirigida, difundidas na mídia eletrônica e impressa sobre resíduos sólidos e catadores.

Foram encontrados 21 artigos entre os anos de 2007 a 2014 que apresentavam em sua amostra os descritores "catadores autonomos", "cooperativados", ou "garis", relacionando-os com os descritores "condições de trabalho", "riscos ocupacionais", "acidente de trabalho", "problemas de saúde" e "dor osteomuscular". Foram eliminados dez artigos, cujas amostras apresentaram apenas "catadores autonomos" ou "garis", e cinco artigos que não relataram a presença de "dor osteomuscular".

\subsection{Trabalho de campo}

Com o propósito de conhecer a organização dos trabalhadores em cooperativa de reciclagem, foram levantadas as instituições que poderiam 
representá-los, chegando-se até o contato com o Movimento Nacional dos Catadores de Materiais Recicláveis (MNCR).

A partir da informação sobre as cooperativas cadastradas no MNCR, foram levantados dados sobre a localização, telefone de contato, nome do representante da cooperativa, número estimado de trabalhadores, tipos de materiais recicláveis e cadastro no programa de coleta seletiva. Em seguida foi apresentada a proposta da pesquisa ao representante da MNCR, da RedeCataSampa $^{9}$ e os pesquisadores envolvidos no projeto Catadores de Materiais Recicláveis: Saúde, Trabalho e Meio Ambiente. Após isso foi realizado um encontro com os catadores, representantes do MNCR e pesquisadores, no Departamento de Medicina Preventiva da Faculdade de Medicina da Universidade de São Paulo, que teve duração de um dia, com o objetivo de conhecer o que os catadores entendiam sobre o tema saúde (Mandeli, et al, 2013).

Na sequência, foram realizadas três reuniões da pesquisadora com os representantes do MNCR para apresentar a proposta de pesquisa e préseleção das cooperativas que iriam participar do estudo.

Cumprida esta etapa, iniciaram-se visitas às cooperativas, sempre na companhia de representantes do MNCR e da RedeCataSampa, totalizando dez visitas, sendo estas: 01- Nova Esperança, 02- Cooperativa Central Tiete, 03CORA - Cooperativa de Reciclagem de Arujá, 04- Coopere, 05- Coopermape, 06- Coopereciclável, 07-Avemare, 08- Cooperação, 09- Coopervivabem e 10-

9 A RedeCataSampa é um Instituto que busca organizar práticas de economia solidária e comercializar os resíduos das cooperativas a ela associadas (Instituto Rede de Base Orgânica Cata Sampa, 2016). 
Coopamare. Destas cooperativas foram selecionadas quatro para coleta de dados.

Posteriormente, o projeto foi apresentado a cada cooperativa selecionada para a coleta de dados, na presença do presidente da cooperativa e um representante do MNCR. Após esta visita de apresentação, o projeto foi levado ao conhecimento dos catadores durante assembleia mensal em cada cooperativa; e, depois da anuência de todos os cooperados, foi marcada uma data para o início do trabalho de coleta de dados.

Os catadores obtiveram uma explicação do propósito e do escopo da pesquisa e foram informados de que ela ocorreria na sede da Cooperativa, durante o horário de expediente, no período da manhã ou da tarde, de segunda-feira a sexta-feira.

No dia da aplicação do questionário foram discutidas dúvidas e recolhido o Consentimento Livre e Esclarecido (anexo II) de cada um dos participantes.

A coleta de dados ocorreu no segundo semestre de 2015 por meio do preenchimento de questionário aplicado exclusivamente pela pesquisadora. Visitas às cooperativas selecionadas foram previamente agendadas com antecedência de pelo menos dez dias.

A pretensão com as visitas foi de capturar informações que pudessem subsidiar a descrição da população de trabalhadores; o funcionamento das cooperativas e as condições ambientais de trabalho, levando em conta a percepção referida dos trabalhadores nos aspectos térmico, luminoso, sonoro, da organização do trabalho em turnos, postura do catador, esforço físico, ocorrência de acidente de trabalho, movimento repetitivo, monotonia, pausas, rodízios, contagem de produção e satisfação pessoal como catador. 
A coleta de dados foi realizada ao lado do catador em seu posto de trabalho no momento em que ele executava sua tarefa e teve início com uma conversa sem a intenção de ir diretamente ao questionário, mas de conquistar a confiança dos catadores, a fim de que as respostas fossem as mais fidedignas possíveis. A partir deste "bate-papo", houve a coleta de dados do questionário semiestruturado (Anexo I), preenchimento do questionário e escuta dos relatos dos sujeitos da pesquisa, quanto à percepção da tarefa que desenvolviam.

\subsection{Tratamento dos dados}

\subsubsection{Consistência dos dados}

Os questionários foram revisados pela pesquisadora no local da coleta com o objetivo de verificar se alguma pergunta havia ficado sem resposta. As perguntas foram transformadas em variáveis codificadas e dispostas em um layout, digitadas no softuare Epidata. A consistência dos dados foi checada por meio do programa Stata 2010, verificando-se o total de respostas obtidas para cada variável correspondia ao total amostral. Em seguida, os resultados foram processados em banco de dados do Microsoft Excel e transportados para o programa estatístico Stata 10 para a realização dos cálculos estatísticos.

\subsubsection{Análise dos dados}

Inicialmente foi realizada a análise descritiva das variáveis coletadas, com o cálculo de proporções e médias, seguidas de algumas agregações de 
respostas de variáveis independentes em uma mesma categoria, com o objetivo de facilitar a análise. Esta necessidade de agrupamento de respostas foi devido à quantidade de respostas em algumas categorias serem insuficientes para análise.

Foi realizada análise estatística univariada, examinando-se cada variável independente com o desfecho do estudo, as variáveis que apresentaram um valor-p inferiores a 0,20 foram ajustadas conjuntamente no modelo múltiplo. No modelo de Regressão Logística (stepwise) as variáveis que não tiveram significância estatística foram sendo retiradas, restando ao final, apenas aquelas com valor-p menor que 0,05.

O modelo de regressão logística foi escolhido devido à variável resposta ser binária, assumindo não e sim, sendo considerado como resposta sim o sucesso, por ser o evento de interesse estudado nesta pesquisa, e as variáveis de explicação (covariáveis), levando-se em conta mais de uma. A cooperativa denominada - D - e a resposta denominada - Não - para as variáveis, foram consideradas como referência para o modelo, exceto para as variáveis rodízios de tarefas, satisfação no trabalho e dor/desconforto foi a resposta denominada - Sim.

Admitiu-se o valor crítico de $p<0,05$, com a chance de ter $5 \%$ de erro aceitável e com o nível de confiança de 95\% (Levy e Lemeshow, 1980).

As variáveis e suas características de respostas são apresentadas no Quadro 2. 
Quadro 2. Variáveis independentes e dependente do estudo e suas características de resposta

\begin{tabular}{|c|c|}
\hline VARIÁVEIS INDEPENDENTES & CARACTERÍSTICAS \\
\hline \multicolumn{2}{|l|}{ DEMOGRÁFICAS } \\
\hline Sexo & Feminino/Masculino \\
\hline Idade & Anos completos \\
\hline Raça & Cor da pele \\
\hline Naturalidade & Região geográfica \\
\hline \multicolumn{2}{|l|}{ SOCIOECONÔMICAS } \\
\hline Escolaridade & $\begin{array}{l}\text { Não alfabetizado/somente alfabetizado } / 1^{\mathrm{a}} \\
\text { a } 4^{\mathrm{a} / 5^{\mathrm{a}}} \text { a } 8^{\mathrm{a}} \text { série } / 2^{\circ} \mathrm{grau} / \mathrm{superior} \text { ou mais }\end{array}$ \\
\hline Contribuição ao INSS* & Não ou Sim \\
\hline \multicolumn{2}{|l|}{ HISTÓRIA LABORAL } \\
\hline Teve outra ocupação & Não ou Sim \\
\hline Tempo como catador & Em anos \\
\hline \multicolumn{2}{|l|}{ CONDIÇÕES DE TRABALHO } \\
\hline Acidente de trabalho & Não ou Sim \\
\hline Postura & Sentada, Em pé ou Alternada \\
\hline Esforço físico na tarefa & Não ou Sim \\
\hline Local de trabalho ruidoso & Não ou Sim \\
\hline lluminação do ambiente & Péssima/ruim/regular e Boa/ótima \\
\hline Temperatura do ambiente & Péssima/ruim/regular e Boa/ótima \\
\hline \multicolumn{2}{|l|}{ ORGANIZAÇĀO DO TRABALHO } \\
\hline Trabalho monótono & Não ou Sim \\
\hline Tarefa repetitiva & Não ou Sim \\
\hline Rodízio de tarefa & Não ou Sim \\
\hline Pausas & Não ou Sim \\
\hline Contagem de produção & Não ou Sim \\
\hline Satisfação e realização pessoal & Não ou Sim \\
\hline \multicolumn{2}{|l|}{ VARIÁVEL DEPENDENTE } \\
\hline $\begin{array}{l}\text { Dor/desconforto osteomuscular nos } \\
\text { últimos } 12 \text { meses que poderia } \\
\text { estar relacionado com o trabalho }\end{array}$ & $\begin{array}{l}\text { Não ou Sim, qual parte do corpo, } \\
\text { membros superiores e/ou coluna lombar } \\
\text { e/ou membros inferiores }\end{array}$ \\
\hline
\end{tabular}

NOTA: INSS - Instituto Nacional do Seguro Social

Consideraram-se também variáveis relativas à possível exposição a riscos ocupacionais e/ou agravos à saúde, como cargas mecânicas, fisiológicas e psíquicas, movimentos repetitivos, sobrecarga, postura inadequada, falta de rotatividade e pausa (Brasil, Ministério do Trabalho, 2002), produtividade, monotonia e conflitos pessoais (Kompier e Levi, 1994), os quais poderiam ter relação com a rotina diária de trabalho. 



\section{Resultados}





\section{Resultados}

\subsection{Descrição da organização das Cooperativas estudadas}

As cooperativas pesquisadas têm funcionamento médio de treze anos e meio. O surgimento das cooperativas deve-se provavelmente ao Programa de Coleta Seletiva Solidária, que teve início no ano de 2004 (São Paulo (cidade), [2004]).

Três cooperativas (A, B e C) ficavam na cidade de São Paulo, coletavam seus resíduos na Zona Oeste, parte da Norte e da Central. A cooperativa (D) que se localizava no município de Guarulhos realizava a maior parte da coleta na Região Oeste e em alguns bairros considerados produtivos em relação à qualidade dos resíduos, ou seja, conseguiam uma maior quantidade de resíduos aproveitáveis.

As três primeiras cooperativas ( $A, B$ e $C$ ) tinham apenas um turno de trabalho, das $8 \mathrm{~h}$ às $17 \mathrm{~h}$. A quarta cooperativa (D) tinha dois turnos de trabalho: o primeiro das $6 \mathrm{~h}$ às $14 \mathrm{~h}$ e o segundo das $14 \mathrm{~h}$ às $22 \mathrm{~h}$. Horas extras ocorriam na primeira, na segunda e na quarta cooperativa. Na terceira havia trabalhadores que necessitavam retornar a seus locais de repouso com hora marcada por estarem em regime de prisão semiaberto ou em recuperação de dependência química.

Quanto ao recrutamento das pessoas, observou-se variedade em relação à sua procedência. O recrutamento de catadores ocorria entre aqueles 
que sempre trabalharam neste ramo de atividade, trabalhadores que ficaram desempregados e não conseguiram nova inserção no mercado de trabalho, e, em particularidade de admissão, na cooperativa $C$ trabalhadores que estavam em processo de reintegração social por motivo de reclusão prisional, trabalhadores que dormiam em albergues, trabalhadores que estavam em recuperação de dependência química em casas de apoio da Prefeitura de São Paulo e trabalhadores encaminhados pela Casa de Apoio à Diversidade Sexual.

A distribuição dos catadores pelas atividades produtivas ocorria geralmente desta maneira: 1) a maior proporção encontrava-se na tarefa de triar, devido à necessidade de maior quantidade de mão de obra nesse setor. Essa tarefa demanda maior uso do tempo no processo produtivo e oferecia maior rentabilidade quando o pagamento era feito por produção individual e não por sistema de rateio mensal entre os cooperados; 2) na tarefa de coleta, o número de cooperados dependia da quantidade disponível de carros e da abrangência regional da coleta; 3) nas tarefas conhecidas como de apoio, executavam o recebimento de RS, o fornecimento dos RS para a mesa/esteira de triagem e o deslocamento de big-bags/barricas para a pesagem. Observouse que as catadoras (mulheres) da triagem pressionavam os trabalhadores do apoio para não deixarem cair seu papel de identificação dos big-bag/barrica e/ou fazer a pesagem e a anotação correta dos resíduos sólidos triados por elas; 4) a tarefa de prensagem tinha um número pequeno de cooperados pelo fato de ser um posto individual de trabalho e dependia do número de prensas que a cooperativa possuía. Observou-se nesse setor constante cobrança de produtividade, por ser esta a fase final de produção, e também pela 
necessidade de cuidado no manuseio do equipamento para não ocorrer algum tipo de avaria que demandasse conserto.

Os líderes de cada setor designavam a tarefa a ser executada pelo catador, fazendo a comunicação com líderes de outros setores, coordenador e cooperados. Qualquer sugestão, reclamação ou exigência que precisasse ser mencionada ou esclarecida em relação à execução da tarefa realizada, à conduta ou ao desempenho, era sempre feita pelo líder do setor ao catador, entre líderes de cada setor e entre líderes e coordenador.

A produtividade e o pagamento de cada catador se davam conforme a tarefa realizada e a organização administrativa estabelecida pela cooperativa, podendo ser realizado o pagamento de modo individual, por produção, ou de modo coletivo, por sistema de rateio. A tarefa de triar foi a que mais apresentou diferença na forma de pagamento nas quatro cooperativas, podendo ser por tipo de MR triado, pagamento individual, por hora ou por dia; pelos mesmos tipos de MRs triados por mais de uma catadora, como exemplo, se duas catadoras na esteira triavam um mesmo tipo de material, a produção das duas eram somadas e se pagava pela quantidade produzida em conjunto; ou se as catadoras estavam em lado opostos da esteira - o direito triava somente papel e o lado esquerdo somente plástico, independente dos subtipos desses MRs, o pagamento era calculado em conjunto de acordo com o lado da esteira e o pagamento por sistema de rateio entre todos os cooperados, distribuindo igualmente os ganhos. As demais funções eram renumeradas por hora ou por dia, estabelecendo-se um preço fixo por mês, calculado pelo total de materiais vendidos e pela quantidade de pessoas que trabalharam durante o mês todo. Foi relatado pelas pessoas que realizavam a administração e o pagamento que 
sempre ocorria questionamento quanto à quantidade vendida de RS e o valor recebido.

O principal objetivo das cooperativas era coletar maior quantidade de materiais recicláveis de qualidade, fazer sua comercialização diretamente com as empresas transformadoras e gerar renda para seus cooperados. O Quadro 3 descreve as principais características de cada cooperativa que compôs a amostra. O tempo de funcionamento, a quantidade de catadores, o tipo de coleta, os equipamentos, Equipamentos de Proteção Individual (EPIs), treinamentos e parcerias de instituições de saúde e privadas com as cooperativas pouco diferiam.

As instituições privadas que investiam em algum apoio ou benefício nas duas primeiras cooperativas (Natura e Ambev) as avaliavam periodicamente quanto à organização física, ao Estatuto, a aspectos judiciários e suas parcerias com organizações de saúde como as Unidades Básicas de Saúde (UBS) e os Centros de Referência de Assistência Social (CRAS). As parcerias de saúde tratavam de assuntos como vacinação, campanhas específicas, doenças sexualmente transmissíveis, entre outros. O CRAS fazia a assistência social. 
Quadro 3. Principais características das Cooperativas de Materiais Recicláveis da Região Metropolitana de São Paulo, 2015

\begin{tabular}{|c|c|c|c|c|}
\hline CARACTPISTCAS & COOPRATVAA & COOPBATVA B & COOPRATVAC & COCRBATVA D \\
\hline Ano de inicio & 2003 & 2004 & 2003 & 2000 \\
\hline $\mathrm{N}^{0}$ Catadores & $47(18,80 \%)$ & $63(25,20 \%)$ & $71(28,40 \%)$ & $69(27,60 \%)$ \\
\hline $\begin{array}{l}\text { Procedência dos } \\
\text { catadores }\end{array}$ & $\begin{array}{c}\text { Autônomo, do } \\
\text { lixão e procura } \\
\text { espontânea }\end{array}$ & Autônomo e indicação & $\begin{array}{l}\text { Indicação, } \\
\text { recrutamento } \\
\text { especifico }\end{array}$ & $\begin{array}{c}\text { Indicação, recrutamento } \\
\text { aviso portão }\end{array}$ \\
\hline Metragem galpão $\left(\mathrm{m}^{2}\right)$ & 3.500 & 5.000 & 4.000 & 5.000 \\
\hline Cobertura & Parcial & Parcial & Parcial & Parcial \\
\hline Ventilação & Natural & Natural & Natural & Natural \\
\hline Esgoto/água & Sim/Sabesp & Sim/Sabesp & Sim/Sabesp & Sim/Sabesp \\
\hline Pavimentação & Completa & Parcial & Completa & Parcial \\
\hline Cidade & São Paulo & São Paulo & São Paulo & Guarulhos \\
\hline Zoneamento & Oeste & Oeste & Centro & Oeste \\
\hline Filiação & MNCR & MNCR & MNCR & MNCR \\
\hline Credenciamento & Prefeitura SP & Prefeitura SP & Prefeitura SP & Prefeitura Guarulhos \\
\hline Tipo Coleta & $\begin{array}{l}\text { Porta a porta } \\
\text { recebimento } \\
\text { retirada e PEV }\end{array}$ & $\begin{array}{l}\text { Porta a porta } \\
\text { recebimento retirada }\end{array}$ & $\begin{array}{l}\text { Porta a porta } \\
\text { recebimento }\end{array}$ & $\begin{array}{l}\text { Porta a porta } \\
\text { recebimento PEV }\end{array}$ \\
\hline Equipamentos & \begin{tabular}{|l|} 
Mesa (1)* \\
Empilhadeira (1) \\
Carrinho mão (1) \\
Balança (1) \\
Prensa (1) \\
\end{tabular} & $\begin{array}{l}\text { Esteira (1) } \\
\text { Empilhadeira(1) } \\
\text { Carrinho mão(2) } \\
\text { Balança (2)Prensa (2) }\end{array}$ & \begin{tabular}{|l} 
Esteira (2) \\
Empilhadeira(1) \\
Carrinho mão(2) \\
Balança (2) \\
Prensa (3) \\
\end{tabular} & \begin{tabular}{|l} 
Esteira (2) \\
Empilhadeira(3) \\
Carrinhomão(5) \\
Balança (3) \\
Prensa (5) \\
\end{tabular} \\
\hline Distribuição de EPIs & Sim & $\operatorname{Sim}$ & Sim & $\operatorname{Sim}$ \\
\hline $\begin{array}{l}\text { Armazenamento } \\
\text { MR } \\
\end{array}$ & $\begin{array}{l}\text { Big-bag chão } \\
\text { Sacolas de alça } \\
\end{array}$ & Big-bag com suporte & $\begin{array}{l}\text { Big-bag } \\
\text { suspenso/chão }\end{array}$ & Barrica papelão \\
\hline Treinamentos & $\begin{array}{l}\text { Capacitação } \\
\text { reciclagem } \\
\text { Manuseio } \\
\text { equipamentos } \\
\quad \text { Sebrae** } \\
\text { Instituto GEA } \\
\text { ***- REEE }\end{array}$ & $\begin{array}{l}\text { Capacitação } \\
\text { reciclagem Manuseio } \\
\text { equipamentos } \\
\text { Sebrae } \\
\text { Instituto GEA -REEE } \\
\text { Formação } \\
\text { Cooperativismo } \\
\text { IPESA**** }\end{array}$ & $\begin{array}{l}\text { Capacitação } \\
\text { reciclagem Manuseio } \\
\text { equipamentos } \\
\text { Sebrae } \\
\text { Instituto GEA-REEE }\end{array}$ & $\begin{array}{l}\text { Capacitação reciclagem } \\
\text { Manuseio equipamentos } \\
\text { Sebrae } \\
\text { Instituto GEA-REEE } \\
\text { Primeiros socorros }\end{array}$ \\
\hline $\begin{array}{l}\text { Parceiros mais } \\
\text { importantes }\end{array}$ & Natura***** & Ambev******* & Pronatec******** & - \\
\hline Parceria Saúde & $\begin{array}{l}\text { Eventual } \\
\text { UBS Pq Lapa }\end{array}$ & $\begin{array}{l}\text { Permanente } \\
\text { CSE Barra Funda }\end{array}$ & $\begin{array}{l}\text { Permanente } \\
\text { CSE Barra Funda } \\
\text { CRAS }\end{array}$ & $\begin{array}{l}\text { Permanente UBS } \\
\text { Haroldo } \\
\text { CRAS }\end{array}$ \\
\hline
\end{tabular}

NOTAS: * refere à quantidade de equipamentos disponíveis

** Sebrae (Serviço Brasileiro de Apoio às Micro e Pequenas Empresas) - Curso Básico de Gestão Administrativa e Comercial.

***Instituto GEA - Projeto Eco-Eletro.

**** IPESA (Instituo de Projetos e Pesquisa Socioambientais) - Programa de Resíduos Sólidos.

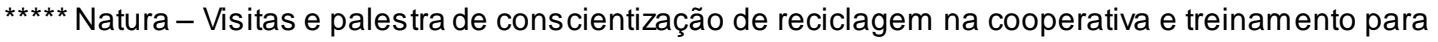
os catadores na captação e armazenamento dos frascos de vidro dos produtos Natura.

*****Ambev (Companhia de Bebidas das Américas) - Programa Recicla -Capacitação em desenvolvimento nas organizações de catadores e doação de equipamentos.

$\star \star \star \star \star \star \star$ Pronatec Catador - Qualificação profissional e tecnológica. 
Durante o levantamento de dados, observou-se que as instalações das cooperativas se encontravam deterioradas e abandonadas no que diz respeito ao espaço físico e equipamentos, demonstrando dificuldades enfrentadas por elas na manutenção e no processo produtivo. As instalações elétricas, pisos e os aspectos de edificação apresentavam irregularidades nas quatro cooperativas, como fios desencapados, soltos ou com emendas impróprias, pisos com altura irregular e quebrados, paredes quebradas com formatos irregulares para aumentar sua largura ou com uma nova abertura improvisada de passagem para veículos de trabalho ou MR. Os sanitários e os vestiários também se mostravam inadequados, em número reduzido e higiene deficiente, devido à insuficiência de colaboração dos próprios cooperados. Em uma das cooperativas foi relatado que ouso do banheiro só era aceito por pessoas do mesmo sexo, sendo proibido a transexuais entrar no banheiro feminino. Essa dificuldade de aceitação entre as catadoras estava gerando discórdia e constrangimento aos transexuais por serem obrigados a frequentar o banheiro masculino. Os bebedouros não eram suficientes, ficando em locais impróprios e com falta de higiene. Apenas uma cooperativa tinha um extintor de incêndio, que ficava em local sem visibilidade adequada. Não era realizada a manutenção preventiva de equipamentos, ferramentas e objetos de trabalho, só eram realizados reparos quando paravam de funcionar. Tais equipamentos, ferramentas e objetos eram usados mesmo em estado deteriorado, chegando a se tornar fator de risco para acidentes de trabalho.

Os EPIs eram fornecidos e distribuídos pelas prefeituras às cooperativas. Porém, os tipos de EPIs diferiam em cada cooperativa. Isso ocorria porque a distribuição não era feita no mesmo período, variando de uma 
para outra entre seis meses e um ano. Quanto às características dos EPIs, estes eram destinados à proteção em geral, mas não especificamente para as funções dos catadores. Os EPIs mais usados eram a roupa e a bota.

As cooperativas trabalhavam de acordo com suas condições específicas, fossem em relação ao processo de trabalho, em relação ao perfil dos catadores, em relação à produtividade mensal, em relação à comercialização dos diversos tipos de matérias e seu preço comercial no momento.

Os constantes percursos de coleta seletiva somados aos esforços dos catadores em diversificar ao máximo os resíduos sólidos no processo de triagem, a fim de agregar valor econômico ao seu trabalho, não eram suficientes, ou seja, somente essa ação não gerava ganho satisfatório.

Ainda uns dos grandes obstáculos a serem enfrentados é o grande montante de materiais rejeitados que chegam as cooperativas. A maior parte dos materiais chegavam em condições não reaproveitáveis para serem comercializados, indo para o rejeito. Estes não eram contabilizados em sua produção para pagamento, seja ele na forma individual ou coletiva. Portanto, em relação aos materiais que iam para o rejeito, o trabalho realizado por todos os catadores, independente da tarefa, não convertia em ganhos.

Além disso, a colaboração efetiva dos cidadãos e dos órgãos públicos no apoio ao programa de gestão integrada dos resíduos sólidos urbanos tende a seguir vagarosamente, conforme relato dos catadores. 


\subsection{Descrições das características sociodemográficas}

As características sociodemograficas estão descritas na Tabela 1.

Tabela 1 - Distribuição das variáveis sociodemográficas dos catadores do estudados, 2015

\begin{tabular}{|c|c|c|}
\hline & $\mathrm{n}$ & $\%$ \\
\hline \multicolumn{3}{|l|}{ Sexo } \\
\hline Feminino & 154 & 62 \\
\hline Masculino & 96 & 38 \\
\hline \multicolumn{3}{|l|}{ Idade } \\
\hline $19-29$ & 35 & 14 \\
\hline $30-40$ & 54 & 22 \\
\hline $41-59$ & 133 & 53 \\
\hline 60 ou + (idosos) & 28 & 11 \\
\hline \multicolumn{3}{|l|}{ Raça } \\
\hline Branco & 84 & 34 \\
\hline Negros e pardos & 166 & 66 \\
\hline \multicolumn{3}{|l|}{ Procedência } \\
\hline Sudeste e Sul & 129 & 52 \\
\hline $\mathrm{N}, \mathrm{NO}$ e $\mathrm{CO}^{*}$ & 121 & 48 \\
\hline \multicolumn{3}{|l|}{ Escolaridade } \\
\hline Não alfabetizado & 21 & 8 \\
\hline Alfabetizado/1a $-4^{a}$ & 87 & 35 \\
\hline $5^{a}-8^{a}$ & 84 & 34 \\
\hline Médio/superior** & 58 & 23 \\
\hline
\end{tabular}

Nota: * $\mathrm{N}=$ Norte, $\mathrm{NO}=$ Nordeste e $\mathrm{CO}=$ Centro-Oeste

**= Apenas uma catadora cursava o ensino superior

A média de idade foi de 43,5 anos. Devido à pequena quantidade de catadores que declara naturalidade nas Regiões Sul, Norte e Centro-Oeste houve a necessidade de se fazer agrupamentos de categorias quanto a essas variáveis. Observou-se que 35\% declararam até quatro anos de estudos. A 
catadora que cursava o ensino superior relatou que havia ganhado bolsa integral e cursava Direito.

\subsection{Descrição das condições de trabalho}

Os catadores realizavam a maior parte das tarefas manualmente, desenvolvendo seu processo produtivo por meio da vivência e das precárias condições de trabalho. A história laboral e informações sobre as atividades profissionais encontram-se na Tabela 2.

Tabela 2: Variáveis da história laboral e das informações sobre as atividades no trabalho, 2015

\begin{tabular}{|c|c|c|}
\hline & $\mathrm{n}$ & $\%$ \\
\hline \multicolumn{3}{|c|}{ História laboral } \\
\hline \multicolumn{3}{|c|}{ Pagamento ao INSS } \\
\hline Sim & 239 & 96 \\
\hline Não & 11 & 4 \\
\hline \multicolumn{3}{|c|}{ Tempo de trabalho } \\
\hline 1 mês - 1 ano & 73 & 29 \\
\hline $2-3$ anos & 54 & 22 \\
\hline $4-6$ anos & 48 & 19 \\
\hline $7-10$ anos & 43 & 17 \\
\hline $11-14$ anos & 23 & 9 \\
\hline 15 - 19 anos & 5 & 2 \\
\hline $20-23$ anos & 4 & 2 \\
\hline \multicolumn{3}{|c|}{ Ocupação anterior a de catador } \\
\hline Sim & 144 & 58 \\
\hline Não & 106 & 42 \\
\hline \multicolumn{3}{|c|}{ Acidente de trabalho } \\
\hline Sim & 86 & 34 \\
\hline Não & 164 & 66 \\
\hline \multicolumn{3}{|c|}{ Postura de trabalho } \\
\hline Sentada & 17 & 7 \\
\hline Em pé & 220 & 88 \\
\hline Alternada & 13 & 5 \\
\hline \multicolumn{3}{|c|}{ Realização esforço físco } \\
\hline $\operatorname{Sim}$ & 227 & 91 \\
\hline Não & 23 & 9 \\
\hline
\end{tabular}


A maioria dos catadores contribuía para o Instituo Nacional do Seguro Social (INSS) devido às cooperativas descontar em folha de pagamento, os que não contribuíam já estavam aposentados.

O tempo total de trabalho como catador na história laboral variava de um mês a 23 anos. Observou-se maior proporção de tempo de trabalho até 06 anos (70\%). A partir de sete anos de trabalho o número de profissionais diminuía consideravelmente.

As outras ocupações anteriormente desempenhadas foram em serviço de limpeza e como ajudante geral. Poucas ocupações necessitavam de alguma qualificação para atuar, com curso técnico.

Quanto aos acidentes de trabalho, 86 (34\%) dos catadores auto declararam ter sofrido algum tipo de acidente. Porém, ressalte-se que 164 (66\%) não consideravam cortes e perfurações nas mãos/pés como acidente de trabalho, achando o ocorrido natural, sendo parte da rotina de trabalho. Eles haviam se acostumado com esses acontecimentos.

Quanto à região do corpo em que ocorriam acidentes, estes se apresentavam nas mãos e punhos (60 ou 70\%) e nos membros inferiores/coluna/cabeça/olhos (26ou 30\%). Verificou-se, portanto, que os membros superiores (MMSS) eram os mais acometidos em relação aos membros inferiores (MMII) e outras partes do corpo.

Nos MMSS havia relato de perfurações com caco de vidro e metais. Nos MMII ocorreram os mesmos tipos de perfurações além de lesões de entorse de tornozelo, a coluna vertebral era afetada quando ocorria queda da própria altura. Foi relatado que a maioria das quedas ocorria devido a obstáculos por diversos objetos ao redor, o apoio de pé no caminhão de coleta e o tipo de bota 
(com bico de aço) que usavam, este tipo de bota não permite a percepção da sensibilidade ao toque, o catador não conseguia perceber quando o seu pé enroscava na alça da big-bag ou algum outro local que seu pé encostava.

Os catadores relataram que o tipo de postura assumida para a execução da tarefa, seja ela na posição sentada ou em pé, visava à facilidade do fluxo dos MRs e à sua produção, não podendo ser realizada em outra posição, especialmente nas tarefas de coleta, do recebimento, do fornecimento de MR, da triagem e da prensa.

A posição alternada encontrava-se em funções de apoio, coordenação, liderança, trabalho com vidros e REEE. A posição sentada era comum em trabalhadores que exerciam as tarefas de administração, entre os motoristas e na função de armazenamento quando esta era realizada exclusivamente em mini carregadeiras (empilhadeiras).

Para a percepção do esforço físico intenso foi o mais perceptível entre os catadores, ficando o esforço moderado e leve em proporções semelhantes, porém menores.

Quanto às condições de trabalho e o relato das percepções dos catadores sobre ruído, iluminação e temperatura estão listadas na Tabela 3.

Tabela 3. Percepção das condições de trabalho, 2015

\begin{tabular}{lccccccc}
\hline & \multicolumn{3}{c}{ Condições de trabalho } & & \\
& Ruído & \multicolumn{1}{l}{ lluminação } & Temperatura & \\
\hline Percepção & $\mathrm{N}$ & $\%$ & $\mathrm{~N}$ & $\%$ & $\mathrm{~N}$ & $\%$ \\
Ruim/Regular & 223 & 89 & 137 & 55 & 218 & 87 \\
Bom/Boa/Ótima(0) & 27 & 11 & 113 & 45 & 32 & 13 \\
\hline TOTAL & & & & & & 250 & 100
\end{tabular}


Observou-se que o ruído era a condição física que mais causava desconforto aos catadores. A localidade de três cooperativas era próxima a vias de trafego intenso de veículos, porém o som das prensas parecia superar a do tráfego conforme os relatos dos catadores. Em apenas uma cooperativa a proximidade com o aeroporto mostrou influenciar os resultados, e as prensas eram localizadas fora do galpão de triagem.

Os relatos para percepção da iluminação ruim/regular e boa, foram semelhantes. Os galpões eram abertos nas laterais em toda extensão. Na frente com abertura total, praticamente sem porta; o principal tipo de iluminação era a natural. Os dias estavam ensolarados quando ocorreu a coleta de dados.

No dia da coleta de dados a temperatura estava elevada. Porém, houve menção de que, na época do inverno, havia queda de temperatura, provocando desconforto térmico também. Os catadores referiam que, dependendo da época do ano, sofriam de qualquer maneira com a temperatura. As entrevistas foram realizadas no final da estação de inverno, durante toda a primavera e início do verão.

\subsection{Descrições da organização e fatores psicossociais do trabalho}

Os catadores ao fazer relatos sobre o modo de organização do seu trabalho demonstraram entendimento de como desempenham sua função. A Tabela 4 mostra uma síntese dessa percepção. 
Tabela 4. Percepção das variáveis de organização do trabalho e a satisfação em pertencer à categoria profissional nos 250 catadores, 2015

\begin{tabular}{|c|c|c|c|c|}
\hline \multicolumn{5}{|l|}{ Organização e fatores psicosociais } \\
\hline & \multicolumn{3}{|c|}{ Percepção } & \\
\hline & Não & $\%$ & Sim & $\%$ \\
\hline Repetitividade & 33 & 13 & 217 & 87 \\
\hline Rodízio & 181 & 72 & 69 & 28 \\
\hline Pausa & 32 & 13 & 218 & 87 \\
\hline Monotonia & 35 & 14 & 215 & 86 \\
\hline Verificação de produção & 92 & 37 & 158 & 63 \\
\hline Satisfação no trabalho & 128 & 51 & 122 & 49 \\
\hline TOTAL & & & 250 & 100 \\
\hline
\end{tabular}

A repetitividade, a pausa e a monotonia foram às condições de organização mais percebidas entre os catadores. Os horários do café da manhã e da tarde, e o almoço foram considerados pausas no trabalho pelos catadores. Três pausas ao dia relatadas por 218 (87\%) catadores. Os catadores que relatavam não ter pausas para descanso faziam as tarefas de coleta de rua, apoio e administrativa.

A contagem de produção foi relatada por 158 (63\%) dos catadores. O fechamento da produtividade da cooperativa ocorria no final de cada mês. $\mathrm{O}$ engajamento dos cooperados na última semana do mês era perceptível em todas as cooperativas. Procurava-se superar ou pelo menos manter a produtividade do mês anterior. Quando ocorria troca de função ou apenas de posição (de um local para outro), no caso da tarefa de triar, elas achavam a mudança complicada, por terem que se adaptar a uma nova organização de 
trabalho e temerem diminuir sua produção. As catadoras relatavam insatisfação quando ocorria esse tipo de mudança. A adaptação a essa troca exigia novo aprendizado cognitivo.

A satisfação em ser catador ou não foi similar, por um lado é interessante essa percepção para autovalorização profissional. A maioria dos relatos sobre a insatisfação em ser catador deve-se por não possuírem vínculo de trabalho que Ihes proporcione os mesmos direitos da consolidação das leis de trabalho.

\subsection{Descrição da dor/desconforto osteomuscular nos 12 meses que antecederam o estudo em relação ao processo de trabalho}

Os catadores que trabalhavam nas cooperativas de triagem procuravam seguir uma rotina mensal como qualquer outro trabalhador formal, com o propósito de manter uma organização de trabalho tinham: oito horas diárias de trabalho, horas extras e regras a cumprir estabelecidas. Os catadores estudados, por cumprirem diariamente suas funções em cooperativa, provavelmente poderiam apresentar maior susceptibilidade a sintomas osteomusculares decorrentes do processo de trabalho em relação aos catadores autônomos, por estes não necessitar seguir jornadas e regras.

Dos catadores entrevistados 163 (65\%) perceberam sentir dor/desconforto nos últimos doze meses por motivo da sua profissão (Tabela 5). 


\section{Tabela 5. Distribuição de dor/desconforto osteomusculares, 2015}

\begin{tabular}{|c|c|c|}
\hline \multicolumn{3}{|c|}{ Dor/Desconforto nos últimos 12 meses } \\
\hline & $\mathrm{N}^{0}$ & $\%$ \\
\hline Não & 87 & 35 \\
\hline Sim & 163 & 65 \\
\hline$\overline{\text { TOTAL }}$ & 250 & 100 \\
\hline
\end{tabular}

Dos 163 catadores (65\%) que tiveram a percepção de dor/desconforto, $44(27 \%)$ deles referiram sintomatologia dolorosa em mais de uma região corporal, enquanto que 119 (73\%) apenas em uma região corporal, 82 (50\%) relataram a dor na região da coluna, 74 (45\%) nos membros superiores e 51 (31\%) nos membros inferiores.

As tarefas que se destacaram mais críticas em relação aos riscos biomecanicos nas cooperativas pesquisadas foram as de coletar, abastecimento da mesa/esteira de triagem, de triar, prensar, transportar manualmente os RS e a de motorista da empilhadeira quando observadas e analisadas conforme o "Protocolo de Complexidades Diferenciadas de DORT" desenvolvido pelo Ministério da Saúde e do Trabalho, o qual descreve que as predisposições dos sintomas osteomusculares, podem ter relação com a postura, com predomínio ereta; com os tipos de movimentos, sendo predominante o agachamento e a rotação de tronco; com à repetitividade do movimento, com o modo de pegar, carregar, empurrar e levantar peso, e ao esforço físico desempenhado(Ministério da Saúde,2012).

Os riscos ergonômicos que envolvem fatores biomecânicos foram observados: (1) na postura em pé por longo período nas tarefas de coletar, 
abastecer a mesa/esteira, de triar, transportar manualmente os RS e de prensar; (2) na execução de movimentos de carregar, empurrar e arrastar peso nas tarefas de transportar manualmente e de prensar os RS; (3) na execução de movimentos de pegar e lançar sacos na tarefa de descarregar os RS dos veículos; (4) na execução dos movimentos de inclinação e torção de tronco combinados nas tarefas de coletar, descarregar os RS dos veículos,abastecer a mesa/esteira e de triar; (5) na execução do movimento de flexão do ombro acima de 90 graus na tarefa de prensar, ao acionar os botões; (6) na postura sentada estática com flexão de coluna, flexão em 90 graus dos ombros e rotação da coluna cervical,e, exigência de posturas inadequadas de membros inferiores para o acionamento dos pedais na tarefa de dirigir a empilhadeira;e os risco que envolvem fatores organizacionais foram: (1) execução de movimentos repetitivos e monotonia no conteúdo da atividade nas tarefas de abastecer a mesa/esteira, de triar e de prensar; (2) controle de produção quando esta é contada, ocorrendo nas tarefas de coletar porta a porta, triar e prensar; (3) exigência de demandas visuais nas tarefas de triar e de dirigir a empilhadeira. Esses riscos biomecanicos consequentemente podem levar a riscos de acidentes por associarem aos meios de produção o qual foram encontrados nas cooperativas, arranjos físicos e armazenamentos de RS inadequados, maquinários sem proteção e ferramentas/objetos defasados e EPIs inapropriados. Assim como fatores psicossociais que estão relacionados ao contexto individual de cada catador e dependem da maneira de como eles enfrentam as situações vivenciadas dentro da cooperativa. 


\subsection{Análise Univariada}

5.6.1. Descrição da dor/desconforto osteomuscular nos últimos 12 meses que antecedem ao estudo segundo meios de produção das cooperativas, características sociodemográficas, situação social e história laboral

As relações entre dor/desconforto osteomusculares e os meios de produção da cooperativa, características sociodemográficas, contribuição para o INSS e história laboral relatadas pelos catadores apresentam-se na Tabela 6.

A dor/desconforto nos 12 meses que antecederam a coleta de dados foi mais frequente na categoria sexo feminino embora essa diferença não seja significativa e na raça negra/parda. Também não foram observadas diferenças estatisticamente significantes em relação à categoria escolaridade e contribuição ao INSS. Os catadores que reportaram ter tido outra ocupação profissional anterior a de catador apresentaram diferença estatisticamente significante $(p=0.007)$, sendo que esses indivíduos apresentaram quase 3 vezes mais dor/desconforto do que aqueles que não tiveram outra ocupação a anterior de catador. 
Tabela 6. Dor/desconforto nos últimos 12 meses, segundo características sociodemográficas, meios de produção da cooperativa, situação social e história laboral, 2015

\begin{tabular}{|c|c|c|c|c|}
\hline VARIÁVEL & DOR/DESCONFORTO (N/\%) & OR *** & 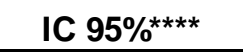 & P-valor ${ }^{\star \star \star \star *}$ \\
\hline $\begin{array}{l}\text { Cooperativa } \\
\text { (condições e os } \\
\text { meios de } \\
\text { trabalho) }\end{array}$ & $\begin{array}{l}A=39(83 \%) \\
B=45(71 \%) \\
C=50(70 \%) \\
D=29(42 \%)\end{array}$ & $\begin{array}{l}6,66 \\
3,45 \\
3,33\end{array}$ & $\begin{array}{c}2,78-16,67 \\
1,67-7,14 \\
1,64-6,67\end{array}$ & 0,001 \\
\hline Sexo & $\begin{array}{l}\text { Feminino= } 105(68 \%) \\
\text { Masculino= } 58(61 \%)\end{array}$ & 1,37 & $0,80-2,32$ & 0,249 \\
\hline Raça & $\begin{array}{l}\text { Branca }=49(58 \%) \\
\text { Negra/parda= } 114(69 \%)\end{array}$ & 1,56 & $0,90-2,69$ & 0,107 \\
\hline Estado & $\begin{array}{l}\text { NE/N/CO* }=82(63 \%) \\
\text { SU/S = } 81(68 \%)\end{array}$ & 1,24 & $0,73-2,10$ & 0,409 \\
\hline Escolaridade & $\begin{array}{l}\text { Não Alfabetizado= } 12(57 \%) \\
\text { Alfabetizado }-4^{\mathrm{a}}=58(67 \%) \\
5^{\mathrm{a}}-8^{\mathrm{a}} \text { série }=58(69 \%) \\
2^{\circ} \mathrm{Grau}-\text { Superior }=35(60 \%)\end{array}$ & $\begin{array}{l}1,50 \\
1,67 \\
1,14\end{array}$ & $\begin{array}{l}0,56-3,96 \\
0,62-4,45 \\
0,41-3,13\end{array}$ & 0,612 \\
\hline INSS** & $\begin{array}{l}\mathrm{NÃO}=6(54 \%) \\
\mathrm{SIM}=157(66 \%)\end{array}$ & 1,59 & $0,47-5,38$ & 0,456 \\
\hline $\begin{array}{l}\text { Outra ocupação } \\
\text { (anterior a de } \\
\text { catador) }\end{array}$ & $\begin{array}{l}\mathrm{NA} O=19(46 \%) \\
\mathrm{SIM}=144(69 \%)\end{array}$ & 2,56 & $1,29-5,06$ & 0,007 \\
\hline
\end{tabular}

A diferença de prevalência de dor/desconforto entre as cooperativas foi estatisticamente significante $(p=0,001)$, indicando existir diferença entre as cooperativas com respeito aos meios de produção de trabalho. Na cooperativa A os equipamentos como a esteira, o carrinho de mão, a empilhadeira e a prensa mecanizada estavam em manutenção, todas as tarefas eram executadas manualmente; enquanto que nas outras cooperativas todos os equipamentos estavam em funcionamento, ressalta-se que a cooperativa $D$ 
tinha uma maior quantidade de equipamentos em funcionamento em relação às demais, e possuía dois turnos de trabalho. Todas as variáveis com nível de significância menor do que 0,20 foram incluídas na análise múltipla.

\subsubsection{Descrição da dorldesconforto osteomuscular nos últimos 12 meses que antecedem ao estudo segundo condições de trabalho}

As relações existentes entre a ocorrência de acidente de trabalho, postura adotada, esforço físico realizado e condições de trabalho percebidas pelos catadores e a presença de dor/desconforto musculoesqueléticos apresentam-se na Tabela 7 .

A dor/desconforto foi cerca de 3 vezes mais frequente entre aqueles que relataram a ocorrência de acidente de trabalho $(p=0,001)$. Os catadores que trabalham na posição ereta e alternada e os que tiveram percepção de realizar esforço físico durante a tarefa foram os que mais apresentaram relato de dor, embora essas associações não tenham sido estatisticamente significantes. Quanto a categoria das condições físicas do trabalho (ruído, iluminação e temperatura) não foram estatisticamente significantes (ruído com $p=0,273$, iluminação com $p=0,476$ e temperatura com $p=0,463$ ) mesmo que o rúdo e a temperatura apresentassem maior proporção de respostas em percepção de regular/ruim. 
Tabela 7. Dor/desconforto nos últimos 12 meses, segundo características das condições de trabalho, 2015

\begin{tabular}{|c|c|c|c|c|}
\hline VARIÁVEL & $\begin{array}{l}\text { DOR/DESCONFORTO } \\
\mathrm{N}(\%)\end{array}$ & OR * & IC 95\%** & $\begin{array}{l}\text { P- } \\
\text { valor*** }\end{array}$ \\
\hline $\begin{array}{l}\text { Acidente de } \\
\text { Trabalho }\end{array}$ & $\begin{array}{l}\text { Não= } 93(57 \%) \\
\text { Sim }=70(81 \%)\end{array}$ & 3,34 & $1,78-6,23$ & 0,001 \\
\hline Postura & $\begin{array}{l}\text { Sentada= } 10(59 \%) \\
\text { Em pé= } 145(66 \%) \\
\text { Alternada= } 8(61 \%)\end{array}$ & $\begin{array}{l}1,35 \\
1,20\end{array}$ & $\begin{array}{l}0,49-3,69 \\
0,38-3,84\end{array}$ & $\begin{array}{l}0,778 \\
0,931\end{array}$ \\
\hline Esforço físico & $\begin{array}{l}\text { Não= } 15(65 \%) \\
\text { Sim= } 148(65 \%)\end{array}$ & 0,99 & $0,40-2,45$ & 0,999 \\
\hline Ruído & $\begin{array}{l}\text { Ruim/Regular=148 (55\%) } \\
\text { Bom= } 15(66 \%)\end{array}$ & 1,57 & $0,70-3,54$ & 0,273 \\
\hline Iluminação & $\begin{array}{l}\text { Ruim/Regular= } 92(67 \%) \\
\text { Boa/Ótima= } 71(63 \%)\end{array}$ & 1,22 & $0,72-2,04$ & 0,476 \\
\hline Temperatura & $\begin{array}{l}\text { Ruim/Regular= } 144(66 \%) \\
\text { Boa/Ótima= } 19(59 \%)\end{array}$ & 1,33 & $0,62-2,86$ & 0,463 \\
\hline
\end{tabular}

NOTA: * OD= Razão de chances

** IC= Intervalo de confiança

*** p-valor= probabilidade de significância

Aqueles que relataram ter tido acidente de trabalho apresentaram 3,34 vezes mais queixas de dor/desconforto, sugerindo uma associação estatisticamente significante entre dor/desconforto e acidente de trabalho $(p=0,001)$.

Os catadores que realizam a tarefa na postura em pé apresentaram 1,35 vezes mais queixas de dor/desconforto, embora não seja estatisticamente significante $(p=0,077)$. Dos catadores que referiram o ruído ruim/regular apresentou 1,57 vezes mais queixas de dor/desconforto, enquanto que a 
percepção da temperatura regular/ruim apresentou 1,33 vezes mais queixas de dor/desconforto $(p=0,463)$.

Não houve diferença na prevalência de dor/desconforto entre os catadores que reportaram ou não realizar esforço físico na sua tarefa $(p=0,999)$, ressalta-se que seria necessário estudar a descrição dos catadores que realizam esforço físico e não referiram dor quanto a suas características sociais e história laboral.

\subsubsection{Descrição da dor/desconforto osteomuscular nos últimos 12 meses que antecedem ao estudo segundo organização do trabalho e o fator psicossocial}

A presença de dor/desconforto musculoesqueléticos e as relações existentes entre a organização e a satisfação no trabalho apresentam-se na Tabela 8.

Os que relataram a percepção do trabalho monótono apresentaram 1,72 vezes mais queixas de dor/desconforto, enquanto os que relataram repetitividade 1,81 vezes. As duas variáveis podem ser incluídas na análise múltipla, seu nível de significância são menores do que 0,20 (monotonia com $p=0,150$ e repetitividade com $p=0,161)$. 
Tabela 8. Dor/desconforto nos 12 meses, segundo características

\begin{tabular}{|c|c|c|c|c|}
\hline VARIAVEL & $\begin{array}{c}\text { DOR/DESCONFORTO } \\
(\mathrm{N} / \%)\end{array}$ & OR * & IC $95 \%^{* *}$ & P-valor \\
\hline Monotonia & $\begin{array}{l}\text { Não= } 19(67 \%) \\
\text { Sim }=144(54 \%)\end{array}$ & 1,72 & $0,83-3,57$ & 0,150 \\
\hline Repetitividade & $\begin{array}{l}\text { Não }=25(76 \%) \\
\text { Sim }=138(64 \%)\end{array}$ & 1,81 & $0,77-4,17$ & 0,161 \\
\hline Rodízio & $\begin{array}{l}\text { Não = } 11(65 \%) \\
\text { Sim= } 152(67 \%)\end{array}$ & 1,09 & $0,60-1,96$ & 0,763 \\
\hline Pausa & $\begin{array}{l}\text { Não= } 19(59 \%) \\
\text { Sim= } 144(66 \%)\end{array}$ & 1,33 & $0,62-2,84$ & 0,463 \\
\hline $\begin{array}{l}\text { Verificação de } \\
\text { produção }\end{array}$ & $\begin{array}{l}\text { Não= } 59(62 \%) \\
\text { Sim= } 104(67 \%)\end{array}$ & 1,25 & $0,73-2,14$ & 0,413 \\
\hline Satisfação & $\begin{array}{l}\text { Não= } 42(60 \%) \\
\text { Sim }=121(67 \%)\end{array}$ & 1,36 & $0,77-2,41$ & 0,285 \\
\hline
\end{tabular}

NOTA: * OD= Razão de chances

** IC= Intervalo de confiança

*** p-valor= probabilidade de significância

Os catadores que não tem rodízio de função apresentaram 1,09 vezes mais queixas de dor/desconforto, os que tem função em que é necessário contar a produção 1,25 vezes mais queixas de dor/desconforto e os que não tem satisfação no trabalho 1,36 vezes mais queixas de dor/desconforto, embora essas variáveis não sejam estatisticamente significantes. 


\subsection{Modelo de Análise Múltipla}

As variáveis selecionadas como explicativas de dor/desconforto para a análise múltipla foram às seguintes: cooperativa $(p<0,001)$, raça $(p=0,107)$, outra ocupação $(p=0,007)$, acidente de trabalho $(p<0,001)$, monotonia $(p=0,150)$ e repetitividade $(p=0,161)$.

Após o ajuste da regressão logística (stepwise) restaram as variáveis processo produtivo das Cooperativas, outra ocupação e acidente de trabalho como possíveis explicações para dor/desconforto relacionadas ao trabalho nos últimos 12 meses que antecederam o estudo.

Tabela 9. Variáveis associadas à dor/desconforto osteomusculares nos catadores das cooperativas estudadas, 2015

\begin{tabular}{|c|c|c|c|c|}
\hline VARIÁVEL & CATEGORIA & $\mathrm{OR}^{\star}$ & IC 95\%** & $P-$ valor $^{\star \star \star}$ \\
\hline $\begin{array}{l}\text { Cooperativa } \\
\text { (condições e os } \\
\text { meios de trabalho) }\end{array}$ & $A, B, C, D$ & $\begin{array}{l}A=5,05 \\
B=2,94 \\
C=2,65 \\
D\end{array}$ & $\begin{array}{l}2,05-12,72 \\
1,39-6,25 \\
1,28-5,74\end{array}$ & 0,001 \\
\hline $\begin{array}{l}\text { Outra ocupação } \\
\text { (anterior a de } \\
\text { catador) }\end{array}$ & $\begin{array}{l}\text { Não } \\
\text { Sim }\end{array}$ & 2,13 & $1,02-4,44$ & 0,043 \\
\hline Acidente de trabalho & $\begin{array}{l}\text { Não } \\
\text { Sim }\end{array}$ & 2,78 & $1,44-5,35$ & 0,001 \\
\hline
\end{tabular}

Houve diferença estatisticamente significante $(p<0,001)$ entre a chance de desenvolver dor/desconforto nos últimos 12 meses que antecedem ao estudo nos catadores que trabalham nas cooperativas B e C, na cooperativa B apresentaram 2,94 vezes mais queixas e na cooperativa C 2,65 vezes. Houve diferença estatisticamente significante $(p<0,001)$ nos catadores que trabalham 
na cooperativa D quando comparada às demais, podendo-se considerar como fator de proteção trabalhar na cooperativa denominada D, que se encontrou provida de maior quantidade de equipamentos e catadores. Portanto a chance de ter dor/desconforto nos trabalhadores da cooperativa A é de 5,05 maior em relação às outras, sendo esta a mais desprovida no processo produtivo devido aos catadores realizarem todas as tarefas manualmente. A categoria ter outra ocupação anterior a de catador $(p=0,043)$ apresentou 2,13 vezes mais chance de ter dor/desconforto osteomuscular e acidente de trabalho $(p<0,001)$ apresentou 2,78 vezes mais de ter dor/desconforto; apresentando risco estatisticamente significante quanto ao relato de dor/desconforto osteomusculares. 


\section{DISCUSSÃO}





\section{Discussão}

O perfil demográfico dos catadores analisado nesse estudo foi semelhante ao encontrado em levantamento do IPEA (2013), exceto com relação ao gênero, onde os autores encontraram predomínio do sexo masculino (68,9\%), o que pode ser explicado pelo fato de que nesta amostra os dados foram coletados no censo demográfico de 2010, ano o qual a maioria das cooperativas estava dando início à formalização devido à aprovação da Lei 12.305/2010 da Política Nacional de Resíduos Sólidos (PNRS).

O perfil de escolaridade levantado na amostra resultou semelhante aos estudos realizados com catadores por Medeiros e Macedo (2006), Porto et al. (2004), Bosi (2008), Jesus et al. (2010) e IPEA (2013).

Quanto à contribuição previdenciária foi encontrada uma proporção de 96\% de contribuintes para o INSS, dado que diverge do levantamento do PNAD (15,4\%) (apud IPEA, 2013). O desconto do INSS é caráter obrigatório para todos os catadores que atuam dentro das cooperativas, e realizado diretamente sobre a folha de pagamento, o que pode justificar a alta proporção encontrada de contribuintes.

Em relação à história laboral chama atenção a estabilidade na ocupação de catador, onde $70 \%$ dos entrevistados declaram possuir pelo menos seis anos de trabalho na cooperativa. Outro dado relevante refere-se a que metade dos entrevistados declara nunca exerceu outra ocupação anteriormente a de catador. Observou-se que todos os catadores da amostra, que declararam alguma ocupação anteriormente, a exerceram em serviços gerais; e, 
ressaltaram nas entrevistas, sobre o dispêndio de esforço físico para tal, sendo este dado compatível com estudos anteriores (Porto et al., 2004; Bosi, 2008).

Os catadores não diferem dos trabalhadores em geral quando observadas as ocorrências de acidentes de trabalho, sendo a mão o local de maior proporção de acidentes (Anuário estatístico de INSS, planilha de CID 10, região sudeste, 2013). Ressalta-se que os acidentes ocorridos foram devido aos objetos perfurocortantes encontrados no meio dos resíduos sólidos, esta condição é devido à falta de colaboração por parte da sociedade em separar de forma correta seus resíduos.

Coluna, ombro e joelho foram às regiões do corpo mais citadas como sede de sintomas de dor/desconforto, no que se assemelha ao encontrado entre os trabalhadores em geral (Anuário estatístico de INSS, planilha de CID 10, região sudeste, 2013). A dor é referida em maior proporção na coluna e no ombro, sendo este resultado compatível com os estudos realizado pelo National Institute for Occupational Safety and Health -NIOSH (1997), em trabalhadores de indústria de bens de consumo, bens de produção e do comércio nos Estados Unidos, Alemanha, Suécia, Rússia e Japão.

Estudos com amostra composta por catadores autônomos, e/ou cooperativados e/ou coletores de lixo de rede pública (gari) também confirmam a presença de dor/desconforto osteomuscular em decorrência das condições de trabalho, sendo as regiões anatômicas mais afetadas a coluna lombar, o ombro e o joelho, reforçando os achados desse estudo. Vale notar que tais resultados foram encontrados tanto em estudos cujo desenho envolveu questionários específicos para explorar de forma autorreferida a ocorrência de dor/desconforto osteomuscular (Silva et al, 2007; Alencar et al, 2009; 
Alexandrino et al, 2009; Jesus et al, 2010; Castilhos Junior et al, 2013), ou por estudos que abordaram a ocorrência de incômodos de forma geral, e a dor osteomuscular foi a mais reportada pelos catadores (Anjo e Ferreira, 2000; Porto et al, 2004; Gutberlet e Baeder, 2008; Almeida et al, 2009; Tavares et al, 2009; Costa e Tambellini, 2009; Bazo et al, 2011; Abreu e Rodrigues, 2011).

Os fatores de riscos ocupacionais mais relatados neste estudo foram esforço físico, postura inadequada, repetitividade, monotonia, local de trabalho ruidoso e temperatura desconfortável, corroborando os achados de outros autores (Velloso et al., 1997; Calderoni, 1999; Cavalcante e Franco, 2007; Albizu et al., 2008 ${ }^{10}$; Covre et al., 2009 ${ }^{11}$; Virgem, 2010; Batista et al., 2013; Hoefel et al., 2013; Cavalcante et al., 2014; Parra et al., 2015). A maioria dos catadores que compuseram esses estudos reconhece as condições desfavoráveis e os riscos que envolvem a profissão.

Resultados semelhantes quanto à presença de dor/desconforto também foram observados em estudos com trabalhadores informais em geral (Bernardino e Andrade, 2015), que presumivelmente possuem características semelhantes de inserção ocupacional, classe social, rentabilidade, escolaridade e vulnerabilidade.

\footnotetext{
${ }^{10}$ Albizu EJ, Lima CA, Piaskowy P. Segurança e saúde no trabalho de catador de material reciclável. In: XX Seminário Sul-Brasileiro da ANAMT, Curitiba, PR, 2008. Anais (26 a 29 de novembro de 2008) apud Cavalcante LPS, Silva MCVG, Alencar LD, Vasconcelos SCS, Assis DS. Impactos Socioambientais decorrentes da profissão catador de material reciclável: estudo de caso. Polêmica [online]. 2012;11(4):661-676. [citado 1 mar. 2017]. Disponível em:http://www.e-publicacoes.uerj.br/index.php/polemica/article/view/4334/3132

${ }^{11}$ Covre CBSV, Zulian MAR, FranciscoNPF. Identificação dos riscos ergonômicos nas etapas de triagem de materiais recicláveis da urbam em São José dos Campos-SP. In: XIII Encontro Latino Americano de Iniciação Científica - IX Pós Graduação - III Iniciação Cient Junior, 2009. [citado 21 fev. 2017]. Disponível em: http://www.inicepg.univap.br/cd/INIC_2009/anais/arquivos/0397_1469_01.pdf
} 
Este tipo de estudo é inédito ao selecionar uma amostra dentro da RMSP, exclusivamente de cooperativas de triagem. Ressalta-se que o questionário utilizado teve validação internacional (Kuorinka, l.; Forcier, L. (Ed.). Work-related musculoskeletal disorders (WMSDs): a reference book for prevention. Great Britain: Taylor \& Francis, 1995) e brasileira (Pinheiro et al, 2002); tendo sido utilizado em estudo de prevalência de LER/DORT por Mussi (2005).

Os dados do questionário foram coletados pela mesma pesquisadora em todo o período realizado e todos os catadores presentes no dia da coleta aceitaram participar da pesquisa. O questionário foi revisto ao término de cada entrevista com o objetivo de certificar se todas as informações foram capturadas. A pesquisadora buscou uma maior aproximação com os catadores realizando a coleta de dados junto ao catador em seu posto de trabalho, no momento em que ele executava sua tarefa, iniciando com um diálogo a respeito do seu cotidiano, para introduzir a entrevista dirigida com o questionário.

Uma limitação do estudo diz respeito à amostragem de conveniência adotada. O contato inicial com as cooperativas foi realizado por meio do Movimento Nacional dos Catadores de Recicláveis, que indicou aquelas consideradas mais receptivas à pesquisa. Após visitas a várias cooperativas, percebeu-se que muitas delas possuíam características semelhantes, sendo que as quatro cooperativas estudadas refletem as condições gerais das cooperativas da RMSP. 


\section{CONCLUSÃO}





\section{Conclusão}

A Política Nacional de Resíduos Sólidos reúne princípios, objetivos, instrumentos, diretrizes, metas e ações como resposta aos problemas que se tornaram públicos, os resíduos sólidos. Contempla como um dos principais trabalhadores na gestão integrada, os catadores. Estes desenvolvem um papel fundamental na gestão dos resíduos sólidos urbanos, desde a coleta, o armazenamento e a preservação do meio ambiente. Compreende sua importância nos serviços públicos de limpeza urbana e manejo dos resíduos sólidos, entretanto, as condições de trabalho no que diz respeito a uma renumeração equitativa, de segurança, de proteção e perspectivas de desenvolvimento profissional não tem sido implementada no contexto prático desta política.

Embora se reconheça que os catadores estejam expostos a riscos biológicos, químicos, físicos e biomecânicos, ainda não se têm pesquisas mensurando a sua intensidade e freqüência na execução de uma determinada tarefa ao longo da jornada de trabalho, que são aspectos relevantes para a caracterização do risco.

Este estudo encontrou alta prevalência de dor/desconforto osteomuscular relacionado às condições de trabalho e as características ocupacionais. Condições de trabalho estão associadas à organização, ao modo de produção do catador e às condições disponíveis de produtividade das cooperativas, seja em quantidade de equipamentos, ferramentas, objetos e mobiliário e nas condições de funcionamento destes. 
Nas cooperativas, a prática de rotinas impede que os catadores tenham um tempo hábil para a preparação de um planejamento das condições mais adequadas de trabalho, com resultados a posteriori; compreendeu-se que eles costumeiramente executam suas tarefas diárias com um único propósito "o de acumular" grande quantidade de materiais recicláveis, o que influencia no aumento do seu ganho e não demonstram preocupação com as condições laborais e a maneira que eles procedem para atingir seus objetivos.

A importância de distinguir no seu posto de trabalho quais as condições desfavoráveis à saúde pareceu ser percebida por todos catadores da amostra, no entanto, pequenas e imediatas mudanças que poderiam ser implementadas pelos próprios catadores para prevenir morbidades, que podem vir a afetar o sistema musculoesquelético não foram relevantes neste estudo. Preferindo permanecer com seus postos de trabalho e o modo operatório, com a alegação de estarem acostumados e que quaisquer mudanças poderiam afetar $\mathrm{o}$ desempenho deles.

Quanto à história laboral, ao que antecede a ocupação profissional de catador, as atividades anteriormente desempenhadas pelos catadores também apresentaram a necessidade de realizar algum esforço físico, geralmente desempenhando atividades de maior intensidade braçal.

Já a ocorrência de acidente de trabalho pode abranger várias situações, como as condições físicas e organizacionais, os meios e o modo de uma determinada ação do catador. Segundo relato dos catadores que sofreram acidente, a dor poderia ter influenciado na sua concentração no momento em que realiza a tarefa, predispondo-os a ocorrência de acidente de trabalho. 
A dor mesmo tratando de caráter subjetivo mostrou associação com o processo de trabalho, a história laboral e a ocorrência de acidente de trabalho.

Os catadores de cooperativas de reciclagem não diferem quanto à sintomatologia do sistema osteomuscular em relação a outras ocupações de semelhante qualificação, como também não se distinguem da população geral de trabalhadores quanto à ocorrência de dor musculoesquelética. Não obstante, há necessidade de mais estudos em cooperativas de reciclagem, voltados a avaliar a morbidade osteomuscular referida decorrente dos fatores envolvidos no processo de trabalho.

Dado o reconhecimento da sua ocupação e a importância do seu papel na gestão dos resíduos nas cidades brasileiras, considero necessário o apoio de órgãos públicos responsáveis pela saúde do trabalhador com o propósito de desenvolver ações de educação, assistência, promoção e vigilância em âmbito nacional e suas respectivas localidades, levando em consideração as habilidades e competências dos catadores. Desta forma os catadores serão enquadrados nas Políticas Públicas de Trabalho do Sistema Único de Saúde e poderão ser contemplados no reconhecimento dos diferentes agentes de riscos ocupacionais dentro de uma cooperativa de reciclagem e gerar indicadores de saúde dos catadores. Uma vez que concretizado tais medidas coloca-os em condições de trabalho que delimita o que pode ser tolerável a saúde humana. 

8. ANEXOS 

ANEXO I

MORBIDADE REFERIDA PARA DISTÚRBIOS OSTEOMUSCULARES RELACIONADOS AO TRABALHO (DORT)

I- IDENTIFICAÇÃO

NÚMERO DO QUESTIONÁRIO INDIVIDUAL:

NÚMERO DO QUESTIONÁRIO DA COOPERATIVA A QUE PERTENCE:

NOME COMPLETO:

NOME DA MÃE:

E-MAIL:

TELEFONE:

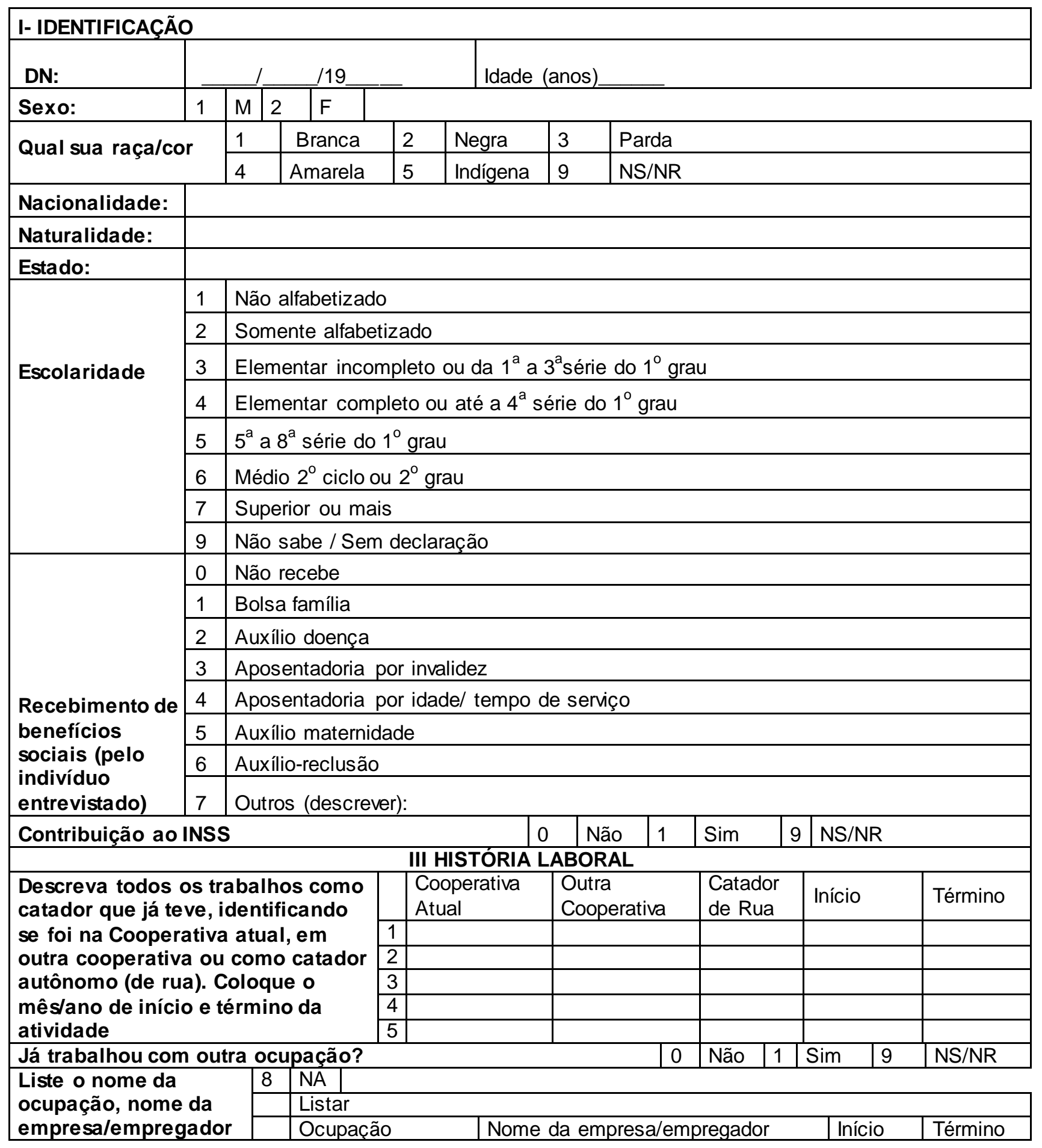




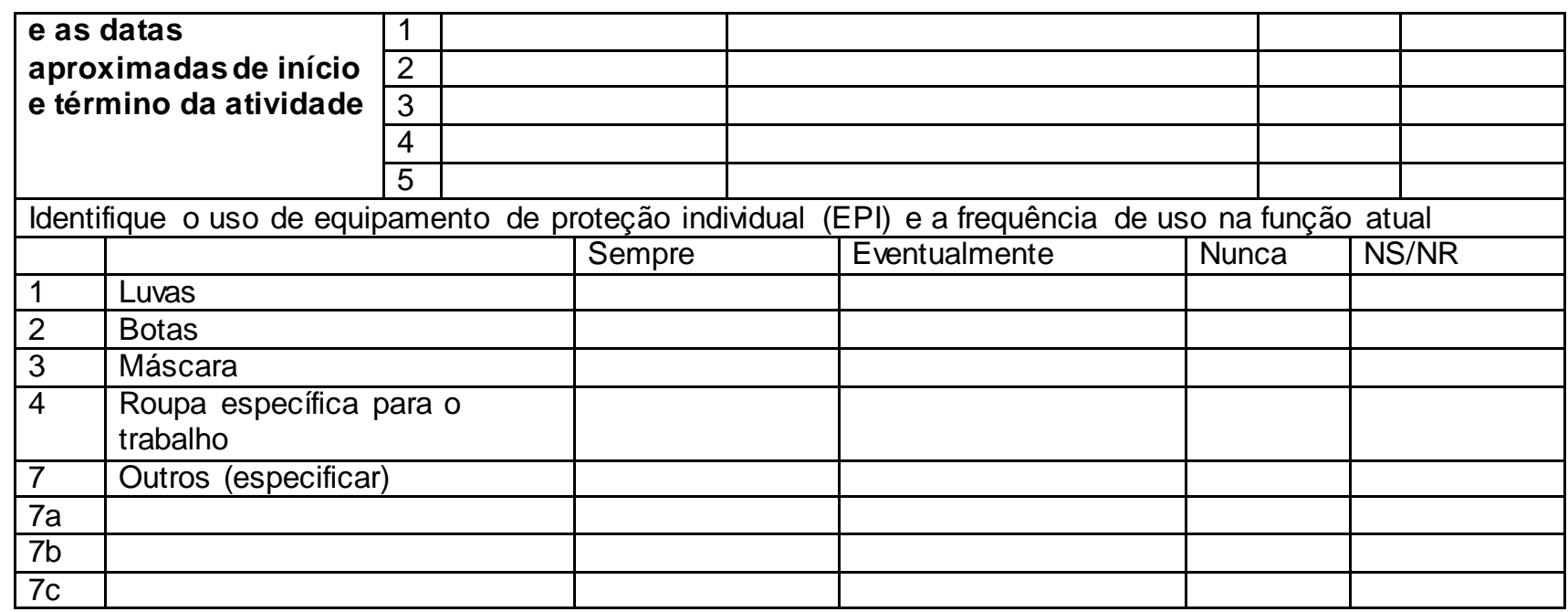

\section{A- INFORMAÇÕES SOBRE AS ATIVIDADES PROFISSIONAIS}

A1. Em qual setor você trabalha na Cooperativa?

1- Coleta 2- recebimento de resíduos sólidos 3-alimentação da esteira/mesa 4- triagem 5transporte dos bag/barricas 6- prensa 7- balança 8-vidros 9- RE EE 10- armazenamento dos fardos 11- administração 12- cozinha/refeitório e limpeza 13- outros, qual?

A2. Qual sua função nesta Cooperativa?

A3. Você já teve algum acidente de trabalho nesta Cooperativa?

0- Não

1- Sim, foi nesta tarefa 2- Sim, não foi nesta tarefa

A4. Se você respondeu sim na pergunta anterior, qual foi a parte do corpo atingida:(pode responder mais de um item)

1- dedos da mão 2- mão 3- braço 4- ombro 5- cabeça 6- rosto 7-costas 8- peito 9- bacia 10- coluna 11- joelho 12- tornozelo 13- dedos do pé 14- pé 15- olhos

\section{B- INFORMAÇÕES SOBRE AS CONDIÇÕES DE TRABALHO}

B1. A sua postura mais frequente de trabalho é:

1- Sentada 2- Em pé 3- Alternada

B2. Você utiliza instrumentos (pinça, alicate, martelo, tesoura, vassoura, garfo de cabo longo etc.) para o trabalho?

0- Não

1- Sim, qual?

B3. Você realiza esforços físicos em sua tarefa?

0- Não

1- Sim, leve 2- Sim, moderado 3- Sim, pesado

B4. Seu local de trabalho é ruidoso?

0- Não

1- Sim, baixo 2- Sim, médio 3- Sim, alto

B5. A iluminação do ambiente é:

1- Péssima 2-Ruim 3- Regular 4- Boa 5- Ótima

B6. A temperatura do ambiente é:

1- Péssima 2- Ruim 3- Regular 4- Boa 5- Ótima

C- ORGANIZAÇÃO DO TRABALHOI FATORES PSICOSOCIAIS 
C1. Teve treinamento para exercer a função?
0- Não
1- Sim

C2. O seu trabalho exige concentração/atenção?

1- nunca 2-raramente 3- às vezes 4 - com frequência 5- sempre

C3. O seu trabalho é monótono?

1- nunca 2-raramente 3 - às vezes 4 - com frequência 5 - sempre

C4. As tarefas que realiza são repetitivas?

0- Não 1- Sim

C5. É necessário prestar muita atenção para não errar?

0- Não 1- Sim

C6. Tem rodízio de atividade?

0 - Não

1- Sim, diário 2- Sim, semanal 3- Sim, mensal

C7. Você tem controle sobre seu ritmo de trabalho?

1- nunca 2- raramente 3- às vezes 4- com frequência 5- sempre

C8. Você trabalha em ritmo acima do seu limite?

1- nunca 2- raramente 3- às vezes 4-com frequência 5- sempre

C9. Tem pausas ou micro pausas programadas durante as atividades (podendo ser horário de lanche ou pausa estabelecida)?

0- Não

1- Sim, 1 vez ao dia 2- Sim, 2 vezes ao dia 3- Sim, 3 vezes ao dia 4- Sim, mais de 3 vezes ao dia

C10. Sua produção é contada?

0- Não

1- Sim, individual 2- Sim, coletiva

C11. Você trabalha em um ambiente muito competitivo?

1- nunca 2- raramente 3- às vezes 4-com frequência 5- sempre

C12. O tipo de trabalho que você faz provoca desgaste emocional?

1- nunca 2- raramente 3 - às vezes 4 - com frequência 5- sempre

C13. Sente satisfação e realização pessoal no trabalho?

1- nunca 2- raramente 3 - às vezes 4 - com frequência 5- sempre

C14. O que você acha que poderia melhorar no seu processo de trabalho?

C15. Alguma coisa no trabalho the incomoda?

0- Não 1- Sim, o quê? 


\section{D- INFORMAÇÕES SOBRE O TRABALHO DOMÉSTICO}

D1. Quando você está em casa é sua responsabilidade:

\begin{tabular}{|r|r|l|l|l|l|l|}
\hline & & $\begin{array}{l}\text { Não } \\
=0\end{array}$ & $\begin{array}{l}\text { Sim, } \\
\text { a menor } \\
\text { parte= 1 }\end{array}$ & $\begin{array}{l}\text { Sim, dividido } \\
\text { igualmente=2 }\end{array}$ & $\begin{array}{l}\text { Sim, a } \\
\text { maior } \\
\text { parte= 3 }\end{array}$ & $\begin{array}{l}\text { Sim, } \\
\text { Integralmente } \\
=4\end{array}$ \\
\hline A & Cuidar das crianças & & & & & \\
\hline B & Cuidar da limpeza & & & & & \\
\hline C & Lavar roupas & & & & & \\
\hline D & Passar roupas & & & & & \\
\hline
\end{tabular}

D2. Tem alguém que mora com você e necessita de cuidados constantes?

\begin{tabular}{|r|r|r|r|r|r|r|}
\hline & $\begin{array}{r}\text { Pessoa Portadora } \\
\text { de } \\
\text { Deficiência }\end{array}$ & $\begin{array}{r}\text { Não } \\
=0\end{array}$ & $\begin{array}{r}\text { Sim, } \\
\text { a menor } \\
\text { parte=1 }\end{array}$ & $\begin{array}{r}\text { Sim, dividido } \\
\text { igualmente=2 }\end{array}$ & $\begin{array}{r}\text { Sim, a } \\
\text { maior } \\
\text { parte= 3 }\end{array}$ & $\begin{array}{r}\text { Integralmente } \\
=4\end{array}$ \\
\hline A & Visual & & & & & \\
\hline B & Auditiva & & & & & \\
\hline D & Física & & & & & \\
\hline E & Mista (incluir física) & & & & & \\
\hline
\end{tabular}

D3. Em relação ao esforço físico, como você classificaria suas atividades domésticas?

1- Não faz tarefas domésticas

2- Faz tarefas domésticas, sendo leve

3- Faz tarefas domésticas, sendo moderada

4- Faz tarefas domésticas, sendo pesada 


\section{E- INFORMAÇÕES SOBRE MORBIDADE REFERIDA}

E1. No último ano você tem apresentado algum tipo de dor ou desconforto em alguma região do corpo, que você acha que está relacionado com o trabalho, tendo sintomas durante e/ou após as atividades?

0- Não, encerre o questionário.

$1-$

Sim, responda as questões abaixo de acordo com o local e o tipo de desconforto

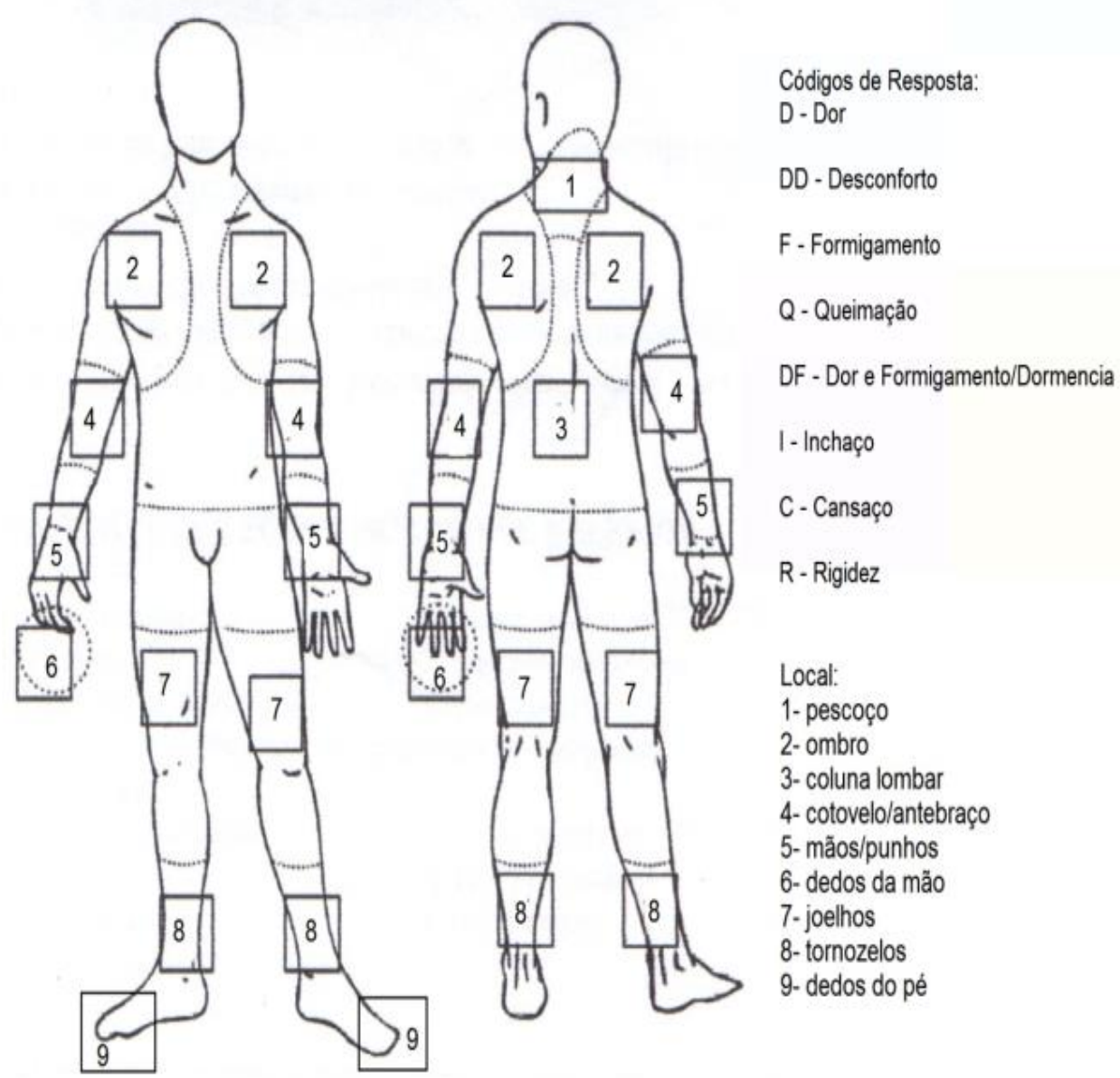




\begin{tabular}{|c|c|c|c|}
\hline & Pescoço (1): & Ombro (2): & Coluna (3): \\
\hline $\begin{array}{l}\text { E2- Qual lado } \\
\text { incomoda? }\end{array}$ & $\begin{array}{l}\text { 1- Esquerdo } \\
\text { 2- Direito } \\
\text { 3- Ambos }\end{array}$ & $\begin{array}{l}\text { 1- Esquerdo } \\
\text { 2- Direito } \\
\text { 3- Ambos }\end{array}$ & $\begin{array}{l}\text { 1- Esquerdo } \\
\text { 2- Direito } \\
\text { 3- Ambos }\end{array}$ \\
\hline $\begin{array}{l}\text { E3- Há quanto tempo } \\
\text { se iniciou o } \\
\text { problema? }\end{array}$ & _ & __ meses; & _ \\
\hline $\begin{array}{l}\text { E4- Qual a duração } \\
\text { aproximada do } \\
\text { problema? }\end{array}$ & $\begin{array}{l}\text { 1- até } 1 \text { hora } \\
\text { 2- de } 1 \text { a } 24 \text { horas } \\
\text { 3- mais de } 24 \text { horas } \\
\text { até } 1 \text { semana } \\
\text { 4- mais de } 1 \text { semana } \\
\text { a } 1 \text { mês } \\
\text { 5- mais de } 1 \text { mês a } 6 \\
\text { meses } \\
\text { 6- mais de } 6 \text { meses } \\
\text { 9- não se lembra }\end{array}$ & $\begin{array}{l}\text { 1- até } 1 \text { hora } \\
\text { 2- de } 1 \text { a } 24 \text { horas } \\
\text { 3- mais de } 24 \text { horas } \\
\text { até } 1 \text { semana } \\
\text { 4- mais de } 1 \text { semana } \\
\text { a } 1 \text { mês } \\
5 \text { - mais de } 1 \text { mês a } 6 \\
\text { meses } \\
\text { 6- mais de } 6 \text { meses } \\
\text { 9- não se lembra }\end{array}$ & $\begin{array}{l}\text { 1- até } 1 \text { hora } \\
\text { 2- de } 1 \text { a } 24 \text { horas } \\
\text { 3- mais de } 24 \text { horas } \\
\text { até } 1 \text { semana } \\
\text { 4- mais de } 1 \text { semana } \\
\text { a } 1 \text { mês } \\
\text { 5- mais de } 1 \text { mês a } 6 \\
\text { meses } \\
\text { 6- mais de } 6 \text { meses } \\
\text { 9- não se lembra }\end{array}$ \\
\hline $\begin{array}{l}\text { E5- Com que } \\
\text { frequência você } \\
\text { apresenta o } \\
\text { problema? }\end{array}$ & $\begin{array}{l}\text { 1- Constantemente } \\
\text { 2- } 1 \text { vez por semana } \\
\text { 3- } 1 \text { vez por mês } \\
\text { 4- raramente }\end{array}$ & $\begin{array}{l}\text { 1- Constantemente } \\
\text { 2- } 1 \text { vez por semana } \\
\text { 3- } 1 \text { vez por mês } \\
\text { 4- raramente }\end{array}$ & $\begin{array}{l}\text { 1- Constantemente } \\
\text { 2- } 1 \text { vez por semana } \\
\text { 3- } 1 \text { vez por mês } \\
\text { 4- raramente }\end{array}$ \\
\hline $\begin{array}{l}\text { E6- Apresentou o } \\
\text { problema nos últimos } \\
7 \text { dias? }\end{array}$ & $\begin{array}{l}\text { 0- Não } \\
\text { 1- Sim }\end{array}$ & $\begin{array}{l}\text { 0- Não } \\
\text { 1- Sim }\end{array}$ & $\begin{array}{l}\text { 0- Não } \\
\text { 1- Sim }\end{array}$ \\
\hline $\begin{array}{l}\text { E7- Em uma escala } \\
\text { de } 0=\text { sem } \\
\text { desconforto } \\
1=\text { desconforto leve } \\
2=\text { desconforto } \\
\text { moderado } \\
3=\text { desconforto forte } \\
4=\text { desconforto } \\
\text { intenso suportável } \\
5=\text { desconforto } \\
\text { intenso insuportável }\end{array}$ & $\begin{array}{l}\text { 1- Esquerdo } \\
\text { 2- Direito } \\
\text { 3- Ambos }\end{array}$ & $\begin{array}{l}\text { 1- Esquerdo } \\
\text { 2- Direito } \\
\text { 3- Ambos }\end{array}$ & $\begin{array}{l}\text { 1- Esquerdo } \\
\text { 2- Direito } \\
\text { 3- Ambos }\end{array}$ \\
\hline $\begin{array}{l}\text { E8- Dias perdidos de } \\
\text { trabalho devido ao } \\
\text { problema no último } \\
\text { ano? }\end{array}$ & & & \\
\hline $\begin{array}{l}\text { E9- Recebeu algum } \\
\text { tratamento médico } \\
\text { para o problema? }\end{array}$ & $\begin{array}{l}\text { 0- Não } \\
\text { 1- Sim }\end{array}$ & $\begin{array}{l}\text { 0- Não } \\
\text { 1- Sim }\end{array}$ & $\begin{array}{l}\text { 0- Não } \\
\text { 1- Sim }\end{array}$ \\
\hline $\begin{array}{l}\text { E10- você mudou de } \\
\text { função por causa do } \\
\text { problema? }\end{array}$ & $\begin{array}{l}\text { 0- Não } \\
\text { 1- Sim }\end{array}$ & $\begin{array}{l}\text { 0- Não } \\
\text { 1- Sim }\end{array}$ & $\begin{array}{l}\text { 0- Não } \\
\text { 1- Sim }\end{array}$ \\
\hline
\end{tabular}

E11. O que você acha que piora seu problema?

E12. O que você acha que causou o problema?

E13. O que você acha que melhora os sintomas? 


\begin{tabular}{|c|c|c|c|}
\hline & Cotovelo/antebraço(4): & Mão/punho (5): & Dedos (6): \\
\hline $\begin{array}{l}\text { E2- Qual lado } \\
\text { incomoda? }\end{array}$ & $\begin{array}{l}\text { 1- Esquerdo } \\
\text { 2- Direito } \\
\text { 3- Ambos }\end{array}$ & $\begin{array}{l}\text { 1- Esquerdo } \\
\text { 2- Direito } \\
\text { 3- Ambos }\end{array}$ & $\begin{array}{l}\text { 1- Esquerdo } \\
\text { 2- Direito } \\
\text { 3- Ambos }\end{array}$ \\
\hline $\begin{array}{l}\text { E3- Há quanto tempo } \\
\text { se iniciou o } \\
\text { problema? }\end{array}$ & meses; & meses; & meses; \\
\hline $\begin{array}{l}\text { E4- Qual a duração } \\
\text { aproximada do } \\
\text { problema? }\end{array}$ & $\begin{array}{l}\text { 1- até } 1 \text { hora } \\
\text { 2- de } 1 \text { a } 24 \text { horas } \\
\text { 3- mais de } 24 \text { horas } \\
\text { até } 1 \text { semana } \\
\text { 4- mais de } 1 \text { semana a } \\
1 \text { mês } \\
\text { 5- mais de } 1 \text { mês a } 6 \\
\text { meses } \\
\text { 6- mais de } 6 \text { meses } \\
\text { 9- não se lembra }\end{array}$ & $\begin{array}{l}\text { 1- até } 1 \text { hora } \\
\text { 2- de } 1 \text { a } 24 \text { horas } \\
\text { 3- mais de } 24 \text { horas } \\
\text { até } 1 \text { semana } \\
\text { 4- mais de } 1 \text { semana } \\
\text { a } 1 \text { mês } \\
\text { 5- mais de } 1 \text { mês a } 6 \\
\text { meses } \\
\text { 6- mais de } 6 \text { meses } \\
\text { 9- não se lembra }\end{array}$ & $\begin{array}{l}\text { 1- até } 1 \text { hora } \\
\text { 2- de } 1 \text { a } 24 \text { horas } \\
\text { 3- mais de } 24 \text { horas } \\
\text { até } 1 \text { semana } \\
\text { 4- mais de } 1 \text { semana } \\
\text { a } 1 \text { mês } \\
\text { 5- mais de } 1 \text { mês a } 6 \\
\text { meses } \\
\text { 6- mais de } 6 \text { meses } \\
\text { 9- não se lembra }\end{array}$ \\
\hline $\begin{array}{l}\text { E5- Com que } \\
\text { frequência você } \\
\text { apresenta o } \\
\text { problema? }\end{array}$ & $\begin{array}{l}\text { 1- Constantemente } \\
\text { 2- } 1 \text { vez por semana } \\
\text { 3- } 1 \text { vez por mês } \\
\text { 4- raramente }\end{array}$ & $\begin{array}{l}\text { 1- Constantemente } \\
\text { 2- } 1 \text { vez por semana } \\
\text { 3- } 1 \text { vez por mês } \\
\text { 4- raramente }\end{array}$ & $\begin{array}{l}\text { 1- Constantemente } \\
\text { 2- } 1 \text { vez por semana } \\
\text { 3- } 1 \text { vez por mês } \\
\text { 4- raramente }\end{array}$ \\
\hline $\begin{array}{l}\text { E6- Apresentou o } \\
\text { problema nos últimos } \\
7 \text { dias? }\end{array}$ & $\begin{array}{l}\text { 0- Não } \\
\text { 1- Sim }\end{array}$ & $\begin{array}{l}\text { 0- Não } \\
\text { 1- Sim }\end{array}$ & $\begin{array}{l}\text { 0- Não } \\
\text { 1- Sim }\end{array}$ \\
\hline $\begin{array}{l}\text { E7- Em uma escala } \\
\text { de } 0=\text { sem } \\
\text { desconforto } \\
1=\text { desconforto leve } \\
2=\text { desconforto } \\
\text { moderado } \\
3=\text { desconforto forte } \\
4=\text { desconforto } \\
\text { intenso suportável } \\
5=\text { desconforto } \\
\text { intenso insuportável }\end{array}$ & $\begin{array}{l}\text { 1- Esquerdo } \\
\text { 2- Direito } \\
\text { 3- Ambos }\end{array}$ & $\begin{array}{l}\text { 1- Esquerdo } \\
\text { 2- Direito } \\
\text { 3- Ambos }\end{array}$ & $\begin{array}{l}\text { 1- Esquerdo } \\
\text { 2- Direito } \\
\text { 3- Ambos }\end{array}$ \\
\hline \multicolumn{4}{|l|}{$\begin{array}{l}\text { E8- Dias perdidos de } \\
\text { trabalho devido ao } \\
\text { problema no último } \\
\text { ano? }\end{array}$} \\
\hline $\begin{array}{l}\text { E9- Recebeu algum } \\
\text { tratamento médico } \\
\text { para o problema? }\end{array}$ & $\begin{array}{l}\text { 0- Não } \\
\text { 1- Sim }\end{array}$ & $\begin{array}{l}\text { 0- Não } \\
\text { 1- Sim }\end{array}$ & $\begin{array}{l}\text { 0- Não } \\
\text { 1- Sim }\end{array}$ \\
\hline $\begin{array}{l}\text { E10- você mudou de } \\
\text { função por causa do } \\
\text { problema? }\end{array}$ & $\begin{array}{l}\text { 0- Não } \\
\text { 1- Sim }\end{array}$ & $\begin{array}{l}\text { 0- Não } \\
\text { 1- Sim }\end{array}$ & $\begin{array}{l}\text { 0- Não } \\
\text { 1- Sim }\end{array}$ \\
\hline
\end{tabular}

E11. O que você acha que piora seu problema?

E12. O que você acha que causou o problema?

E13. O que você acha que melhora os sintomas? 


\begin{tabular}{|c|c|c|c|}
\hline & Perna (7): & Tornozelo (8): & Pé (9): \\
\hline $\begin{array}{l}\text { E2- Qual lado } \\
\text { incomoda? }\end{array}$ & $\begin{array}{l}\text { 1- Esquerdo } \\
\text { 2- Direito } \\
\text { 3- Ambos }\end{array}$ & $\begin{array}{l}\text { 1- Esquerdo } \\
\text { 2- Direito } \\
\text { 3- Ambos }\end{array}$ & $\begin{array}{l}\text { 1- Esquerdo } \\
\text { 2- Direito } \\
3 \text { - Ambos }\end{array}$ \\
\hline $\begin{array}{l}\text { E3- Há quanto tempo } \\
\text { se iniciou o } \\
\text { problema? }\end{array}$ & _ meses; & __ meses; & __ meses; \\
\hline $\begin{array}{l}\text { E4- Qual a duração } \\
\text { aproximada do } \\
\text { problema? }\end{array}$ & $\begin{array}{l}\text { 1- até } 1 \text { hora } \\
\text { 2- de } 1 \text { a } 24 \text { horas } \\
\text { 3- mais de } 24 \text { horas } \\
\text { até } 1 \text { semana } \\
\text { 4- mais de } 1 \text { semana } \\
\text { a } 1 \text { mês } \\
\text { 5- mais de } 1 \text { mês a } 6 \\
\text { meses } \\
\text { 6- mais de } 6 \text { meses } \\
\text { 9- não se lembra }\end{array}$ & $\begin{array}{l}\text { 1- até } 1 \text { hora } \\
\text { 2- de } 1 \text { a } 24 \text { horas } \\
\text { 3- mais de } 24 \text { horas } \\
\text { até } 1 \text { semana } \\
\text { 4- mais de } 1 \text { semana } \\
\text { a } 1 \text { mês } \\
\text { 5- mais de } 1 \text { mês a } 6 \\
\text { meses } \\
\text { 6- mais de } 6 \text { meses } \\
\text { 9- não se lembra }\end{array}$ & $\begin{array}{l}\text { 1- até } 1 \text { hora } \\
\text { 2- de } 1 \text { a } 24 \text { horas } \\
\text { 3- mais de } 24 \text { horas } \\
\text { até } 1 \text { semana } \\
\text { 4- mais de } 1 \text { semana } \\
\text { a } 1 \text { mês } \\
\text { 5- mais de } 1 \text { mês a } 6 \\
\text { meses } \\
\text { 6- mais de } 6 \text { meses } \\
\text { 9- não se lembra }\end{array}$ \\
\hline $\begin{array}{l}\text { E5- Com que } \\
\text { frequência você } \\
\text { apresenta o } \\
\text { problema? }\end{array}$ & $\begin{array}{l}\text { 1- Constantemente } \\
\text { 2- } 1 \text { vez por semana } \\
\text { 3- } 1 \text { vez por mês } \\
\text { 4- raramente }\end{array}$ & $\begin{array}{l}\text { 1- Constantemente } \\
\text { 2- } 1 \text { vez por semana } \\
\text { 3- } 1 \text { vez por mês } \\
\text { 4- raramente } \\
\end{array}$ & $\begin{array}{l}\text { 1- Constantemente } \\
\text { 2- } 1 \text { vez por semana } \\
\text { 3- } 1 \text { vez por mês } \\
\text { 4- raramente }\end{array}$ \\
\hline $\begin{array}{l}\text { E6- Apresentou o } \\
\text { problema nos últimos } \\
7 \text { dias? }\end{array}$ & $\begin{array}{l}\text { 0- Não } \\
\text { 1- Sim }\end{array}$ & $\begin{array}{l}\text { 0- Não } \\
\text { 1- Sim }\end{array}$ & $\begin{array}{l}\text { 0- Não } \\
\text { 1- Sim }\end{array}$ \\
\hline $\begin{array}{l}\text { E7- Em uma escala } \\
\text { de } 0=\text { sem } \\
\text { desconforto } \\
1=\text { desconforto leve } \\
2=\text { desconforto } \\
\text { moderado } \\
3=\text { desconforto forte } \\
4=\text { desconforto } \\
\text { intenso suportável } \\
5=\text { desconforto } \\
\text { intenso insuportável }\end{array}$ & $\begin{array}{l}\text { 1- Esquerdo } \\
\text { 2- Direito } \\
\text { 3- Ambos }\end{array}$ & $\begin{array}{l}\text { 1- Esquerdo } \\
\text { 2- Direito } \\
\text { 3- Ambos }\end{array}$ & $\begin{array}{l}\text { 1- Esquerdo } \\
\text { 2- Direito } \\
\text { 3- Ambos }\end{array}$ \\
\hline \multicolumn{4}{|l|}{$\begin{array}{l}\text { E8- Dias perdidos de } \\
\text { trabalho devido ao } \\
\text { problema no último } \\
\text { ano? }\end{array}$} \\
\hline $\begin{array}{l}\text { E9- Recebeu algum } \\
\text { tratamento médico } \\
\text { para o problema? }\end{array}$ & $\begin{array}{l}\text { 0- Não } \\
\text { 1- Sim }\end{array}$ & $\begin{array}{l}\text { 0- Não } \\
\text { 1- Sim }\end{array}$ & $\begin{array}{l}\text { 0- Não } \\
\text { 1- Sim }\end{array}$ \\
\hline $\begin{array}{l}\text { E10- você mudou de } \\
\text { função por causa do } \\
\text { problema? }\end{array}$ & $\begin{array}{l}\text { 0- Não } \\
\text { 1- Sim }\end{array}$ & $\begin{array}{l}\text { 0- Não } \\
\text { 1- Sim }\end{array}$ & $\begin{array}{l}\text { 0- Não } \\
\text { 1- Sim }\end{array}$ \\
\hline
\end{tabular}

E11. O que você acha que piora seu problema?

E12. O que você acha que causou o problema?

E13. O que você acha que melhora os sintomas? 
ANEXO II

TERMO DE CONSENTIMENTO LIVRE E ESCLARECIDO

\section{DADOS DE IDENTIFICAÇÃO DO SUJEITO DA PESQUISA}

1. NOME:

DOCUMENTO DE IDENTIDADE No: SEXO: $\quad M \square F \square$ DATA NASCIMENTO: .l. $.1 \ldots \ldots . . . .$. ENDEREÇO: No........APTO: BAIRRO: .CIDADE CEP:

TELEFONE: DDD ...)

\section{DADOS SOBRE A PESQUISA}

1. TÍTULO DO PROTOCOLO DE PESQUISA: Condições de Trabalho e Morbidade Referida para Distúrbios Osteomusculares em Catadores de Materiais Recicláveis

PESQUISADOR: Nelson da Cruz Gouveia

CARGO/FUNÇÃO: Docente INSCRIÇÃO CONSELHO REGIONAL

UNIDADE DO FMUSP: Departamento de Medicina Preventiva

2. AVALIAÇÃO DO RISCO DA PESQUISA:

RISCO MÍNIMO $\quad$ X RISCO MÉDIO $\square$ RISCO BAIXO $\square \quad$ RISCO MAIOR $\square$

3.DURAÇÃO DA PESQUISA: 3 anos

Professor Dr. Nelson da Cruz Gouveia

Departamento de Medicina Preventiva da Faculdade de Medicina da Universidade de São Paulo Telefone (11) 3061-7075

Comitê de Ética em Pesquisa (01246-000) Av. Dr. Arnaldo, 455 - Instituto Oscar Freire - $1^{\circ}$ andar - tel: 3061- 8004 - E-mail: cep.fmusp@hcnet.usp.br

\section{FACULdADE de MEdicina dA UNIVERSIDAde de SÃo PAULO}

Gostaríamos de convidá-lo (a) a participar da presente pesquisa que tem o objetivo de avaliar os riscos à saúde que possam estar relacionados com o trabalho desenvolvido nas Cooperativas de Materiais Recicláveis. Sua participação ocorrerá da seguinte forma:

1- Ao aceitar participar da pesquisa você ficará com um Termo de Consentimento Livre e Esclarecido (TCLE). 
2- As perguntas iniciais serão sobre seus dados pessoais e questões relativas ao seu processo de trabalho.

O tempo médio de aplicação do questionário é de 60 minutos.

Este projeto de pesquisa envolve riscos mínimos, o (a) $\mathrm{Sr}$ (a) tem direito a indenização em caso de danos decorrente a sua participação nesta pesquisa.

O investigador principal é o Prof. Dr. Nelson da Cruz Gouveia, pode ser encontrado no Departamento de Medicina Preventiva da Faculdade de Medicina da Universidade de São Paulo, telefone (11) 3061 -7075. Caso você tenha alguma consideração ou dúvida sobre a ética da pesquisa, você pode procurar o Comitê de Ética em Pesquisa (01246-000) -Av. Dr. Arnaldo, 455 - Instituto Oscar Freire - $1^{\circ}$ andar- tel: $3061-$ 8004, Fax: 3061-8004-E-mail:cep.fmusp@hcnet.usp.br. É garantida a liberdade da retirada de seu consentimento a qualquer momento e consequentemente deixar de participar do estudo. As informações obtidas serão analisadas em conjunto com as de outras pessoas, não sendo divulgada a identificação de nenhum participante. Ao final do estudo, os resultados serão entregues as cooperativas e poderão ser disponibilizados para consulta através dos meios de divulgação científica. Você não terá despesas pessoais em qualquer fase do estudo e também não haverá compensação financeira relacionada à sua participação. Embora não haja nenhuma garantia de que você terá benefícios com sua participação, as informações serão úteis para diagnosticar a condição atual do trabalho nas cooperativas de materiais recicláveis. Os pesquisadores se comprometem a utilizar os dados e o material coletado somente para esta pesquisa.

\section{DECLARAÇÃo}

Eu informei a um dos pesquisadores do grupo sobre a minha decisão em participar nesse estudo.

Ficaram claros para mim quais são os propósitos do estudo, os procedimentos a serem realizados, seus desconfortos e riscos, a garantia de confidencialidade e de esclarecimentos permanentes. Ficou claro também que minha participação não tem despesas. Concordo voluntariamente em participar deste estudo e poderei retirar o meu consentimento a qualquer momento, antes ou durante o mesmo, sem penalidades, prejuízo ou perda de qualquer benefício que eu possa ter adquirido.

(Somente para o responsável do projeto)

Declaro que obtive de forma apropriada e voluntária o Consentimento Livre e Esclarecido deste cooperado para a participação neste estudo. 


\section{ANEXO III}

\section{PARECER}

Aluna: Marcia Cristina Castanhari Mandelli

Orientador: Nelson da Cruz Gouveia

Título: Condições de trabalho dos catadores de materiais recicláveis em cooperativas da região metropolitana de São Paulo

O presente projeto de pesquisa objetiva "avaliar a morbidade referida para distúrbios osteomusculares em catadores de Cooperativas de Materiais Recicláveis da Região Metropolitana de São Paulo". Trata-se de uma investigação epidemiológica baseada em inquérito padronizado sobre a ocorrência e a caracterização de sintomas osteomusculares nos últimos 12 meses entre 250 catadores vinculados a quatro Cooperativas de Materiais Recicláveis da Região Metropolitana de São Paulo. A coleta de dados será realizada por meio de entrevistas, fotografias e aplicação do Questionário Nórdico de Sintomas Musculoesqueléticos. Os dados serão submetidos a análise exploratória por meio de tabelas de frequência simples e gráficos descritivos. Todos os participantes da pesquisa deverão concordar e assinar Termo de Consentimento Livre e Esclarecido.

Após o exame cuidadoso do protocolo apresentado, não foi verificada qualquer tipo de restrição ética à presente investigação, atendendo a todas as exigências cabíveis em estudos dessa natureza. Sendo assim, recomendo aprovação do projeto pelo Conselho do Departamento de Medicina Preventiva para fins de encaminhamento à CEP/FMUSP.
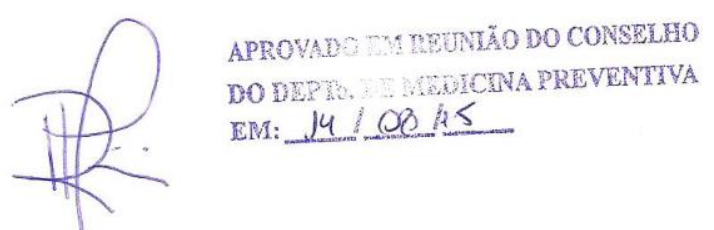

Prof. Dr. Ricardo Rodrigues Teixeira

Departamento de Medicina Preventiva da FMUSP

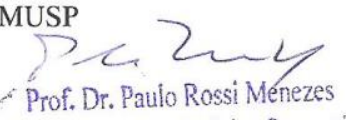

$<$ Prof. Dr. Paulo Rossi Menezes

Chefe do Depto. de Medicina Preventiva FMUSP 

9. Referências 



\section{Referências}

Abrelpe - Associação Brasileira de Empresas de Limpeza Pública e Resíduos Especiais. Panorama de Resíduos Sólidos no Brasil [online]. São Paulo: Abrelpe; 2013 [citado jan. 2015]. Disponível em: http://www.abrelpe.org.br/Panorama/panorma2013.pdf

Abrelpe - Associação Brasileira de Empresas de Limpeza Pública e Resíduos Especiais. Panorama de Resíduos Sólidos no Brasil [online]. São Paulo: Abrelpe; 2014 [citado fev. 2014]. Disponível em: http://www.abrelpe.org.br/Panorama/panorama2014.pdf

Abreu EP. Condições de trabalho, saúde e hábitos de vida dos catadores de resíduos sólidos da Vila Vale do Sol em Aparecida de Goiânia, GO [dissertação]. Goiânia: Pontifícia Universidade Católica de Goiás; 2011.

Alencar MCB, Cardoso CCO, Antunes MC. Condições de trabalho e sintomas relacionados à saúde de catadores de materiais recicláveis em Curitiba. Rev. Ter. Ocup. Univ. São Paulo. 2009; 20(1):36-42.

Alexandrino DFL, Ferreira MEC, Lima CL, Makkai LFC. Proposta de inclusão social e melhoria da qualidade de vida e saúde dos catadores e catadoras de materiais recicláveis de Viçosa - MG através da atividade física. Fit Perf J. 2009; 8(2):115-22.

Almeida JR, Elias ET, Magalhães MA, Vieira AJD. Efeito da idade sobre a qualidade de vida e saúde dos catadores de materiais recicláveis de uma associação em Governador Valadares, Minas Gerais, Brasil. Cien Saude Colet. 2009; 14(6):2169-80. [citado out. 2016]. Disponível em: http://search.proquest.com/openview/a86282db27cc55c94ad938e006b730c4/1. pdf?pq-origsite $=$ gscholar $\&$ cbl $=2034998$

Anjos LA, Ferreira J. A avaliação da carga fisiológica de trabalho na legislação brasileira deve ser revista! O caso da coleta de lixo domiciliar. Cad de Saúde Pública. 2000;16:785-790.

Associação Brasileira de Normas Técnicas. NBR 8849/1985: Apresentação de projetos de aterros controlados de resíduos sólidos urbanos. Rio de Janeiro; 1985.

Associação Brasileira de Normas Técnicas. NBR 8419/1992: Apresentação de projetos de aterros sanitários de resíduos sólidos urbanos. Rio de Janeiro; 1992.

Associação Brasileira de Normas Técnicas. NBR 15849/2010: Aterros sanitários de pequeno porte - Diretrizes para localização, projeto, implantação, operação e encerramento. Rio de Janeiro; 2010. 
Associação Brasileira de Normas Técnicas. NBR 10004/2004: Resíduos sólidos - classificação. Rio de Janeiro: ABNT; 2004.

Batista FGA, Lima VLA, Silva MMP. Avaliação de riscos físicos e químicos no trabalho de catadores de materiais recicláveis - Campina Grande, Paraîba. Revista Verde de Agroecologia e Desenvolvimento Sustentável. 2013; 8(2):284-290.

Bazo ML, Sturion L, Probst VS. Caracterização do reciclador da ONG RRV em Londrina Paraná. Fisioter. Mov. [online]. 2011; 24(4):613-620. [citado nov. 2012]. Disponível em: http://www.scielo.br/pdf/fm/v24n4/04.pdf

Bernardino DCAM, Andrade M. O Trabalho informal e as repercussões para a saúde do trabalhador: uma revisão integrativa. Rev. Enf. Ref. 2015; 4(7):149158.

Besen GR, Ribeiro H, Gunther WMR, Jacobi PR. Coleta seletiva na Região Metropolitana de São Paulo:impactos da Política Nacional de Resíduos Sólidos. Ambiente \& Sociedade [online]. 2014; 17(3):259-278. Disponível em: http://www.scielo.br/pdf/asoc/v17n3/en_v17n3a15.pdf

Bosi AP. A organização capitalista do trabalho "informal": o caso dos catadores de recicláveis. Revista Brasileira de Ciências Sociais [online]. 2008; 23(67):10216. [citado dez. 2015]. Disponível em: http://www.scielo.br/pdf/rbcsoc/v23n67/08.pdf

Brasil. Constituição da República Federativa do Brasil de 1988 [online]. [citado 15 jun. 2009]. Disponível em: http://www.planalto.gov.br/CCIVIL_03/CONSTITUICAO/CONSTITUICAO.HTM

Brasil. Decreto n. 5.940 de 25 de outubro de 2006. Institui a separação dos resíduos recicláveis descartados pelos órgãos e entidades da administração pública federal direta e indireta, na fonte geradora, e a sua destinação às associações e cooperativas dos catadores de materiais recicláveis [online]. [citado 18 fev. 2017]. Disponível [em: http://www.planalto.gov.br/ccivil_03/_Ato2004-2006/2006/Decreto/D5940.htm

Brasil. Decreto n. 7.404 de 23 de dezembro de 2010. Regulamenta a Lei no 12.305, de 2 de agosto de 2010, que institui a Política Nacional de Resíduos Sólidos, cria o Comitê Interministerial da Política Nacional de Resíduos Sólidos e o Comitê Orientador para a Implantação dos Sistemas de Logística Reversa. Diário Oficial da União, Brasilia (DF). 2010a 23 dez.; Seção 1:1 (Edição Extra).

Brasil. Decreto n. 7.405, de 23 de dezembro de 2010. Institui o Programa Pró-Catador, denomina Comitê Interministerial para Inclusão Social e Econômica dos Catadores de Materiais Reutilizáveis e Recicláveis o Comitê Interministerial da Inclusão Social de Catadores de Lixo criado pelo Decreto de 11 de setembro de 2003, dispõe sobre sua organização 
e funcionamento. Diário Oficial da União, Brasilia (DF). 2010b 23 dez.; Seção 1:7 (Edição Extra).

Brasil. Lei n. 5.764 de 16 de dezembro de 1971. Define a Política Nacional de Cooperativismo, institui o regime jurídico das sociedades cooperativas. [online]. [citado 8 jan. 2016]. Disponível em: http://www.planalto.gov.br/ccivil_03/LEIS/L5764.htm

Brasil. Lei n. 10.741 de $1^{\circ}$ de outubro de 2003. Dispõe sobre o Estatuto do Idoso [online]. [citado 2 jul. 2016]. Disponível em: http://www.planalto.gov.br/ccivil_03/leis/2003/L10.741.htm

Brasil. Lei n. 12.305 de 2 de agosto de 2010. Institui a Política Nacional de Resíduos Sólidos; altera a Lei no 9.605, de 12 de fevereiro de 1998. Diário Oficial da União [online]. Brasília (DF); 2010c 03 ago. Seção 1:3.[citado 30 out. 2011]. Disponível em: http://www.planalto.gov.br/ccivil_03/ ato20072010/2010/lei/l12305.htm

Brasil. Lei n.12.690 de 19 de julho de 2012. Dispõe sobre a organização e o funcionamento das Cooperativas e Trabalho; institui o Programa Nacional de Fomento às Cooperativas de Trabalho - PRONACOOP; e revoga o parágrafo único do art. 442 da Consolidação das Leis do Trabalho - CLT, aprovada pelo Decreto-Lei n. 5.452, de $1^{0}$ de maio de 1943[online]. [citado fev. 2017]. Disponível em:http://www.planalto.gov.br/ccivil_03/_Ato20112014/2012/Lei/L12690.htm

Brasil. Ministério do Meio Ambiente, ICLEI - Governos Locais pela Sustentabilidade. Plano de Gestão de Resíduos Sólidos: manual de orientação: apoiando a implementação da Política Nacional de Resíduos Sólidos: do nacional ao local. Brasilia: s.n.; 2012. Disponível em: http://www.mma.gov.br/estruturas/182/_arquivos/manual_de_residuos_solidos3 003_182.pdf

Brasil. Ministério do Meio Ambiente. Ministérios das Cidades. Elementos para organização da coleta seletiva e projeto dos galpões de triagem [online]. 2008. [citado 10 jan. 2014]. Disponível em http://www.mma.gov.br/estruturas/srhu_urbano/_publicacao/125_publicacao200 12011032243.pdf

Brasil. Ministério do Meio Ambiente. Política de Resíduos Sólidos apresenta resultados em 4 anos [online]. [2012]. Disponível em: http://www.mma.gov.br/informma/item/10272-pol\%C3\%ADtica-deres\%C3\%ADduos-s\%C3\%B3lidos-apresenta-resultados-em-4-anos

Brasil. Ministério do Meio Ambiente. Sistema Nacional de Informações sobre a Gestão dos Resíduos Sólidos - SINIR. Planos municipais de gestão integrada de resíduos sólidos [online]. [2016]. Disponível em: 
http://www.sinir.gov.br/web/guest/2.5-planos-municipais-de-gestao-integradade-residuos-solidos

Brasil. Ministério do Trabalho e Emprego. Classificação Brasileira de Ocupações (CBO). 3a. ed. Brasîlia: s.n.; 2010. (Códigos, títulos e descrições; Livro 1). [citado 4 set. 2010]. Disponível em: http://www.mtecbo.gov.br/cbosite/pages/Downloads

Brasil, Ministério do Trabalho e Emprego. Norma Regulamentadora $n^{\circ}$ 11: Transporte, movimentação, armazenagem e manuseio de materiais; 2004. [citado 13 fev. 2015]. Disponível em: http://trabalho.gov.br/images/Documentos/SST/NR/NR11.pdf

Brasil. Ministério do Trabalho e Previdência Social. Manual de aplicação da Norma Regulamentadora n. ${ }^{\circ}$ 17. Brasilia; 2002. [citado 20 mar. 2010]. Disponível em: http://trabalho.gov.br/images/Documentos/SST/NR/NR17.pdf

Brasil. Senado Federal. Parecer n. 385, de 2015. Redação final do Projeto de Lei do Senado n. 425, de 2014 [que prorroga o prazo para a disposição final ambientalmente adequada dos rejeitos de que trata o art. 54 da Lei $n^{0} 12.305$, de 2 de agosto de 2010, consolidando a Emenda $n^{\circ} 1$ 1]. Diário do Senado Federal [online]. 20152 jul, n.102:292-294. [citado fev. 2017]. Disponível em: http://legis.senado.leg.br/diarios/BuscaDiario?tipDiario=1\&datDiario=02/07/2015 \&paginaDireta $=00282$

Burgos, R. Periferias urbanas da metrópole de São Paulo: territórios da base da indústria da reciclagem no urbano periférico [tese]. São Paulo: Faculdade de Filosofia, Letras e Ciências Humanas, Universidade de São Paulo; 2009.

Calderoni S. Os bilhões perdidos no lixo. 3a ed. São Paulo: Humanitas; 1999.

Calia RG, Vieira MSR. Incapacidade e dor crônica. In: Andrade Filho ACC. Dor: diagnóstico e tratamento. São Paulo: Roca, 2001. Cap. 5, p.63-73.

Campos HKT. Centro de desenvolvimento sustentável, resíduos sólidos e sustentabilidade: o papel das instalações de recuperação [dissertação]. Brasilia: Universidade de Brasilia; 2013.

Carranza AC, Zelaya L, Iglesias S. El Salvador: trabajo infantil en los basureros: una evaluación rápida. Geneve: Oficina Internacional del Trabajo; 2002.

Castilhos Junior AB, Ramos NF, Alves CM, Forcellini FA, Graciolli OD. Catadores de materiais recicláveis: análise das condições de trabalho e infraestrutura operacional no Sul, Sudeste e Nordeste do Brasil. Cien Saude Colet. [online].2013;18(11):3115-3124. Disponível em: http://www.redalyc.org/pdf/630/63028795002.pdf 
Cavalcante LPS, Silva MMP, Lima VLA. Análise comparativa de riscos ergonômicos e de acidentes que envolvem catadores de materiais recicláveis organizados e informais. In: Anais do $V$ Congresso Brasileiro de Gestão Ambiental [online]. 24 a 27 de novembro de 2014. Belo Horizonte, Brasil. 2014;5. [citado fev. 2017]. Disponível em: http://www.ibeas.org.br/congresso/Trabalhos2014/III-038.pdf

Cavalcante S, Franco MFA. Profissão perigo: percepção de risco à saúde entre os catadores do Lixão do Jangurussu. Revista Mal-estar e Subjetividade. 2007;7(1):211-231. [citado 15 jan. 2010]. Disponível em: http://www.unifor.br/joomla/images/pdfs/pdfs_notitia/1787.pdf

CEADEC - Centro de Estudos ao Apoio ao Desenvolvimento Emprego e Cidadania. Escritório Nacional do Cataforte III. Comercialização em rede e inter redes, beneficiamento e verticalização da cadeia de resíduos sólidos: um guia para organização das Redes de catadores e catadoras de materiais recicláveis, Fev. 2017. [citado em 04 jul. 2017] Disponível em: http://www.ceadec.org.br/arquivos/publicacoes-11-CATAFORTE_Guia_Comercializacao_Completo.pdf

Collins $\mathrm{CH}$, Kennedy DA. The microbiological hazards of municipal and clinical wastes. J Appl Microbiol. 1992;73(1):1-6.

Companhia de Tecnologia de Saneamento Ambiental. Inventário Estadual de Resíduos Sólidos Urbanos- 2012. São Paulo: CETESB; 2013.

Conceição JTP, Conceição MM, Araújo PSL. Obsolescência programada: tecnologia a serviço do capital. INOVAE: Journal of Engineering and Technology Innovation. 2014;2(1):90-105. [citado 21 fev. 20171. Disponível em: http://www.revistaseletronicas. fmu.br/index.php/inovae/article/view/386/548

Cordeiro IA, Rosa JL, Ferreira JD, Gorni LF, Ribeiro RB. Avaliação da cadeia de suprimentos no processo de triagem de materiais recicláveis: estudo de caso. In: XII Encontro Latino Americano de Iniciação Científica, IX Encontro Latino Americano de Pós-Graduação; 2008.

Costa D, Lacaz FAC; Jackson Filho JM, Vilela RAG. Saúde do trabalhador no SUS: desafios para uma política pública. Rev Bras Saude Ocup. 2013; 38 (127):11-30.

Costa DO, Tambellini AT. A visibilidade dos escondidos. Physis. 2009; 19(4):953-968. [citado out. 2016]. Disponível em: http://www.scielo.br/scielo.php?script=sci_arttext\&pid=S0103$73312009000400003 \&$ lng=pt\&nrm=iso\&tlng=pt

Couto HA, Nicoletti SJ, Lech O. Gerenciando a LER e os DORT nos tempos atuais. 1a ed. Belo Horizonte: Ed. Minas Gerais/Editora Ergo; 2007. p.19-39: Entendendo os membros superiores e a sobrecarga relacionada ao trabalho. 
Dall'Agnol CM, Fernandes FS. Saúde e autocuidado entre catadores de lixo: vivências no trabalho em uma cooperativa de lixo reciclável. Ver LatAm Enfermagem[online]. 2007; 15(n. especial):729-735. [citado 10 mar. 2010]. Disponível em: http://www.scielo.br/pdf/rlae/v15nspe/pt_02.pdf

Dejours, Christophe. A Loucura do Trabalho,estudo de psicopatologia do trabalho. 3a ed. São Paulo: Cortez Editora, 1988.

Egri D. Ler (Dort). Rev Bras de Reumatol.1999;39(2):98-106.

Fabris S, Freire MTA, Reves FG. Embalaqens plásticas: tipos de materiais, contaminação de alimentos e aspectos de legislação. Revista Brasileira de Toxicologia. 2006; 19(2):59-70.

Ferreira JA. Lixo hospitalar e domiciliar: semelhanças e diferenças: estudo de caso no município do Rio de Janeiro [tese]. Rio de Janeiro: Fundação Oswaldo Cruz; 1997.

Ferreira JA, Anjos LA. Aspectos de saúde coletiva e ocupacional associado à gestão de resíduos sólidos municipais. Cad Saude Publica. 2001; (17)3:689696.

Ferron MM. Saúde, trabalho e meio ambiente: exposição a metais em catadores de materiais recicláveis [tese] São Paulo: Faculdade de Medicina, Universidade de São Paulo; 2015.

Fundacentro. Introdução à higiene ocupacional. São Paulo: Ministério do Trabalho/Fundacentro; 2004. Cap. 1, p. 12-13: Histórico da higiene ocupacional

Gonçalves-Dias SLF. Catadores: uma perspectiva de sua inserção no campo da indústria da reciclagem [tese]. São Paulo: Universidade de São Paulo, Programa de Pós-Graduação em Ciência Ambiental; 2009.

Gouveia N. Resíduos Sólidos Urbanos: impactos socioambientais e perspectiva de manejo sustentável com inclusão social. Cien Saude Colet. 2012; 17(6):1503-1510.

Grimberg E, coordenação. Coleta seletiva com inclusão dos catadores. Fórum Lixo e Cidadania na Cidade de São Paulo. Experiência e desafios. São Paulo: Pólis; 2007. (Publicações Polis; 49). [citado 2007]. Disponível em: http://www.polis.org.br/uploads/1008/1008.pdf

Guérin F, Laville A, Daniellou F, Duraffourg J, Kerguelen A. Compreender o trabalho para transformá-lo: a prática da ergonomia. 3a ed. São Paulo: Fundação Vanzolini/Editora Edgard Blücher; 2006.

Gutberlet J, Baeder AM. Informal recycling and occupational health in Santo André, Brazil. Int J Environ Health Res. 2008;18(1):1-15. [citado out. 2016]. Disponível em: http://www.informaworld.com/smpp/title $\sim$ content=t713425582 
Gutberlet J, Baeder AM, Pontuschka NN, Felipone SMN, Santos TLF, Souza MAS. Pesquisa-ação em educação ambiental e saúde dos catadores: estudo de caso realizado com integrantes de cooperativas de coleta seletiva e reciclagem na região metropolitana de São Paulo. In: Pereira BCJ, Goes FL. Catadores de materiais recicláveis: um encontro nacional. Rio de Janeiro: IPEA; 2016. Cap. 8, p. 201-214.

Hoefel MG, Carneiro FF, Santos LMP, Gubert MB, Amate EM, Santos W. Acidentes de trabalho e condições de vida de catadores de resíduos sólidos recicláveis no lixão do Distrito Federal. Rev Bras Epidemiol.2013;16(3):764-85.

Hoornweg D, Bhada-Tata P. What a waste: A Global Review of Solid Waste Management [online]. Washington: World Bank; 2012a. (Urban Development Series - Knowledge papers).

Hoornweg D, Bhada-Tata P. What a waste: A Global Review of Solid Waste Management [online]. Washington: World Bank; 2012b. (Urban Development Series - Knowledge papers). Capítulo 3, p. 8 - 12: Waste generation. [citado nov. 2015]. Disponível em: http://siteresources.worldbank.org/INTURBANDEVELOPMENT/Resources/336 387-1334852610766/Chap3.pdf

Instituto Brasileiro de Geografia e Estatística. Perfil dos municípios brasileiros: 2012: pesquisa de informações básicas municipais. Rio de Janeiro: IBGE; 2013a. [citado 19 ago. 2016]. Disponível em: http://biblioteca.ibge.gov.br/visualizacao/livros/liv64638.pdf

Instituto Brasileiro de Geografia e Estatística. Síntese dos indicadores sociais: uma análise das condições de vida da população brasileira: 2013. Rio de Janeiro: IBGE; 2013b. (Estudos e Pesquisas. Informação Demográfica e Socioeconômica; 32). Disponível em: http://biblioteca.ibge.gov.br/visualizacao/livros/liv66777.pdf

Instituto de Pesquisa Econômica Aplicada. Plano Nacional de Resíduos Sólidos: diagnóstico dos resíduos urbanos, agrosilvopastoris e a questão dos catadores. [Brasília]: IPEA; 2012. (Comunicados do IPEA; 145). [citado jan. 2015]. Disponível em:

http://www.ipea.gov.br/portal/images/stories/PDFs/comunicado/120425_comuni cadoipea0145.pdf

Instituto de Pesquisa Econômica Aplicada. Situação social das catadoras e dos catadores de material reciclável e reutilizável: Brasil. Brasilia: Ipea; 2013. [citado fev. 2016]. Disponível em: file:///C:/Users/USUARIO/Downloads/Catadores\%20de\%20materiais\%20recicl \%C3\%A1veis_um\%20encontro\%20nacional.pdf 
Jacobi PR, Besen GR. Gestão de resíduos sólidos em São Paulo: desafios da sustentabilidade. Estudos avançados. 2011;25(71):135-158. [citado out. 2016]. Disponível em: http://dx.doi.org/10.1590/S0103-40142011000100010

Jesus MCP, Santos SMR, Abdalla JGF, Jesus PBR, Alves MJM, Teixeira N, Jesus RR, Vilela MMP, Mattos LR. Avaliação da qualidade de vida de catadores de materiais recicláveis. Rev. Eletr. Enf. [online]. 2012;14(2):277-85. [citado 24 fev. 2014]. Disponível em: http://dx.doi.org/10.5216/ree.v14i2.15259.

Kompier M, Levi L. Stress at work: causes, effect and prevention: a guide for small and medium sized enterprises. Dublin: European Foundation for the Improvement of Living and Working Conditions; 1994.

Kuorinka I, Forcier L, editors. Work-related musculoskeletal disorders (WMSDs): a reference book for prevention. GreatBritain: Taylor \& Francis; 1995.

Lajolo RD, coordenador técnico. Cooperativa de Catadores de Materiais Recicláveis: guia para implantação. São Paulo: IPT/Sebrae; 2003a.

Lajolo RD, coordenador técnico. Cooperativa de Catadores de Materiais Recicláveis: guia para implantação. São Paulo: IPT/Sebrae; 2003b. Cap. 3, p. 65-75: Implantação de uma cooperativa.

Lavoie J, Guertin S. Evaluation of health and safety risks in municipal solid waste recycling plants. J Air Waste Manage Assoc. 2001;51:352-360.

Levy PS, Lemeshow S. Sampling for health professionals. Belmont: LLP; 1980.

Maccarini AC, Hernández RC. Melhoria no processo de triagem de materiais recicláveis a partir da implementação de tecnologias simples. Rev. Syn. Scy. 2007;2:1- 4. [Universidade Tecnológica Federal do Paraná].

Maciel RH. Prevenção da LER/DORT: o que a ergonomia pode oferecer. São Paulo: Instituto Nacional de Saúde no Trabalho; 2000. (Cadernos de Saúde do Trabalhador). [citado 21 fev. 2017]. Disponível em: http://www.coshnetwork.org/sites/default/files/caderno9\%20ler-dort.pdf

Madruga RB. Cargas de trabalho encontradas nos coletores de lixo domiciliar: um estudo de caso [dissertação]. Florianópolis: Universidade Federal de Santa Catarina, Programa de Pós-Graduação em Engenharia de Produção; 2002.

Mandeli MCC,Roland MIF, Souza GF,Germani ACCG, Gouveia N, GonçalvesDias SLF. "Catando e reciclando saúde": relatos do $1^{\circ}$ Encontro Universidade Movimento Nacional de Catadores de Recicláveis. Cadernos Gestão Social. 2013; 4(2):285-95. [citado dez. 2016]. Disponível em http://www.periodicos.adm.ufba.br/index.php/cgs/article/view/360/pdf_63 
Medeiros LFR, Macedo KB. Profissão: catador de material reciclável, entre o viver e o sobreviver. Revista Brasileira de Gestão e Desenvolvimento Regional. 2007;3(2):72-94. [citado out. 2016]. Disponível em: http://www.rbgdr.net/022007/artigo4.pdf

Ministério da Saúde. Secretaria de Vigilância em Saúde. Departamento em Saúde Ambiental e Saúde do Trabalhador. Dor relacionada ao trabalho: Lesões por Esforços Repetitivos (LER): Distúrbios Osteomusculares Relacionados ao Trabalho (DORT). Brasilia: Editora MS; 2012. (Série A. Normas e Manuais Técnicos. Saúde do Trabalhador, Protocolos de Complexidade Diferenciada; 10) [online]. [citado 3 mar. 2014]. Disponível em : http://bvsms.saude.gov.br/bvs/publicacoes/dor_relacionada_trabalho_ler_dort.p df

Ministério do Desenvolvimento Social e Combate à Fome. Movimento Nacional de Catadores de Materiais Recicláveis. Análise do custo de geração de postos de trabalho na economia urbana para o segmento dos catadores de materiais recicláveis. Relatório técnico final. Jan. 2006.

Moura, AASBF. Riscos ambientais à saúde ocupacional do catador de recicláveis em Goiânia [dissertação]. Goiânia: Pontifícia Universidade Católica de Goiás, Programa de Pós-Graduação em Ciências Ambientais e Saúde; 2010.

Mucelin CA, Bellini M. Lixo e impactos ambientais perceptíveis no ecossistema urbano. Sociedade \& Natureza. 2008;20(1):111-124.

Mussi G. Prevalência de distúrbios osteomusculares relacionados ao trabalho (LER/DORT) em profissionais cabeleireiras de institutos de beleza de dois distritos da cidade de São Paulo [tese]. São Paulo: Faculdade de Medicina, Universidade de São Paulo; 2005.

NIOSH - National Institute for Occupational Safety and Health. Book: A Critical Review of Epidemiologic Evidence for Work-Related Musculoskeletal Disorders of the Neck, Upper Extremity, and Low Back, p. 1-1 até 7-11, Publications Dissemination 4676 Columbia Parkway Cincinnati, OH 45226-1998. U.S. DEPARTMENT OF HEALTH AND HUMAN SERVICES Public Health Service Centers for Disease Control and Prevention National Institute for Occupational Safety and Health July 1997, Book : https://www.cdc.gov/niosh/docs/97141/pdfs/97-141.pdf

OCB - Organização das Cooperativas Brasileiras, realização. O que muda com a Lei $n^{\circ}$ 12.690/2012: cooperativismo de trabalho. 2012. Disponível em: http://cicopamercosur.coop/wp-content/uploads/2014/11/BRASIL-Cartilla-sobrela-LEY-12690-OCB.pdf

OIT - Organização Internacional do Trabalho - OIT. Cooperativas: mudanças, oportunidades e desafios. Brasilia: OIT; 2001. p. 94-97. [citado 15 fev. 2017]. Disponível

em: 
http://www.oit.org.br/sites/default/files/topic/cooperative/pub/cooperativas_muda ncas_oportunidades_desafios_219.pdf

Oliveira FG. Processo de trabalho e produção de vínculos sociais: eficiência e solidariedade na triagem de materiais recicláveis [dissertação]. Belo Horizonte: Universidade Federal de Minas Gerais, Programa de Pós-Graduação em Engenharia de Produção; 2010.

Parra ARC, Lima C, Felipone SMN, Santos SS, Dotte MS; André LIA, Abreu AMPM, Santos TLF. Relatório preliminar: condições de trabalho na Cooperativa de Material Reciclável Miguel Yunes. São Paulo; novembro de 2015. [citado out. 2016]. Disponível em: http://www.nrcomentada.com.br/download/relatorios/4Relat\%C3\%B3rio\%20Co opeerativa\%20Miguel\%20Yunes.pdf

Pinheiro FA, Tróccoli BT, Carvalho CV. Validação do questionário nórdico de sintomas osteomusculares como medida de morbidade. Rev Saude Publica. 2002;36(3):307-312. [citado 1 maio 2012]. Disponível em: http://www.fsp.usp.br/sp

Pinhel JR, organizador. Do lixo à cidadania: guia para formação de cooperativas de catadores de materiais recicláveis. São Paulo: Peirópolis, 2013, p. 16-242.

Porto MFS, Juncá DCM, Gonçalves RS, Filhote MIF. Lixo, trabalho e saúde: um estudo de caso com catadores em um aterro metropolitano no Rio de Janeiro, Brasil. Cad Saude Publica. 2004;20(6):1.503-1.514. [citado 20 dez. 2009]. Disponível em: http://www.scielo.br/pdf/csp/v20n6/07.pdf

Rego MAV, Mendonça ACO, Sá ACS, Lopes DMC, Moura FP, Alcântara TQN. Saúde do trabalhador nos Congressos Brasileiros de Epidemiologia. Revista Baiana de Saúde Pública. 2005;29(1):69-79.

Ribeiro H, Besen GR. Panorama da coleta seletiva no Brasil: desafios e perspectivas a partir de três estudos de caso. Revista de Gestão Integrada em Saúde do Trabalho e Meio Ambiente. 2007;2(4):1-18.

Rodrigues C. À procura de alternativas econômicas em tempos de qlobalização: o caso das cooperativas de recicladores de lixo na Colômbia. In: Santos BS, organizador. Produzir para viver: os caminhos da produção não capitalista. 2a ed. Rio de Janeiro: Civilização Brasileira; 2004. p.329-368.

Rothman KJ, Greenland S, Lash TL. Modern Epidemiology. 3a ed. Philadelphia, PA: Wolters Kluwer, Lippincott Williams \& Wilkins; 2009. p. 97: Study Desing and Conduct, Types of Epidemiologic Studies.

São Paulo (Cidade). Comitê Intersecretarial para a Política Municipal de Resíduos Sólidos. Plano de Gestão Integrada de Resíduos Sólidos da Cidade de São Paulo. São Paulo: Prefeitura do Município de São Paulo; 2014. 
Disponível em: http://www.prefeitura.sp.gov.br/cidade/secretarias/upload/servicos/arquivos/PGI RS-2014.pdf

São Paulo (Cidade). Decreto n. 42.290 de 15 de agosto de 2002.Institui o Programa Socioambiental Cooperativa de Catadores de Material Reciclável, e dá outras providências [online].Diário Oficial do Município de São Paulo, São Paulo. 200216 ago.; 47(154):1 [citado jun. 2017]. Disponível em:https://www.imprensaoficial.com.br/DO/BuscaDO2001Documento_11_4.as px?link=/2002/diario\%2520oficial\%2520do\%2520municipio/agosto/16 $/$ pag_000 1_F53R4BJOUT69GeF5TH0241ERI0B.pdf\&pagina $=1 \&$ data $=16 / 08 / 2002 \&$ cader no=Di\%C3\%A1rio\%200ficial\%20do\%20Munic\%C3\%ADpio\&paginaordenacao= 10001

São Paulo (Cidade). Decreto n. 48.799 de 9 de outubro de 2007. Confere nova normatização ao Programa Socioambiental Cooperativa de Catadores de Material Reciclável, altera a sua denominação para Programa Socioambiental de Coleta Seletiva de Resíduos Recicláveis e revoga o Decreto $n^{\circ} 42.290$, de 15 de agosto de 2002 [online]. [citado jun. 2017]. Disponível em: http://www3.prefeitura.sp.gov.br/cadlem/secretarias/negocios_juridicos/cadlem/i ntegra.asp?alt=16082002D\%20422900000\%20\%20\%20\%20\%20\%20\%20\%20 $\% 20 \% 20 \% 20 \% 20 \&$ secr $=5 \&$ depto=0\&descr_tipo=DECRETO

São Paulo (Cidade). Programa de Coleta Seletiva. [2016]. [online]. [citado 16 nov. 2016]. Disponível em: http://www.prefeitura.sp.gov.br/cidade/secretarias/regionais/amlurb/coleta_selet iva/index.php?p=4623

São Paulo (Estado). Secretaria do Meio Ambiente. Coletas seletivas para prefeituras: guia de implantação. 4a ed. São Paulo: SMA/CPLEA; 2005.

Silva MC, Fassa ACG, Domingues MR, Kriebel D. Gonalgia entre trabalhadores e fatores ocupacionais associados: uma revisão sistemática [review]. Cad Saude Publica. 2007; 23(8):1763-1775. [citado 9 nov. 2012]. Disponível em: http://www.scielo.br/scielo.php?script=sci_arttext\&pid=S0102-

$311 \times 2007000800003$

Silva MC, Fassa AG, Valle NCJ. Dor lombar crônica em uma população adulta do Sul do Brasil: prevalência e fatores associados. Cad Saude Publica. 2004; 20(2):377-385. Disponível em: http://www.scielo.br/scielo.php?script=sci_arttext\&pid=S0102311X2004000200005

Souza FL.Doenças musculoesqueléticasem catadores demateriais recicláveis do município de Matinhos/PR. Curitiba: Universidade Federal do Paraná; 2014. [Artigo apresentado ao Curso de Especialização em Medicinado Trabalho]

Souza GF. Avaliação ambiental nas cooperativas de materiais recicláveis [tese]. São Paulo: Faculdade de Medicina, Universidade de São Paulo; 2015. 
Tavares IAF. Do lixo à reciclagem: uma visão sobre o trabalho dos catadores e catadoras no município de Divinópolis [dissertação]. Divinópolis: Universidade do Estado de Minas Gerais, Programa em Educação, Cultura e Organizações Sociais; 2009.

Teixeira MJ, Teixeira WGJ, Santos FPS, Andrade DCA, Bezerra SL, Figueiró JB, Okada M. Epidemiologia clínica da dor musculoesquelética. Rev Med (São Paulo). 2001; 80(1, edição especial, parte 1):1-21.

Velloso MP, Santos EM, Anjos LA. Processo de trabalho e acidentes de trabalho em coletores de lixo domiciliar na cidade do Rio de Janeiro, Brasil. Cad Saude Publica. 1997;13 (4):693-700.

Velloso MP, Valadares JC, Santos EM. A coleta de lixo domiciliar na cidade do Rio de Janeiro: um estudo de caso baseado na percepção do trabalhador. Ciênc. Saúde Coletiva. 1998; 3(2):143-150.

Virgem MRC. Estudo dos riscos ocupacionais e percepções dos separadores de resíduos cooperados sobre o trabalho e a preservação ambiental [dissertação]. Aracaju: Universidade Tiradentes, Programa de Pós-graduação em Saúde e Ambiente; 2010.

Vital MHF, Ingouville M, Pinto MAC. Estimativa de investimentos em aterros sanitários para atendimento de metas estabelecidas pela Política Nacional de Resíduos Sólidos entre 2015 e 2019. BNDES Setorial. 2014; 40:43-92.[citado out. 2016]. Disponível em: https://web.bndes.gov.br/bib/jspui/bitstream/1408/3041/1/Estimativa\%20de\%20i nvestimentos\%20em\%20aterros\%20sanitarios_P.pdf 